\title{
Application of Hydrogeology and Tritium-Based Groundwater-Age Estimates to Assess the Travel Time of Groundwater at the Site of a Landfill to the Mahomet Aquifer near Clinton, Illinois
}

Scientific Investigations Report 2015-5159 



\section{Application of Hydrogeology and Tritium- Based Groundwater-Age Estimates to Assess the Travel Time of Groundwater at the Site of a Landfill to the Mahomet Aquifer near Clinton, Illinois}

By Robert T. Kay and Paul M. Buszka

With a section on Regional Indications of Recharge to the Mahomet Aquifer from Previously Collected Tritium and Pesticide Data

By Paul M. Buszka and William S. Morrow

Scientific Investigations Report 2015-5159 


\title{
U.S. Department of the Interior SALLY JEWELL, Secretary
}

\section{U.S. Geological Survey Suzette M. Kimball, Director}

\author{
U.S. Geological Survey, Reston, Virginia: 2016
}

For more information on the USGS - the Federal source for science about the Earth, its natural and living resources, natural hazards, and the environment—visit http://www.usgs.gov or call 1-888-ASK-USGS.

For an overview of USGS information products, including maps, imagery, and publications, visit http://www.usgs.gov/pubprod/.

Any use of trade, firm, or product names is for descriptive purposes only and does not imply endorsement by the U.S. Government.

Although this information product, for the most part, is in the public domain, it also may contain copyrighted materials as noted in the text. Permission to reproduce copyrighted items must be secured from the copyright owner.

Suggested citation:

Kay, R.T., and Buszka, P.M., 2016, Application of hydrogeology and groundwater-age estimates to assess the travel time of groundwater at the site of a landfill to the Mahomet Aquifer, near Clinton, Illinois, with a section on Regional Indications of Recharge to the Mahomet Aquifer from Previously Collected Tritium and Pesticide Data, by Buszka, P.M. and Morrow, W.S.: U.S. Geological Survey Scientific Investigations Report 2015-5159, 54 p., http:// dx.doi.org/10.3133/sir20155159.

ISSN 2328-0328 (online) 


\section{Contents}

Abstract

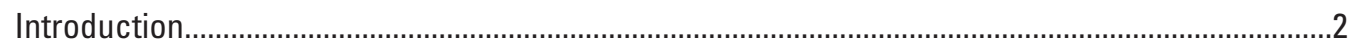

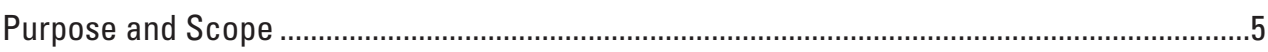

Regional Hydrogeologic Setting and Indications of Recharge to the Mahomet Aquifer

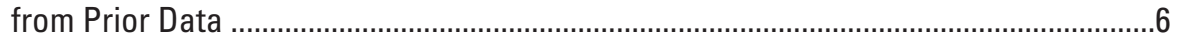

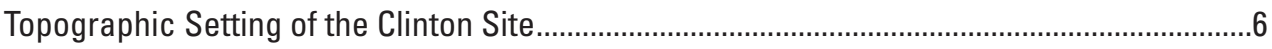

Methods of Data Collection and Analysis for the Clinton Site ...........................................................

Water Sample Collection at the Clinton Site .....................................................................

Laboratory Analysis of Groundwater Samples From the Clinton Site........................................

Interpretation of Recharge Using Tritium Data .................................................................10

Hydrogeology, Estimates of Groundwater Age, and Assessment of Groundwater Travel Time

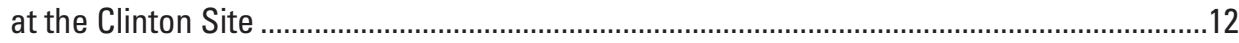

Hydrogeology and Estimates of Groundwater Age at the Clinton Site ..................................12

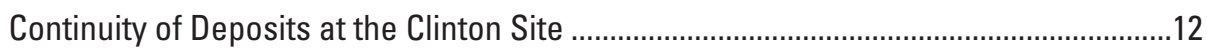

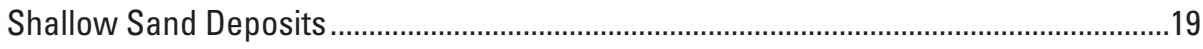

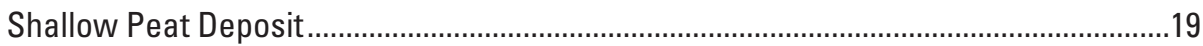

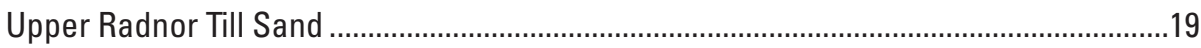

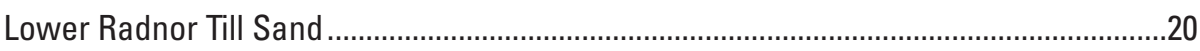

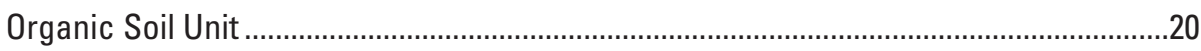

Glasford Formation Below the Organic Soil Unit and the Banner Formation Tills ..........21

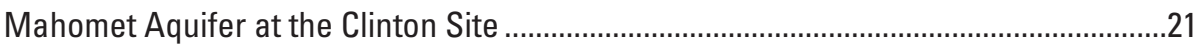

Two-Part Mixing Model Evaluation of Tritium-Based Groundwater Age Estimates

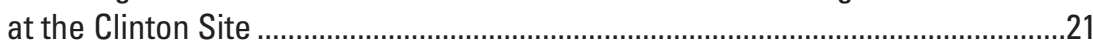

Assessment of the Groundwater Travel Time at the Site of the Proposed Chemical

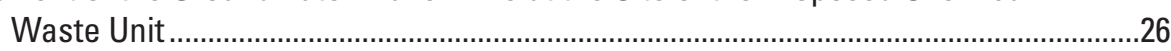

Vertical Groundwater Travel Time Estimated at the Clinton Site Using Tritium-Age Based Groundwater Velocity ................................................................................26

Vertical Groundwater Travel Time Using Estimates of Effective Porosity and Darcy Velocity.

Scenario One, Vertical Hydraulic Conductivity Equal to Geometric Mean of all Site Triaxial Permeability Tests

Scenario Two, Vertical Hydraulic Conductivity Equal to Geometric Mean of Site Triaxial Permeability Tests Above the Upper Radnor Till Sand and Below the Roxana Silt-Robein Silt Member.

Scenario Three, Vertical Hydraulic Conductivity Equal to Values for Tills of the Wedron Group and Glasford Formation from Regional Groundwater Flow

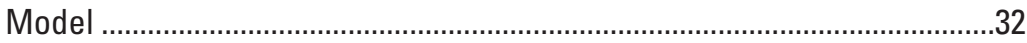

Scenario Four, Vertical Hydraulic Conductivity Equal to Value for Glasford Formation Tills From Regional Groundwater Flow Model ..........................33

Scenario Five, Vertical Hydraulic Conductivity Equal to Value for Banner Formation Tills from Regional Groundwater Flow Model ............................34

Summary of Hydrogeology and Recharge Interpretations from Clinton Site Data..................35 
Regional Indications of Recharge to the Mahomet Aquifer from Previously Collected

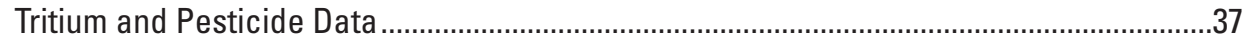

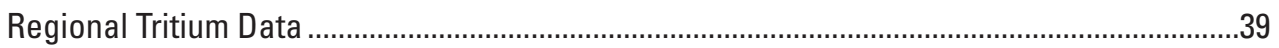

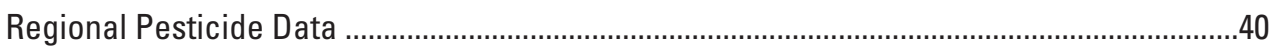

Indications of Regional Heterogeneity in Recharge to the Confined Part of the Mahomet

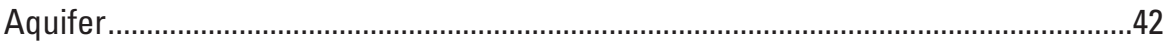

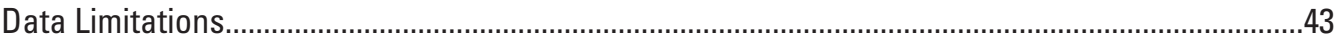

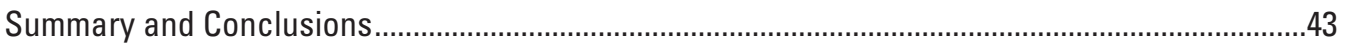

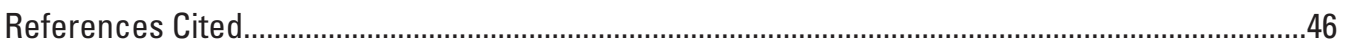

\section{Figures}

1. Map showing location of the Clinton site, near Clinton, Illinois .

2. Map showing location of solid waste units and sampled monitoring wells, Clinton site, near Clinton, Illinois

3. Map showing location of the Mahomet aquifer and selected bedrock valleys in eastcentral Illinois

4. Map showing well and boring locations and the elevations of sand deposits, within predominantly silt and clay deposits, and in the Mahomet aquifer in the vicinity of Clinton landfill unit \#3, near Clinton, Illinois

5. Graphs showing concentrations of tritium in precipitation and decay-corrected, annual average concentrations of tritium in precipitation, decay corrected to the date of sampling (May 16, 2012)

6. Graphs showing glacial stratigraphy of Quaternary-aged deposits and pertinent features beneath Clinton landfill unit \#3, near Clinton, Illinois

7. Map showing location of lines of geologic section, Clinton land fill unit \#3, near Clinton, Illinois

8. Geologic cross section showing line of geologic section $A-A^{\prime}$, Clinton landfill unit \#3, near Clinton, Illinois

9. Geologic cross section showing line of geologic section $B-B^{\prime}$, Clinton landfill unit \#3, near Clinton, Illinois

10. Geologic cross section showing line of geologic section $C-C^{\prime}$, Clinton landfill unit \#3, near Clinton, Illinois

11. Geologic cross section showing line of geologic section $D-D^{\prime}$, Clinton landfill unit \#3, near Clinton, Illinois

12. Graphs showing mixing computations indicating differences and similarities between tritium in the sample from well G53S in the vicinity of Clinton landfill unit \#3, near Clinton, Illinois and hypothetical mixtures of pre-1953 recharge and 1953-2002 recharge.

13. Conceptual diagram of features and data used in the solution of the Darcy velocity equation according to scenario one for the deposits at Clinton landfill unit \#3, near Clinton, Illinois.

14. Conceptual diagram of features and data used in the solution of the Darcy velocity equation according to scenario two for the deposits at Clinton landfill unit \#3, near Clinton, Illinois

15. Conceptual diagram of features and data used in the solution of the Darcy velocity equation according to scenario three for the deposits at Clinton landfill unit \#3, near Clinton, Illinois 
16. Conceptual diagram of features and data used in the solution of the Darcy velocity equation according to scenario four for the deposits at Clinton landfill unit \#3, near Clinton, Illinois

17. Conceptual diagram of features and data used in the solution of the Darcy velocity equation according to scenario five for the deposits at Clinton landfill unit \#3, near Clinton, Illinois

18. Maps showing locations of domestic wells in regional Mahomet aquifer network in east-central Illinois that previously were sampled by the U.S. Geological Survey for pesticide and tritium concentrations, 1996-2011

\section{Tables}

1. Well data and results of tritium analyses, Clinton site, near Clinton, Illinois, May 16, 2012.

2. Estimates of effective porosity computed using the Darcy velocity equation with a tritium-based vertical groundwater velocity and vertical hydraulic conductivity values from the Clinton site, near Clinton, Illinois and from Roadcap and others (2011).

3. Estimates of vertical groundwater velocity and groundwater travel time for the Clinton site, near Clinton, Illinois by solution of the Darcy velocity equation using selected values of vertical hydraulic conductivity and equivalent porosity from scenarios in table 2 and vertical hydraulic conductivity from Roadcap and others (2011).

4. Results of U.S. Geological Survey sampling from domestic wells open to the Mahomet aquifer in east-central Illinois, 1996 to 2011.

5. Minimum vertical groundwater flow velocities and maximum time of travel from land surface to the Mahomet aquifer for water samples collected by U.S. Geological Survey from domestic wells open to the Mahomet aquifer in eastcentral Illinois, 1996 to 2011, with detections of a pesticide and tritium-based groundwater age classification. 


\section{Conversion Factors}

\begin{tabular}{|c|c|c|}
\hline Multiply & By & To obtain \\
\hline \multicolumn{3}{|c|}{ Length } \\
\hline foot $(\mathrm{ft})$ & 0.3048 & meter $(\mathrm{m})$ \\
\hline mile (mi) & 1.609 & kilometer $(\mathrm{km})$ \\
\hline \multicolumn{3}{|c|}{ Volume } \\
\hline gallon (gal) & 3.785 & liter $(\mathrm{L})$ \\
\hline \multicolumn{3}{|c|}{ Flow rate } \\
\hline foot per day (ft/d) & 0.3048 & meter per day $(\mathrm{m} / \mathrm{d})$ \\
\hline foot per year (ft/yr) & 0.3048 & meter per year (m/yr) \\
\hline \multicolumn{3}{|c|}{ Mass } \\
\hline ounce, avoirdupois (oz) & 28.35 & $\operatorname{gram}(\mathrm{g})$ \\
\hline \multicolumn{3}{|c|}{ Radioactivity } \\
\hline picocurie per liter $(\mathrm{pCi} / \mathrm{L})$ & 0.037 & becquerel per liter $(\mathrm{Bq} / \mathrm{L})$ \\
\hline \multicolumn{3}{|c|}{ Hydraulic conductivity } \\
\hline foot per day (ft/d) & 0.3048 & meter per day $(\mathrm{m} / \mathrm{d})$ \\
\hline
\end{tabular}

Temperature in degrees Fahrenheit $\left({ }^{\circ} \mathrm{F}\right)$ may be converted to degrees Celsius $\left({ }^{\circ} \mathrm{C}\right)$ as follows:

${ }^{\circ} \mathrm{C}=\left({ }^{\circ} \mathrm{F}-32\right) / 1.8$

\section{Datums}

Vertical coordinate information is referenced to the North American Vertical Datum of 1988 (NAVD 88) unless otherwise noted. Horizontal coordinate information is referenced to the North American Datum of 1983 (NAD 83), unless otherwise noted. Altitude, as used in this report, refers to distance above the vertical datum.

\section{Supplemental Information}

Concentrations of chemical constituents in water are given in milligrams per liter (mg/L), micrograms per liter $(\mu \mathrm{g} / \mathrm{L})$, or picograms per liter $(\mathrm{pg} / \mathrm{L})$. Chemical concentrations and water temperature are given in metric (SI) units.

A milligram per liter $(\mathrm{mg} / \mathrm{L})$ is a unit expressing the concentration of chemical constituents in solution as weight (milligrams) of solute per unit volume (liter) of water. A concentration of 1,000 micrograms per liter ( $\mu \mathrm{g} / \mathrm{L}$ ) is equivalent to 1 milligram per liter. A concentration of 1,000 nanograms per liter (ng/L) is equivalent to 1 microgram per liter. At dissolved solids concentrations of about 7,000 mg/L or less, nanogram per liter is used interchangeably in this report with the related term part per trillion (ppt). A concentration of 1 million picograms per liter (pg/L, also picograms per kilogram or $\mathrm{pg} / \mathrm{kg}$ ) is equivalent to 1 milligram per liter. 
One tritium unit (TU) is equivalent to a concentration of 3.2 picocuries per liter and is equal a concentration of one atom of tritium per $10^{18}$ hydrogen atoms (tritium/hydrogen ratio $=10^{-18}$ ). A picocurie is a unit of radioactivity; 1 picocurie is defined as $3.7 \times 10^{-2}$ decays per second; or in International System of Units (SI) terminology, $3.7 \times 10^{-2}$ becquerel.

Horizontal hydraulic conductivity is given in units of feet per day. Vertical hydraulic conductivity is given in units of feet per year.

\section{Abbreviations}

$\begin{array}{ll}< & \text { less than } \\ +/- & \text { plus or minus } \\ \text { CWU } & \text { chemical waste unit } \\ \text { CLU\#3 } & \text { Clinton landfill unit \#3 } \\ { }^{3} \mathrm{H} & \text { tritium or hydrogen-3 } \\ \mathrm{n}_{\mathrm{e}} & \text { effective porosity (dimensionless) } \\ \text { Kh } & \text { horizontal hydraulic conductivity } \\ \text { Kv } & \text { vertical hydraulic conductivity } \\ \text { NAVD 88 } & \text { North American Vertical Datum of 1988 } \\ \text { NWIS } & \text { National Water Information System } \\ \text { NWOL } & \text { National Water Quality Laboratory } \\ \text { PVC } & \text { polyvinyl chloride } \\ \text { PCBs } & \text { polychlorinated biphenyls } \\ \text { OA } & \text { quality assurance } \\ \text { TSCA } & \text { Toxic Substances Control Act } \\ \text { TU } & \text { tritium units } \\ \text { US } & \text { United States } \\ \text { USGS } & \text { U.S. Geological Survey } \\ \text { Vv } & \text { vertical groundwater velocity }\end{array}$





\title{
Application of Hydrogeology and Tritium-Based Ground water-Age Estimates to Assess the Travel Time of Groundwater at the Site of a Landfill to the Mahomet Aquifer near Clinton, Illinois
}

\author{
By Robert T. Kay and Paul M. Buszka
}

\section{Abstract}

The U.S. Geological Survey used interpretations of hydrogeologic conditions and tritium-based groundwater age estimates to assess the travel time of groundwater at a landfill site near Clinton, Illinois (the "Clinton site") where a chemical waste unit (CWU) was proposed to be within the Clinton landfill unit \#3 (CLU\#3). Glacial deposits beneath the CWU consist predominantly of low-permeability silt- and clay-rich till interspersed with thin (typically less than 2 feet in thickness) layers of more permeable deposits, including the Upper and Lower Radnor Till Sands and the Organic Soil unit. These glacial deposits are about 170 feet thick and overlie the Mahomet Sand Member of the Banner Formation. The Mahomet aquifer is composed of the Mahomet Sand Member and is used for water supply in much of east-central Illinois.

Eight tritium analyses of water from seven wells were used to evaluate the overall age of recharge to aquifers beneath the Clinton site. Groundwater samples were collected from six monitoring wells on or adjacent to the CLU\#3 that were open to glacial deposits above the Mahomet aquifer (the upper and lower parts of the Radnor Till Member and the Organic Soil unit) and one proximal production well (approximately 0.5 miles from the CLU\#3) that is screened in the Mahomet aquifer. The tritium-based age estimates were computed with a simplifying, piston-flow assumption: that groundwater moves in discrete packets to the sampled interval by advection, without hydrodynamic dispersion or mixing.

Tritium concentrations indicate a recharge age of at least 59 years (pre-1953 recharge) for water sampled from deposits below the upper part of the Radnor Till Member at the CLU\#3, with older water expected at progressively greater depth in the tills. The largest tritium concentration from a well sampled by this study (well G53S; $0.32 \pm 0.10$ tritium units) was in groundwater from a sand deposit in the upper part of the Radnor Till Member; the shallowest permeable unit sampled by this study. That result indicated that nearly all groundwater sampled from well G53S entered the aquifer as recharge before 1953. Tritium was detected in a trace concentration in one sample from a second monitoring well open to the upper part of the Radnor Till Member (well G07S; $0.11 \pm$ 0.09 tritium units), and not detected in samples collected from two monitoring wells open to a sand deposit in the lower part of the Radnor Till Member, from two samples collected from two monitoring wells open to the Organic Soil unit, and in two samples collected from a production well screened in the middle of the Mahomet aquifer (a groundwater sample and a sequential replicate sample). The lack of tritium in five of the six groundwater samples collected from the shallow permeable units beneath CLU\#3 site and the two samples from the one Mahomet aquifer well indicates an absence of post-1952 recharge. Groundwater-flow paths that could contribute post1952 recharge to the lower part of the Radnor Till Member, the Organic Soil unit, or the Mahomet aquifer at the CLU\#3 are not indicated by these data.

Hypothetical two-part mixtures of tritium-dead, pre-1953 recharge water and decay-corrected tritium concentrations in post-1952 recharge were computed and compared with tritium analyses in groundwater sampled from monitoring wells at the CLU\#3 site to evaluate whether tritium concentrations in groundwater could be represented by mixtures involving some post-1952 recharge. Results from the hypothetical two-part mixtures indicate that groundwater from monitoring well (G53S) was predominantly composed of pre-1953 recharge and that if present, younger, post-1955 recharge, contributed less than 2.5 percent to that sample. The hypothetical twopart mixing results also indicated that very small amounts of post-1952 recharge composing less than about 2.5 percent of the sample volume could not be distinguished in groundwater samples with tritium concentrations less than about $0.15 \mathrm{TU}$.

The piston-flow based age of recharge determined from the tritium concentration in the groundwater sample from monitoring well G53S yielded an estimated maximum vertical velocity from the land surface to the upper part of the Radnor Till Member of 0.85 feet per year or less. This velocity, if 
assumed to apply to the remaining glacial till deposits above the Mahomet aquifer, indicates that recharge flows through the 170 feet of glacial deposits between the base of the proposed chemical waste unit and the top of the Mahomet aquifer in a minimum of 200 years or longer. Analysis of hydraulic data from the site, constrained by a tritium-age based maximum groundwater velocity estimate, computed minimum estimates of effective porosity that range from about 0.021 to 0.024 for the predominantly till deposits above the Mahomet aquifer.

Estimated rates of transport of recharge from land surface to the Mahomet aquifer for the CLU\#3 site computed using the Darcy velocity equation with site-specific data were about 260 years or longer. The Darcy velocity-based estimates were computed using values that were based on tritium data, estimates of vertical velocity and effective porosity and available site-specific data. Solution of the Darcy velocity equation indicated that maximum vertical groundwater velocities through the deposits above the aquifer were 0.41 or 0.61 feet per year, depending on the site-specific values of vertical hydraulic conductivity (laboratory triaxial test values) and effective porosity used for the computation. The resulting calculated minimum travel times for groundwater to flow from the top of the Berry Clay Member (at the base of the proposed chemical waste unit) to the top of the Mahomet aquifer ranged from about 260 to 370 years, depending on the velocity value used in the calculation. In comparison, plausible travel times calculated using vertical hydraulic conductivity values from a previously published regional groundwater flow model were either slightly less than or longer than those calculated using site data and ranged from 230 to 580 years.

Tritium data from 1996 to 2011 USGS regional sampling of groundwater from domestic wells in the confined part of the Mahomet aquifer-which are 2.5 to about 40 miles from the Clinton site-were compared with site-specific data from a production well at the Clinton site. Tritium-based groundwater-age estimates indicated predominantly pre-1953 recharge dates for USGS and other prior regional samples of groundwater from domestic wells in the Mahomet aquifer. These results agreed with the tritium-based, pre-1953 recharge age estimated for a groundwater sample and a sequential replicate sample from a production well in the confined part of the Mahomet aquifer beneath the Clinton site.

The regional tritium-based groundwater age estimates also were compared with pesticide detections in samples from distal domestic wells in the USGS regional network that are about 2.5 to 40 miles from the Clinton site to identify whether very small amounts of post-1952 recharge have in places reached confined parts of the Mahomet aquifer at locations other than the Clinton site in an approximately 2,000 square mile area of the Mahomet aquifer. Very small amounts of post1952 recharge were defined in this analysis as less than about 2.5 percent of the total recharge contributing to a groundwater sample, based on results from the two-part mixing analysis of tritium data from the Clinton site. Pesticide-based groundwater-age estimates based on 22 detections of pesticides (13 of these detections were estimated concentrations), including atrazine, deethylatrazine (2-Chloro-4-isopropylamino-6-amino-s-triazine), cyanazine, diazinon, metolachlor, molinate, prometon, and trifluralin in groundwater samples from 10 domestic wells 2.5 to about 40 miles distant from the Clinton site indicate that very small amounts of post-1956 to post-1992 recharge can in places reach the confined part of the Mahomet aquifer in other parts of central Illinois. The relative lack of tritium in these samples indicate that the amounts of post-1956 to post-1992 recharge contributing to the 10 domestic wells were a very small part of the overall older groundwater sampled from those wells.

The flow process by which very small amounts of pesticide-bearing groundwater reached the screened intervals of the 10 domestic wells could not be distinguished between wellintegrity related infiltration and natural hydrogeologic features. Potential explanations include: (1) infiltration through man-made avenues in or along the well, (2) flow of very small amounts of post-1956 to post-1992 recharge through sparsely distributed natural permeable aspects of the glacial till and diluted by mixing with older groundwater, or (3) a combination of both processes.

Presuming the domestic wells sampled by the USGS in 1996-2011 in the regional study of the confined part of the Mahomet aquifer are adequately sealed and produce groundwater that is representative of aquifer conditions, the regional tritium and pesticide-based groundwater-age results indicate substantial heterogeneity in the glacial stratigraphy above the Mahomet aquifer. The pesticide-based groundwater-age estimates from the domestic wells distant from the Clinton site also indicate that parts of the Mahomet aquifer with the pesticide detections can be susceptible to contaminant sources at the land surface. The regional pesticide and tritium results from the domestic wells further indicate that a potential exists for possible contaminants from land surface to be transported through the glacial drift deposits that confine the Mahomet aquifer in other parts of central Illinois at faster rates than those computed for recharge at the Clinton site, including CLU\#3. This analysis indicates the potential value of submicrogram-per-liter level concentrations of land-use derived indicators of modern recharge to indicate the presence of very small amounts of modern, post-1952 age recharge in overall older, pre-1953 age groundwater.

\section{Introduction}

The U.S. Geological Survey (USGS) applied interpretations of hydrogeology and tritium-based groundwater age estimates to assess the travel time of groundwater at a landfill site near Clinton, Illinois (the "Clinton site"; fig. 1) where a chemical waste unit (CWU) was proposed to be within the Clinton landfill unit \#3 (CLU\#3; fig. 2). The Clinton site is approximately 2.1 miles (mi) south of the center of the city of Clinton, in De Witt County, Illinois (fig. 1). CLU\#3 has been permitted for the disposal of non-hazardous wastes. An 


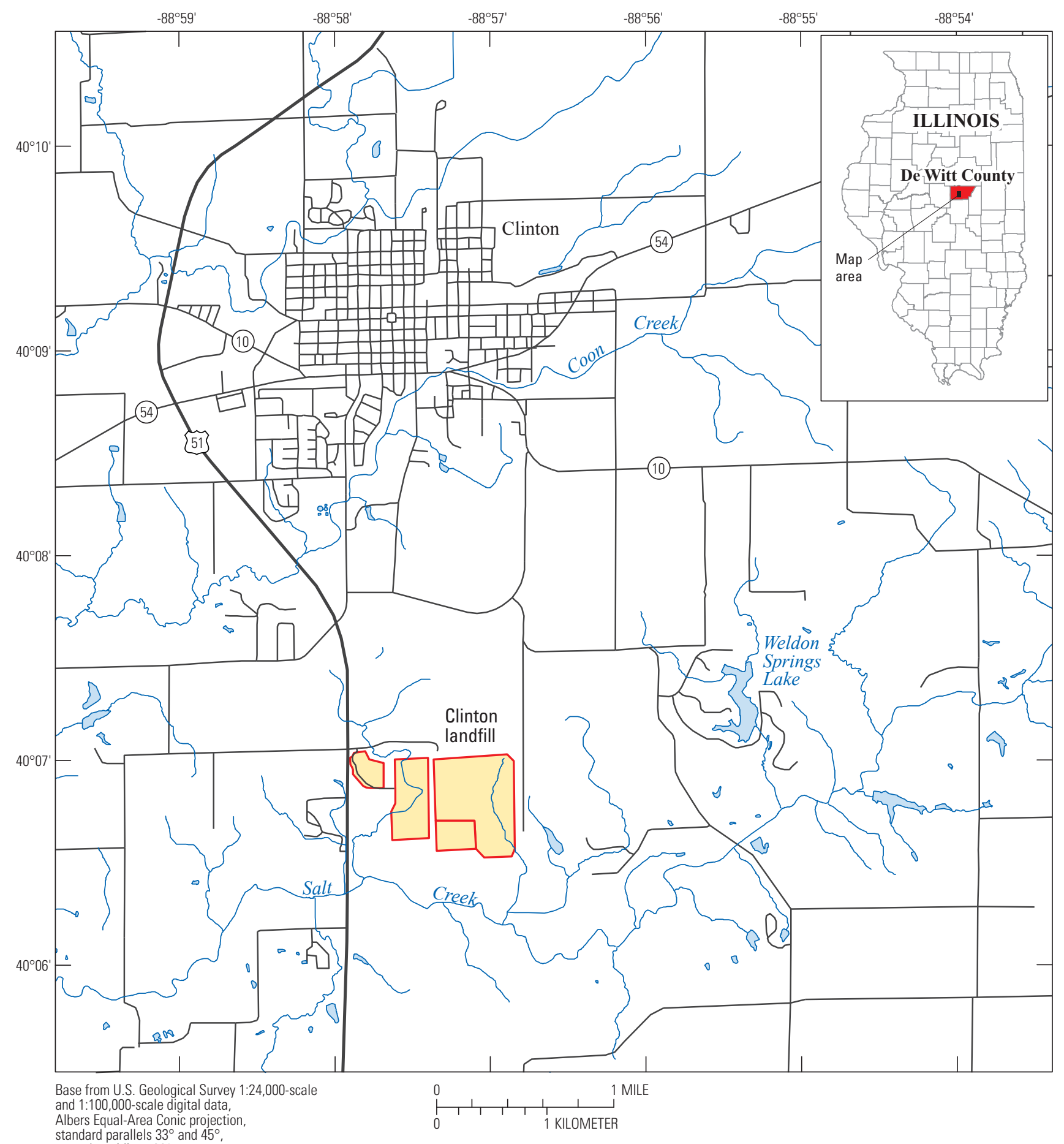

standard parallels $33^{\circ}$ and $45^{\circ}$,

Figure 1. Location of the Clinton site, near Clinton, Illinois.

application for a Toxic Substances Control Act (TSCA) permit to operate a chemical waste unit (CWU) within the Clinton landfill unit \#3 (CLU\#3) was previously submitted to the U.S. Environmental Protection Agency. The application, that has since been withdrawn, proposed to use the CWU part of CLU\#3 for the disposal of polychlorinated biphenyls (PCBs) and PCB-related items in accordance with the TSCA.
The proposed elevation of the base of the CWU is about 660 feet (ft) above the North American Vertical Datum of 1988 (NAVD 88). The USGS estimated the travel time of groundwater through the geologic deposits at the location of the proposed CWU, with emphasis on the travel time through the deposits that are between the base of the proposed CWU and the top of the underlying Mahomet aquifer. 


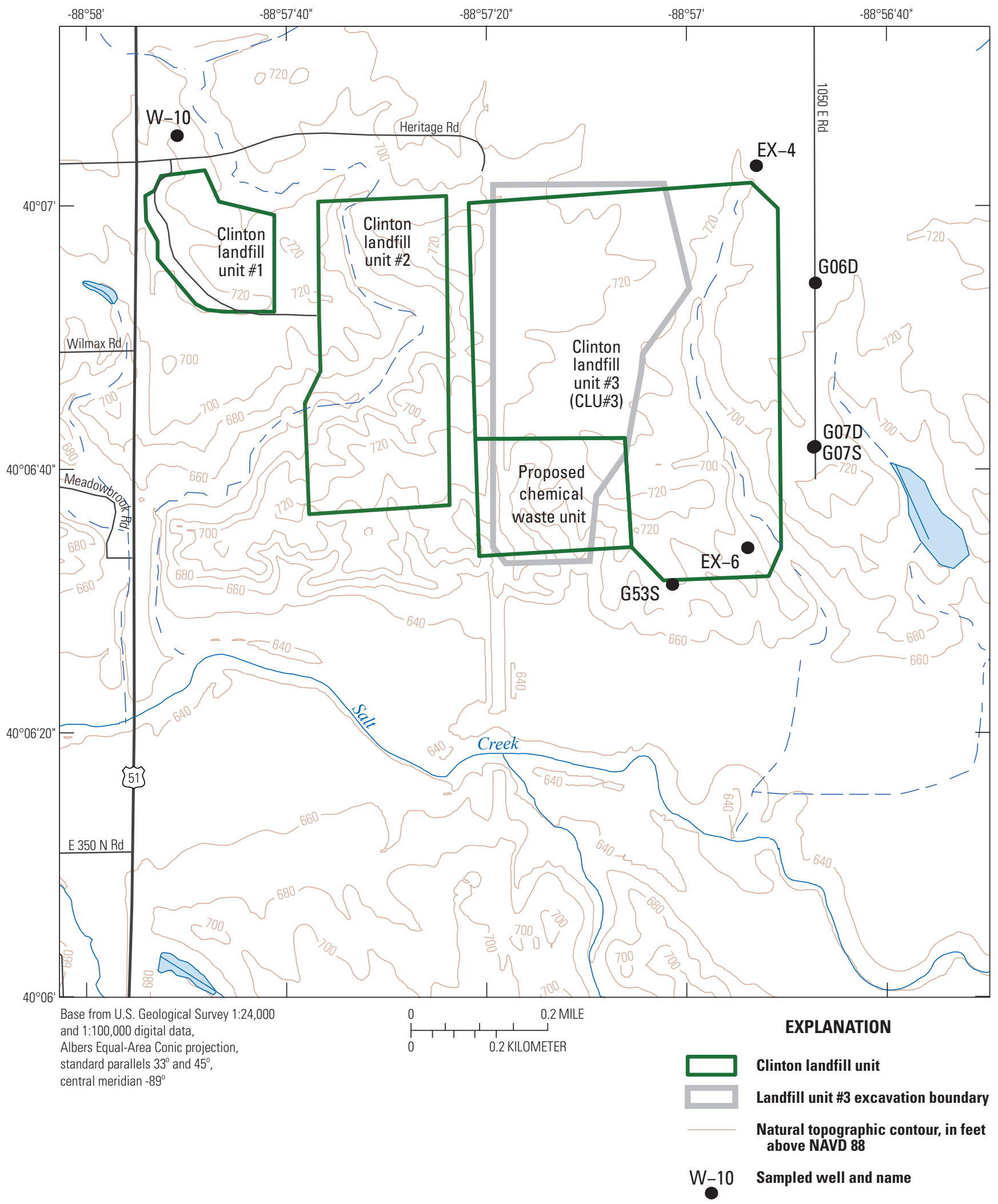

Figure 2. Location of solid waste units and sampled monitoring wells, Clinton site, near Clinton, Illinois. 


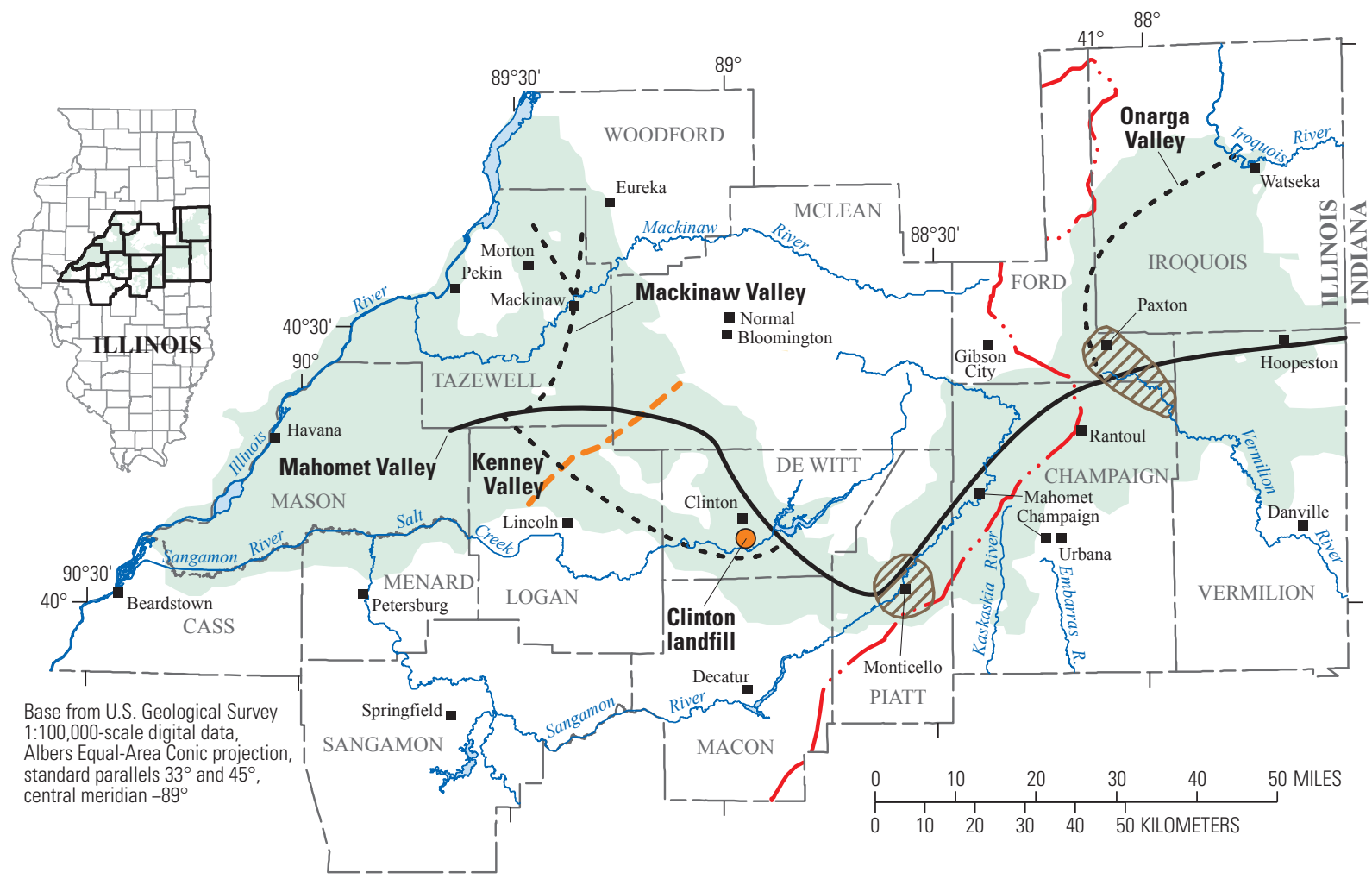

EXPLANATION

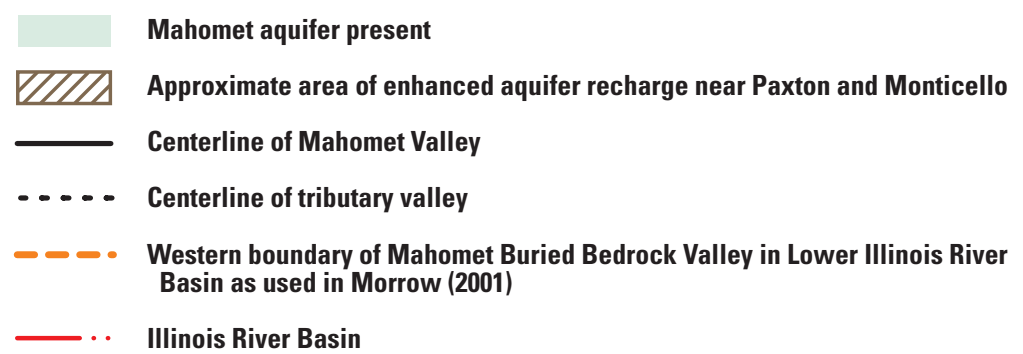

Figure 3. Location of the Mahomet aquifer and selected bedrock valleys in east-central Illinois (compiled and modified from Kempton and others, 1991; and Roadcap and others, 2011).

The Mahomet aquifer is about $170 \mathrm{ft}$ below the proposed CWU. The Mahomet aquifer is the water supply for numerous municipal, residential, commercial, irrigation, and industrial users in east-central Illinois (Roadcap and others, 2011; Kempton and others, 1991), including the City of Clinton. Approximately $170 \mathrm{ft}$ of till composed predominantly of silt and clay with intermittent sand layers is present beneath the proposed CWU. The till deposits confine the underlying Mahomet aquifer. The part of the Mahomet aquifer that includes the Clinton area has been described as a glacial drift aquifer in a deep buried valley (the Mahomet Buried Bedrock Valley in the Illinois River Basin, shown on fig. 3, p. 5 in Morrow, 2001) that is hydraulically confined beneath $100 \mathrm{ft}$ or more of clays and silts in the Wisconsinan, Illinoian, and pre-Illinoian drift (Morrow, 2001). This part of the Mahomet aquifer is referred to in the rest of this report as the "confined part of the Mahomet aquifer" and extends from the Illinois River Basin boundary in Champaign County westward to the western boundary of the Mahomet Buried Bedrock Valley in the Illinois River Basin in McLean and Logan Counties fig. 3).

\section{Purpose and Scope}

This report summarizes the results of a scientific investigation to assess the travel time of groundwater through the geologic deposits that are beneath CLU\#3, which includes the proposed CWU. This report describes site-specific data on the hydrogeology of the Mahomet aquifer and overlying glacial deposits covering an area of approximately 0.6 square miles at the Clinton site. Data collection, analysis, and interpretive 
Application of Hydrogeology and Tritium-Based Groundwater-Age Estimates to Assess the Travel Time of Groundwater

approaches used to understand groundwater travel times also are described. Tritium and water-level data collected during a sampling event on May 16, 2012, from six monitoring wells open to overlying deposits and one production well open to the Mahomet aquifer at and near CLU\#3 were used to estimate the age of the recharge contributing to groundwater in these deposits and to estimate the vertical rate of groundwater flow and travel time through the deposits. The age of recharge estimates were prepared using data from monitoring wells and a nearby production well approximately 0.5 miles from the CLU\#3. Additional analysis of groundwater velocity and travel time based on solution of the Darcy velocity equation, using site-specific data checked against regional information, also was prepared for this report. Assumptions used in the analyses, and the qualitative impact of these assumptions on the velocity estimates are discussed in this report.

Tritium-based estimates of recharge age at the Clinton site were computed assuming there was no mixing of groundwater with different ages between recharge and sampling. Hypothetical two-part mixtures of tritium-dead, pre-1953 recharge and decay-corrected tritium concentrations in post1952 recharge were computed and compared with tritium analyses in groundwater sampled from wells at the CLU\#3 site to evaluate whether tritium concentrations in groundwater could be represented by mixtures involving some post- 1952 recharge.

Estimates of groundwater age from the prior USGS and other regional sampling programs also were evaluated to understand whether post-1952 recharge has reached confined parts of the Mahomet aquifer outside of the vicinity of the CLU\#3 site and to understand the degree of heterogeneity in the overlying confining glacial deposits. This report provides interpretations of the presence or absence of post- 1952 recharge in the confined part of the Mahomet aquifer covering an area of approximately 2,000 square miles in east-central Illinois using the tritium and pesticide results from previously collected samples of groundwater. The tritium and pesticide results were from a prior 1996 to 2011 USGS sampling of preexisting domestic wells in the confined part of the Mahomet aquifer. The pre-existing domestic wells are 2.5 to about 40 miles from the CLU\#3 site and were selected to represent groundwater conditions in the Mahomet Buried Bedrock Valley in the Illinois River Basin for the USGS National Water Quality Assessment Program (fig. 3 in Morrow, 2001, p. 5). Pre-2002 tritium data reported by Hackley (2002) also were used for this evaluation.

\section{Regional Hydrogeologic Setting and Indications of Recharge to the Mahomet Aquifer from Prior Data}

The Mahomet aquifer occupies an east-west trending buried bedrock valley that extends in Illinois from an area on the east near Watseka, Hoopeston, and Danville westward to the
Illinois River near Havana (fig. 3). Numerous smaller tributary bedrock valleys also are present, including the Kenney Valley near the Clinton site and the Mackinaw Valley, which unite with the Mahomet Valley in Tazewell County (fig. 3). The various valley-fill deposits that compose most of the Mahomet aquifer consist primarily of sand and gravel deposits that are 30 to $100 \mathrm{ft}$ thick and directly overlay the bedrock. These sands and gravels are overlain primarily by silt-and-clay rich till deposits with interspersed sand and gravel deposits that typically are thin and of limited areal extent (Soller and others, 1999). The deposits of the Mahomet aquifer and the overlying (predominantly) till deposits are as much as $400 \mathrm{ft}$ thick (Hackley and others, 2010).

Groundwater flow in the Mahomet aquifer in the Clinton area is affected by a potentiometric high about 20 miles southeast of the Clinton site in the vicinity of the Sangamon River in Piatt County (Roadcap and others, 2011, recharge area shown in fig. 3). This potentiometric high, mapped by Hackley and others (2010, p. 1051), has been interpreted to be an area of "enhanced" recharge from land surface to the Mahomet aquifer, potentially because of the presence of hydraulically interconnected sand deposits above the Mahomet aquifer in central Piatt County (Panno and others, 1994; Mehnert and others, 2004; Hackley and others, 2010). The term "enhanced" was used by those authors to indicate that greater amounts of natural recharge reached the Mahomet aquifer in that area. Groundwater flow in the vicinity of this enhanced recharge area is east toward Urbana-Champaign and west through the Clinton area to the Illinois River. The Mahomet aquifer in western Piatt, De Witt, and McLean counties also appears to receive some recharge from the underlying bedrock through upward vertical groundwater flow (Panno and others, 1994; Hackley and others, 2010).

\section{Topographic Setting of the Clinton Site}

The natural surface topography in the vicinity of CLU\#3 typically is between 710 and $730 \mathrm{ft}$ NAVD 88 (fig. 2); however, much of the CLU\#3 area has been excavated to about $660 \mathrm{ft}$ NAVD 88 to accommodate waste disposal (fig. 2). As of 2013, topography decreases along a north-south trending natural drainage in the eastern one-third of CLU\#3, and at the western edge of CLU\#3. South of CLU\#3, the flood plain of Salt Creek has an elevation of about 640 to $650 \mathrm{ft}$ NAVD 88. The footprint of the proposed CWU also has been excavated, but the CWU excavation is north of the bluff in the southwestern part of CLU\#3, where surface topography ranges from about $680 \mathrm{ft}$ NAVD 88 next to the CWU to about $645 \mathrm{ft}$ in the flood plain. 


\section{Methods of Data Collection and Analysis for the Clinton Site}

The naming convention of some of the wells and borings was consistent with those used by and later revised by previous investigators at the Clinton site (PDC Technical Services, 2005; PDC Technical Services, 2006; Joyce Day, PDC Technical Services, Inc., written commun., 2012). Monitoring well EX-21S (fig. 4) was renamed well G53S (fig. 2, table 1). Monitoring well EX-24 (fig. 4) was renamed well G06D (fig. 2, table 1). Monitoring wells EX-23S and EX-23D (fig. 4) were renamed wells G07S and G07D (fig. 2, table 1). To maintain consistency with the terminology used by these investigators, the lithologic information presented in subsequent figures in this report uses the names of the original borings with which the lithologic descriptions are associated, whereas figure 2 uses the names of the monitoring wells from which the waterlevel and water-chemistry data were collected. Boring location names and well names are listed in table 1.

The hydrogeology of the CLU\#3 area, including the CWU, has been interpreted by USGS analysis of lithologic logs from about 45 borings (including clustered borings) drilled in the vicinity of the CLU\#3 (fig. 4), and from about 46 borings drilled in the vicinity of Clinton landfill unit \#2 (CLU\#2; fig. 2). The boring logs from CLU\#3 are presented in an appendix to the application for the CWU compiled by PDC Technical Services, Inc. (2005). The boring logs from the vicinity of CLU\#2 were provided by Joyce Day (PDC Technical Services, Inc., written commun., 2012). For consistency, this document uses the geologic terminology (Upper and Lower Radnor Till Sands, Organic Soil unit) and stratigraphic interpretations used by PDC Technical Services, Inc (2005). In addition, the results of hydraulic tests (slug tests, triaxial permeability tests, water-level measurements) done by PDC Technical Services (2005) are referenced in this report. However, the description of the presence, elevation, and extent of the geologic deposits, as well as other aspects of the hydrogeology in the CLU\#3 area (including groundwater velocity and effective porosity $\left[\mathrm{n}_{\mathrm{e}}\right]$ ) are based solely on analysis done by the USGS.

\section{Water Sample Collection at the Clinton Site}

Unfiltered water samples were collected for this investigation from monitoring wells EX-6, G53S, EX-4, G06D, G07S, and G07D; and from production well W-10 on May 16, 2012 (table 1 and fig. 2). Samples were collected from the monitoring wells by use of dedicated bladder pumps with intakes positioned within the screened interval of the well.

The monitoring wells were purged of three well volumes 8 days before the sampling event. The initial purging on May 8 was done to remove standing water from the monitoring wells to help ensure the presence of formation water in the wells when the samples were collected on May 16 (Andrew
Whelpley, PDC Technical Services, Inc., oral commun., 2012). The monitoring wells were subjected to additional purging and monitoring of field-measured water-quality properties $(\mathrm{pH}$, temperature, oxidation-reduction potential, dissolved oxygen, and specific conductance) as part of sample collection. During the sampling event, monitoring wells EX-6, EX-4, G07S, and G07D were purged and sampled using a standard low-flow technique (Puls and Barcelona, 1996).

Monitoring wells EX-6, G53S, EX-4, G06D, G07S, and G07D exhibited less than $0.30 \mathrm{ft}$ of drawdown during the May 16 purging and samples were collected after field-measured water-quality properties were stable for at least three consecutive readings collected at 5 minute intervals. Monitoring well G53S had more than $0.30 \mathrm{ft}$ of drawdown during purging and was pumped dry after approximately two well volumes were purged. The water level in monitoring well G53S was allowed to return to its hydrostatic condition before the sample was collected. Hydrostatic conditions were achieved within about 30 minutes of the well being pumped dry. Monitoring well G06D measured more than $0.30 \mathrm{ft}$ of drawdown during purging and was purged for three well volumes before sample collection. Production well $\mathrm{W}-10$ was purged for 30 minutes at a rate of 16.7 gallons per minute

(gal/min) by discharging water from a faucet approximately $120 \mathrm{ft}$ from the well. A sample and duplicate sample were then collected at the faucet. Water in the W-10 sample was not subjected to softening or other forms of treatment.

Groundwater samples for tritium analysis were collected in USGS laboratory-approved 1-liter (L) plastic bottles and shipped to the USGS Isotope Tracer Laboratory in Menlo Park, California within 2 days of collection. Samples were contained, stored, and shipped in accordance with USGS protocols (Koterba and others, 1995).

\section{Laboratory Analysis of Groundwater Samples From the Clinton Site}

Groundwater samples were analyzed for tritium at the laboratory in mid-September 2012, using an electrolytic enrichment and liquid scintillation analytical method similar to that described in USGS method R-1172-76 (Thatcher and others, 1977, p. 73). Tritium data from this method are reported as concentrations in tritium units (TU) with a 1-sigma combined standard uncertainty, consistent with the method described in McCurdy and others (2008, p. 8-9), with the exception that the data are not censored to a method reporting limit. One TU is equal to a concentration of one tritium atom per $10^{18}$ hydrogen atoms (tritium atom to hydrogen atom ratio equals $10^{-18}$ ) (Thatcher and others, 1977, p. 8). A liquid scintillation counter measures the number of disintegrations per minute when tritium in the sample decays by beta emission to stable helium. This count rate is related to the count rate of a sample of known concentration to determine the tritium concentration of the sample. The count rate has a Poisson distribution and the longer the count time, the better the accuracy. The counting 


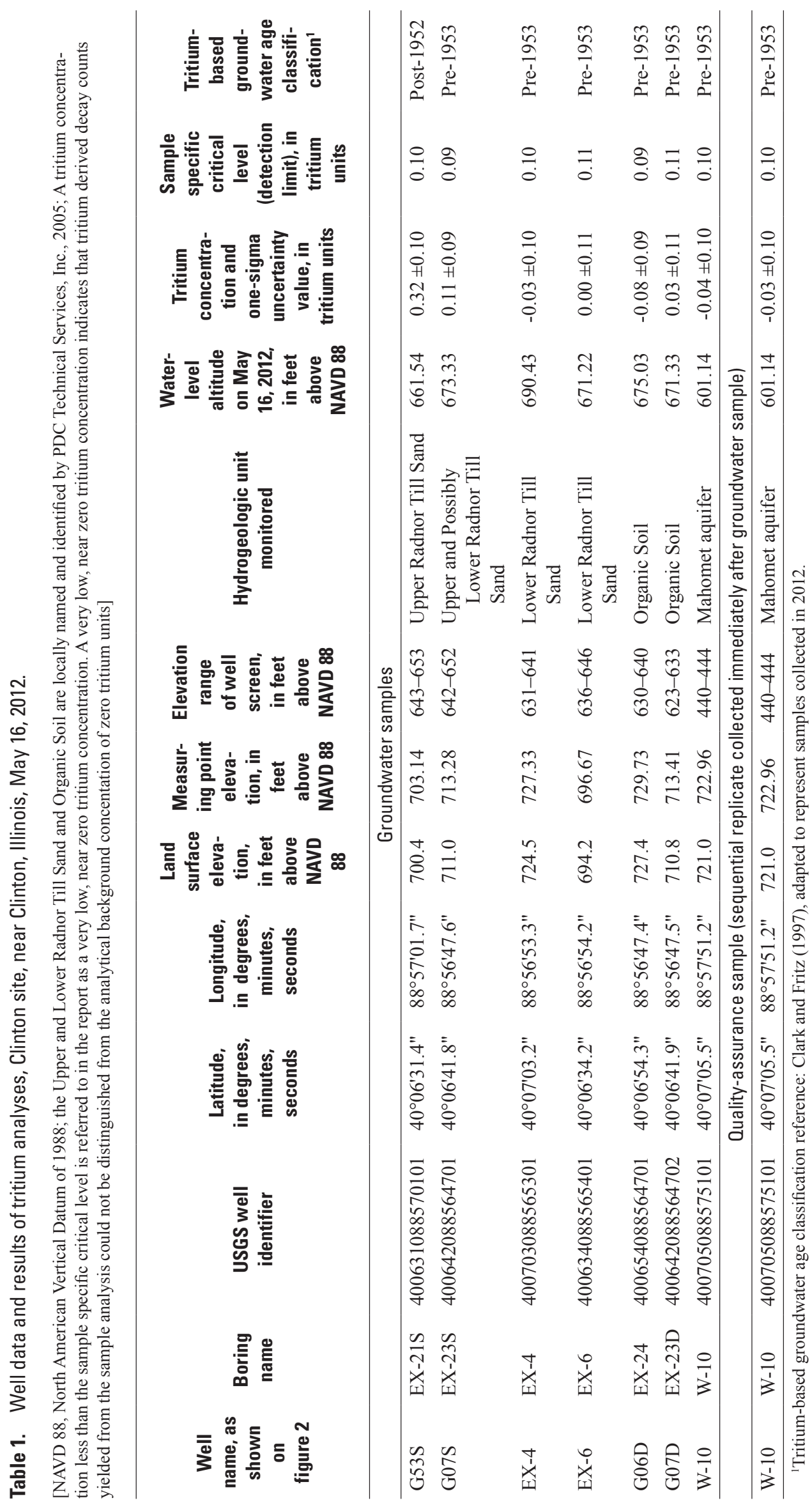




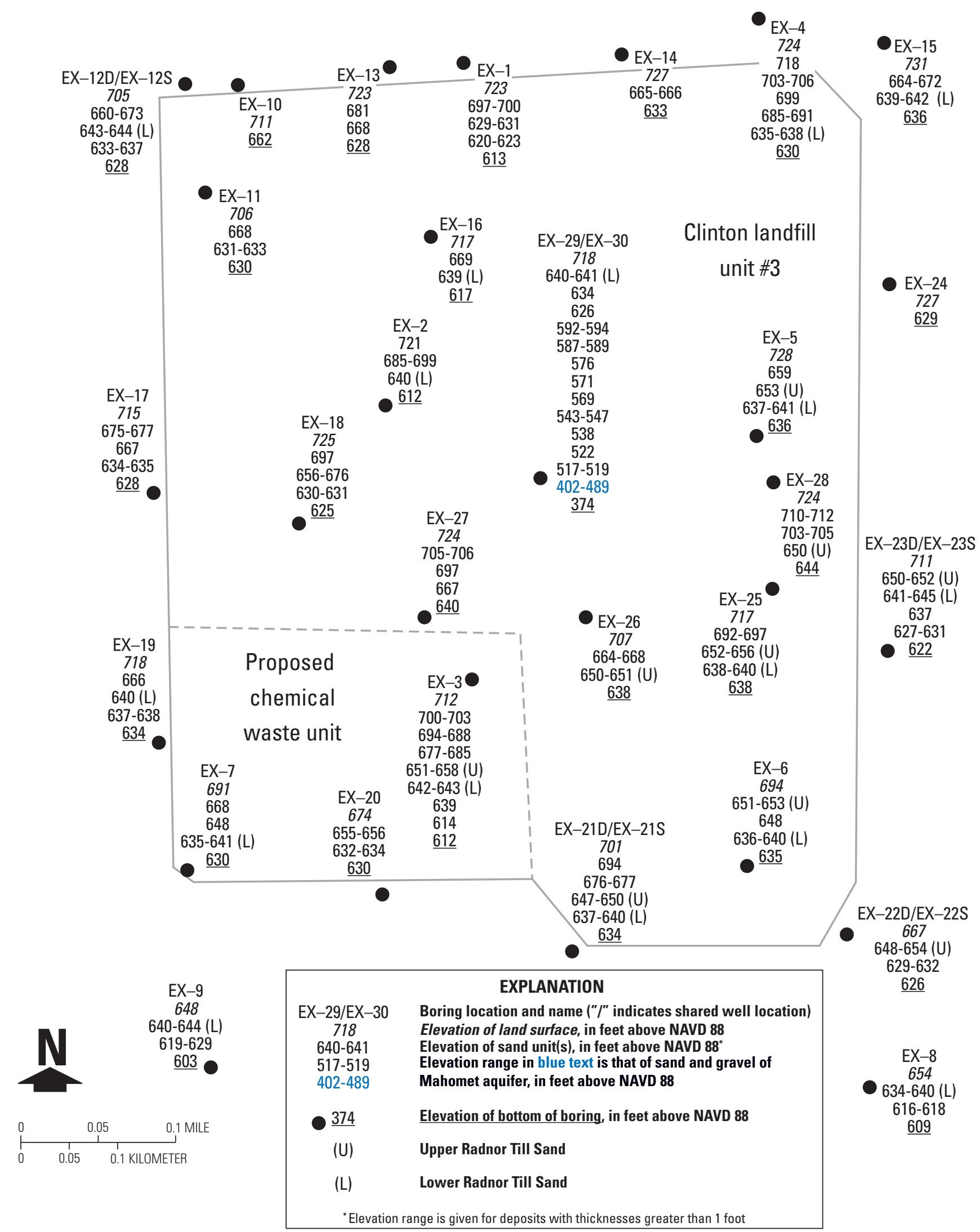

Figure 4. Well and boring locations and the elevations of sand deposits, within predominantly silt and clay deposits, and in the Mahomet aquifer in the vicinity of Clinton landfill unit \#3, near Clinton, Illinois. 
(analytical) uncertainty is indicated by the 1-sigma precision estimate in table 1, which may be read as "plus or minus" the counting error value. The true concentration of tritium in a sample has an approximately 68 percent probability (based on one standard deviation of the radioactivity count) of being within the 1-sigma uncertainty value of the measured value (McCurdy and others, 2008). For example, there is a 68 percent probability that the true concentration of tritium in a sample with a reported tritium concentration of $1.0 \mathrm{TU}$ and a 1-sigma uncertainty of $\pm 0.25 \mathrm{TU}$ is between 0.75 and $1.25 \mathrm{TU}$.

In cases when the tritium concentration, minus its 1-sigma uncertainty, is equal to or less than zero, that tritium concentration is reported in table 1 , but is considered to be not significantly different from zero. In cases when the tritium concentration, minus its 1-sigma uncertainty, is greater than zero, that tritium concentration is reported and is regarded as the true concentration (McCurdy and others, 2008).

\section{Interpretation of Recharge Using Tritium Data}

Tritium $\left({ }^{3} \mathrm{H}\right)$ is a radioactive form of the hydrogen atom that contains a proton and two neutrons. Tritium is produced naturally by the bombardment of atmospheric nitrogen by cosmic radiation (Grosse and others, 1951). Atmospheric tritium and oxygen then combine to form tritiated water, which enters the groundwater system as recharge from precipitation. The natural concentration of tritium in precipitation is estimated to be between 5 and 20 tritium units (TU; Kauffman and Libby, 1954; Payne, 1972). The value used in this report to describe initial, pre-1953 atmospheric testing concentration of tritium in precipitation was $8 \mathrm{TU}$, as described by Thatcher (1962). Tritium also was created as a by-product of atmospheric testing of thermonuclear bombs from 1951 through 1980, with particularly large amounts produced from 1951 through 1962 (Clark and Fritz, 1997). Tritium concentrations in precipitation have been measured monthly at a site in Ottawa, Canada, from 1953 to at least 2002 (International Atomic Energy Agency, 2006). Tritium concentrations generally increased from about $30 \mathrm{TU}$ in late 1953 to about $6,000 \mathrm{TU}$ in 1963 , returning to near natural levels (about $19 \mathrm{TU}$ at Ottawa, for example) by about 1993 (fig. 5A).

Radioactive decay of tritium leads to decreases in tritium concentration with time (fig. $5 B$ ). For example, recharge from precipitation with a tritium concentration of $8 \mathrm{TU}$ in 1951 (Thatcher, 1962) would have a tritium concentration of about $0.3 \mathrm{TU}$ in 2012 according to the equation:

$$
c(t)=c\left(t_{0}\right) * e^{-(0.693 t / 12.33)}
$$

Where:

$c(t) \quad$ is the tritium concentration at the time of sample collection and analysis (2012),

$t \quad$ is the time in years between the start time and the time being considered $(\mathrm{t}=61$ years from 1951 to 2012),
$c\left(t_{0}\right) \quad$ is the starting tritium concentration when tritium in precipitation entered the groundwater system as recharge (8 TU),
$t_{0} \quad$ is the time when tritium in precipitation entered the groundwater system as recharge (in this example 1951),
$e \quad$ is a constant equal to 2.71828 , and
12.33 is the half-life of tritium in years (Lucas and Unterweger, 2000).

Mixing and reaction of waters are complexities that are ignored in simple models of tritium concentrations in groundwater. A basic assumption made in an analysis of tritium-based indications of groundwater age is that the groundwater is undergoing uniform or "piston" flow. Piston flow is a simplified and idealized concept of groundwater flow in which groundwater moves in discrete packets by advection, without hydrodynamic dispersion or mixing (Shapiro and others, 2012). In piston flow, preferential flow along secondary flow paths does not substantially contribute to the hydrologic system. With these assumptions, the tritium concentration in the groundwater sample represents the original tritium concentration in recharge from infiltrating precipitation, modified only by radioactive decay.

Groundwater that contained less than about $0.8 \mathrm{TU}$ in 1997 (Clark and Fritz, 1997, p. 185) and about 0.3 TU or less in 2012 is assumed to be "submodern" and free of "bomb tritium" and to have entered groundwater as recharge before about 1953. Those values are based on a pre-1953, pre-atmospheric testing concentration of tritium in precipitation of $8 \mathrm{TU}$ and assume that tritium concentrations in water subsequently changed only because of radioactive decay. Groundwater that contained about $0.8 \mathrm{TU}$ or more tritium in 1997 and more than 0.3 TU in 2012 is assumed to contain some component of bomb tritium or "modern" recharge and indicates that most of the recharge contribution to the groundwater sample was after about 1952. For the purposes of this report, water that recharged groundwater before about 1953 also will be referred to as "submodern" or pre-1953 recharge and water that recharged during or after 1953 will be referred to as "modern" or post-1952 recharge.

A piston-flow model consistent with that described in concept by Shapiro and others (2012) was used to explain the Clinton sitefield data and represent the overall movement of groundwater and tritium in the subsurface. An alternate two-part mixture hypothesis was included in the data analysis to evaluate whether tritium results are affected by the mixing of older, pre-1953 and younger, post-1952 water during groundwater flow between recharge and sampling. Hypothetical two-part mixtures were computed by varying the assumed percentage of tritium-dead recharge from before 1953 and decay- modified recharge from a year between 1953 and 2002. Decay-modified values of tritium in precipitation used for these estimates were based on values computed from Ottawa, Canada precipitation between 1953 and 2002. 

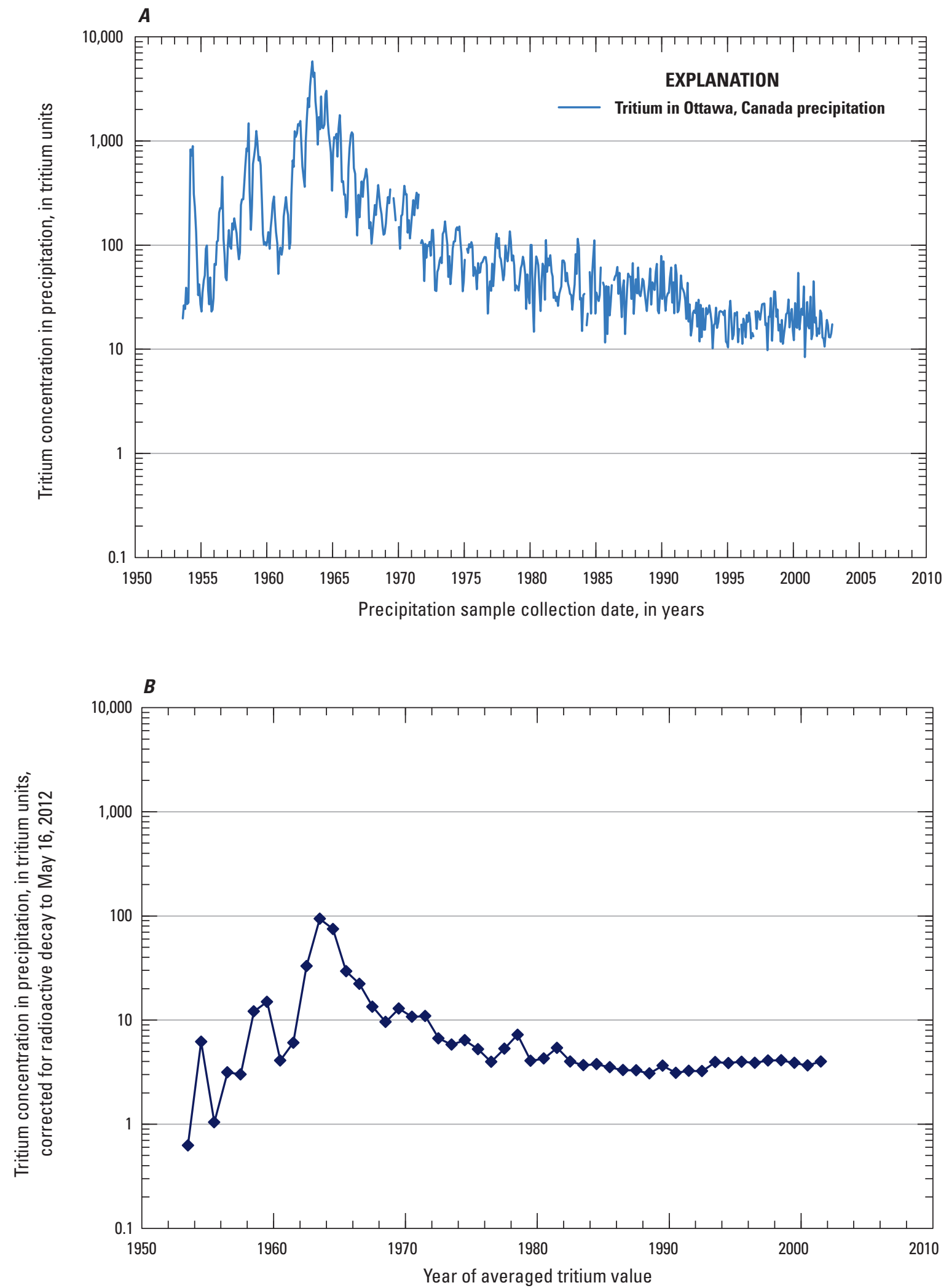

Figure 5. Concentrations of tritium in precipitation and decay-corrected, annual average concentrations of tritium in precipitation, decay corrected to the date of sampling (May 16, 2012). A, concentrations of tritium in precipitation from Ottawa, Canada, 1952 to 2002 and $B$, decay-corrected, annual average concentrations of tritium in precipitation. Data from $B$ were used to estimate tritium concentrations in 1953 to 2002 recharge to groundwater for two-part mixture computations. 


\section{Hydrogeology, Estimates of Groundwater Age, and Assessment of Groundwater Travel Time at the Clinton Site}

Recharge and vertical groundwater flow to the Mahomet aquifer in areas overlain predominantly by glacial till is affected by several factors, including

- the horizontal continuity and hydraulic character of the glacial till deposits,

- horizontal and vertical continuity of water-bearing units within the glacial till,

- the presence or absence of interstitial and secondary porosity and the character of vertical permeability through the units, and

- the direction of groundwater flow, as indicated by water-level gradients vertically between the glacial till units and the underlying Mahomet aquifer.

This section of the report discusses these elements of the groundwater flow system beneath the Clinton site, with particular attention to techniques that provide indications of recharge and rates of vertical groundwater flow beneath the CLU\#3 site and the proposed CWU.

\section{Hydrogeology and Estimates of Groundwater Age at the Clinton Site}

The Quaternary-aged deposits beneath CLU\#3 at the Clinton site consist of the Banner Formation deposits, which are divided into the Mahomet Sand Member and the overlying deposits of the Hillary Till Member and Tilton Till Member (fig. 6; Soller and others, 1999; Daniel Drommerhausen, Shaw Environmental, Inc., written commun., 2013). The Mahomet aquifer is composed of the Mahomet Sand Member and is used for water supply in much of east-central Illinois (Roadcap and others, 2011). The Banner Formation is overlain by the Glasford Formation, which consists of the Smithboro Till Member, the Vandalia Till Member, the Radnor Till Member, and the Berry Clay Member. The Glasford Formation is overlain by the Roxana Silt and Robein Silt Member of the Mason Group (referred to in this report as the Roxana Silt-Robein Silt Member), the Tiskilwa Formation of the Wedron Group, and the surficial Peoria Silt. At the Clinton site, the deposits above the Berry Clay Member have been excavated at CLU\#3 so that the base of the proposed CWU will be directly overlying the Berry Clay Member.

Assessment of hydrogeologic conditions throughout the glacial stratigraphy at the Clinton site was limited by the fact that almost all of the available site borings at CLU\#3 terminate more than $100 \mathrm{ft}$ above the top of the Mahomet aquifer (figs. 4, 7-11). Boring EX-30 is the only boring at CLU\#3 to penetrate the Mahomet aquifer. Boring CSM-1, about $750 \mathrm{ft}$ west of the western boundary of CLU\#3 (fig. 7), also penetrates the Mahomet aquifer. Boreholes EX-30 and CSM-1 were abandoned before this study so no monitoring wells are open to the Mahomet aquifer at the landfill.

\section{Continuity of Deposits at the Clinton Site}

The Quaternary-aged geologic deposits beneath CLU\#3 at the Clinton site consist predominantly of low- permeability silt-and-clay rich till with thin interspersed sands (typically less than $2 \mathrm{ft}$ ) and peat (figs. 5, 6, 8-11). When present, sand deposits, particularly laterally or vertically continuous sand deposits, have the potential to be pathways for lateral off-site flow and vertical flow of groundwater. For example, Hackley and others (2010) describe how stacked sand deposits near a river valley may have created a hydrologic window in the glacial deposits above the Mahomet aquifer at one distal location in Piatt County (over 20 miles from the Clinton site). Assessment of the location and potential interconnectedness of sand deposits therefore was a focal point of this investigation. For the purposes of this report a sand deposit was classified as substantially continuous if it was present at a similar elevation beneath a part, though not all of the CLU\#3 or the CWU. For example, a sand deposit classified as substantially continuous may be present within the eastern one-half of CLU\#3, but not in smaller areas beneath CLU\#3 where till or peat may be at the elevation of the sand deposit in one or more borings.

Assessment of the lateral and vertical continuity of the sand deposits was based on correlations interpreted from an examination of lithologic logs from borings and cross sections (figs. 5, 7-11). Vertically continuous sand deposits were not identified above the Mahomet aquifer beneath CLU\#3 at the Clinton site. Subsequent discussion is of the lateral continuity of the sand deposits unless vertical continuity is expressly described. Horizontally continuous till, sand or other deposits are considered to be present when at similar elevations or along a spatial trend in elevation, as described in lithologic logs from borings at CLU\#3 and the surrounding area. Because this discussion focuses on hydrogeologic characteristics of the Clinton site, the geologic deposits are discussed in order of increasing depth below land surface.

Although this discussion focuses on the continuous sand deposits, the silt-and-clay rich till deposits, within which the sands are vertically and horizontally interspersed, are both laterally and vertically continuous beneath CLU\#3. Roadcap and others (2011, p. 24) indicate that regionally, groundwater does not readily flow through the fine-grained Quaternary deposits (silt, clay, or till) above the Mahomet aquifer, in part, because the pore spaces are small and not well interconnected. Secondary permeable features, if present, have the potential to create paths of hydraulic interconnection of sand units across glacial till deposits. Subsurface evidence of secondary permeable features previously described as possible in till deposits 


\begin{tabular}{|c|c|c|c|c|c|c|}
\hline Period & Group & Formation & $\begin{array}{c}\text { Member or } \\
\text { unit }\end{array}$ & $\begin{array}{c}\text { Approximate } \\
\text { elevation, } \\
\text { in feet above North } \\
\text { American Vertical } \\
\text { Datum of } 1988\end{array}$ & Description & Pertinent features \\
\hline \multirow{10}{*}{ 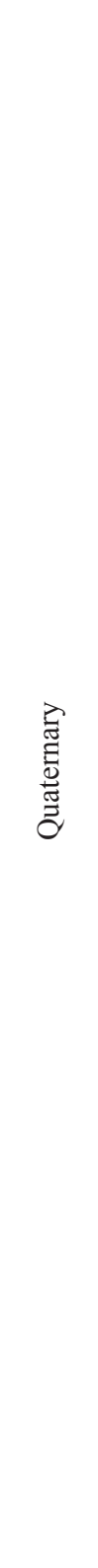 } & Mason & $\begin{array}{c}\text { No formation } \\
\text { defined }\end{array}$ & Peoria Silt unit & $\begin{array}{c}\text { Typically less } 2 \text { feet } \\
\text { thick }\end{array}$ & $\begin{array}{l}\text { Modern soil, } \\
\text { silty loess }\end{array}$ & $\begin{array}{l}\text { Deposits excavated to } \\
\text { accommodate landfill. } \\
\text { Vertical fractures likely in } \\
\text { at least part of these }\end{array}$ \\
\hline & Wedron & Tiskilwa & $\begin{array}{l}\text { No member } \\
\text { defined }\end{array}$ & $\begin{array}{c}\text { Typically about } 720 \\
\text { to } 671\end{array}$ & $\begin{array}{l}\text { Till with } \\
\text { interspersed } \\
\text { sands }\end{array}$ & $\begin{array}{c}\text { conductivity } \\
0.024 \text { feet per year from site } \\
\text { triaxial permeability tests. }\end{array}$ \\
\hline & Mason & $\begin{array}{c}\text { No formation } \\
\text { defined }\end{array}$ & $\begin{array}{l}\text { Roxana Silt- } \\
\text { Robein Silt } \\
\text { Member }\end{array}$ & $663-670$ & $\begin{array}{c}\text { Peat and organic } \\
\text { silt }\end{array}$ & $\begin{array}{l}\text { conductivity of Wedron } \\
\text { Group } 0.37 \text { feet per year } \\
\text { from regional model. }{ }^{2}\end{array}$ \\
\hline & \multirow{7}{*}{ 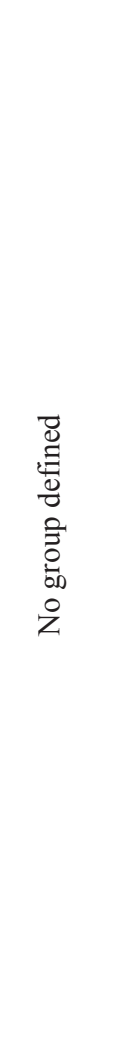 } & \multirow{4}{*}{ Glasford } & Berry Clay & $658-666$ & Blue clay & \multirow{4}{*}{$\begin{array}{l}\text { Berry Clay directly beneath } \\
\text { landfill excavation. Upper } \\
\text { Radnor Till Sand at } 647- \\
650 \text { feet at well G53S. } \\
\text { Vertical hydraulic } \\
\text { conductivity } 0.035 \text { feet per } \\
\text { year from site triaxial } \\
\text { permeability tests }{ }^{1} \text { and } \\
0.037 \text { feet per year from } \\
\text { regional model }{ }^{2} \text {. Vertical } \\
\text { fracturing not described in } \\
\text { borings at Clinton landfill } \\
\text { unit } \# 3 .^{1}\end{array}$} \\
\hline & & & Radnor Till & $631-657$ & $\begin{array}{c}\text { Till with } \\
\text { interspersed } \\
\text { sands }\end{array}$ & \\
\hline & & & Vandalia Till & $539-630$ & $\begin{array}{l}\text { Till with } \\
\text { interspersed } \\
\text { sands }\end{array}$ & \\
\hline & & & Smithboro Till & $522-538$ & $\begin{array}{l}\text { Till with } \\
\text { interspersed } \\
\text { sands }\end{array}$ & \\
\hline & & \multirow{3}{*}{ Banner } & Tilton Till & $503-521$ & $\begin{array}{l}\text { Till with } \\
\text { interspersed } \\
\text { sands }\end{array}$ & \multirow{2}{*}{$\begin{array}{c}\text { Vertical hydraulic } \\
\text { conductivity } 0.015 \text { feet per } \\
\text { year from regional model. } \\
\text { No site triaxial permeability } \\
\text { tests from this deposit. }{ }^{1}\end{array}$} \\
\hline & & & Hillary Till & $490-502$ & Till & \\
\hline & & & Mahomet Sand & $402-489$ & Sand and gravel & $\begin{array}{l}\text { Mahomet aquifer is } \\
\text { composed of the Mahomet } \\
\text { Sand Member. No } \\
\text { permeability tests at Clinton } \\
\text { site from this formation. }{ }^{1}\end{array}$ \\
\hline
\end{tabular}

${ }^{1}$ Site permeability test information from PDC Technical Services, Inc. (2005).

${ }^{2}$ Regional model data from Roadcap and others (2011).

Figure 6. Glacial stratigraphy of Quaternary-aged deposits and pertinent features beneath Clinton landfill unit \#3, near Clinton, Illinois.

in other areas of the confined part of the Mahomet aquifer by Roadcap and others (2011, p. 27-28) were not identified in logs of borings drilled at the Clinton site that were reviewed for this study. These secondary permeable features described as possible in other areas of the Mahomet aquifer included vertically interconnected sands deposited during downcutting of streams during interglacial periods or by upward injection of overpressured sands from buoyancy failures of till during 


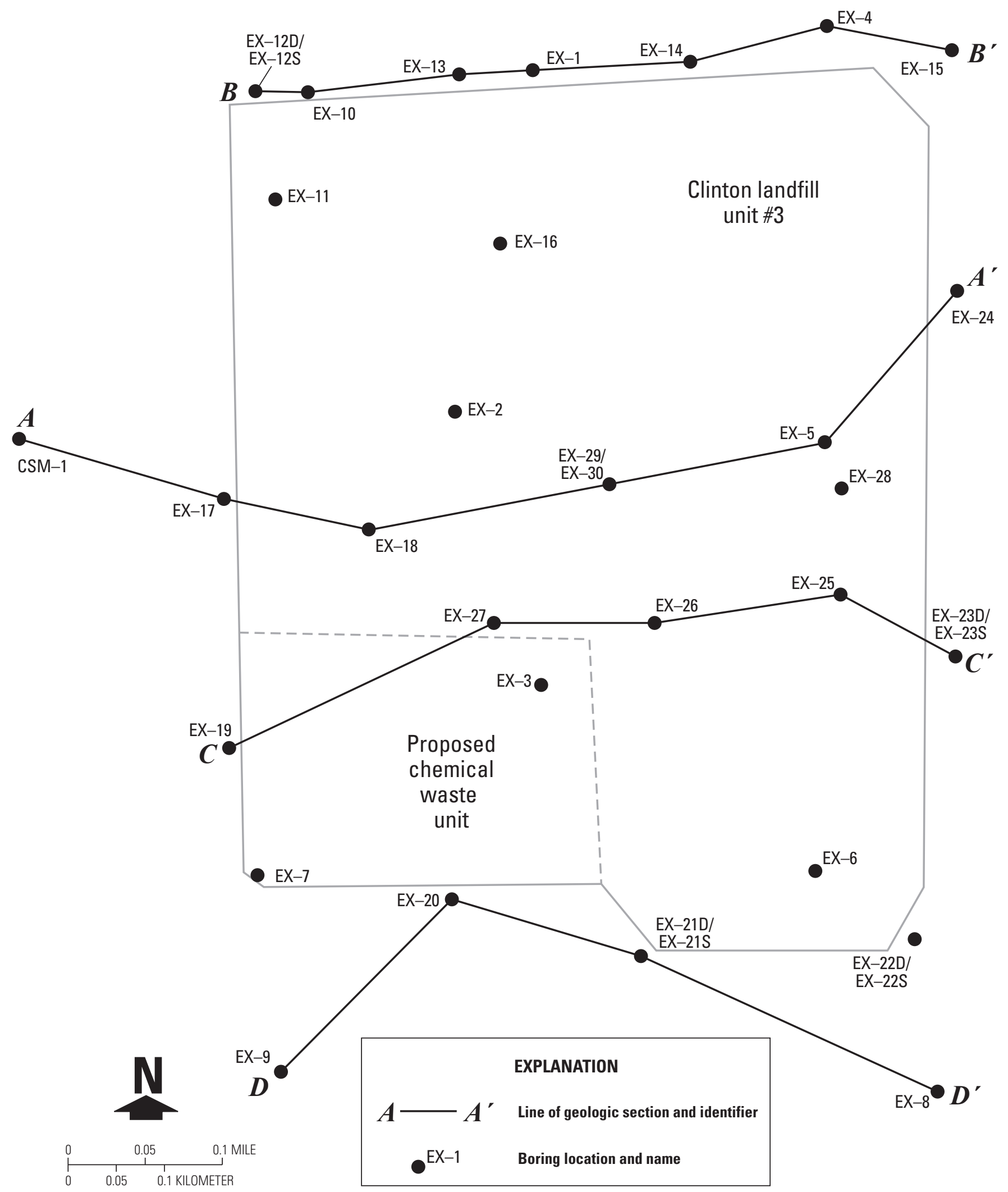

Figure 7. Location of lines of geologic section, Clinton landfill unit \#3, near Clinton, Illinois. 

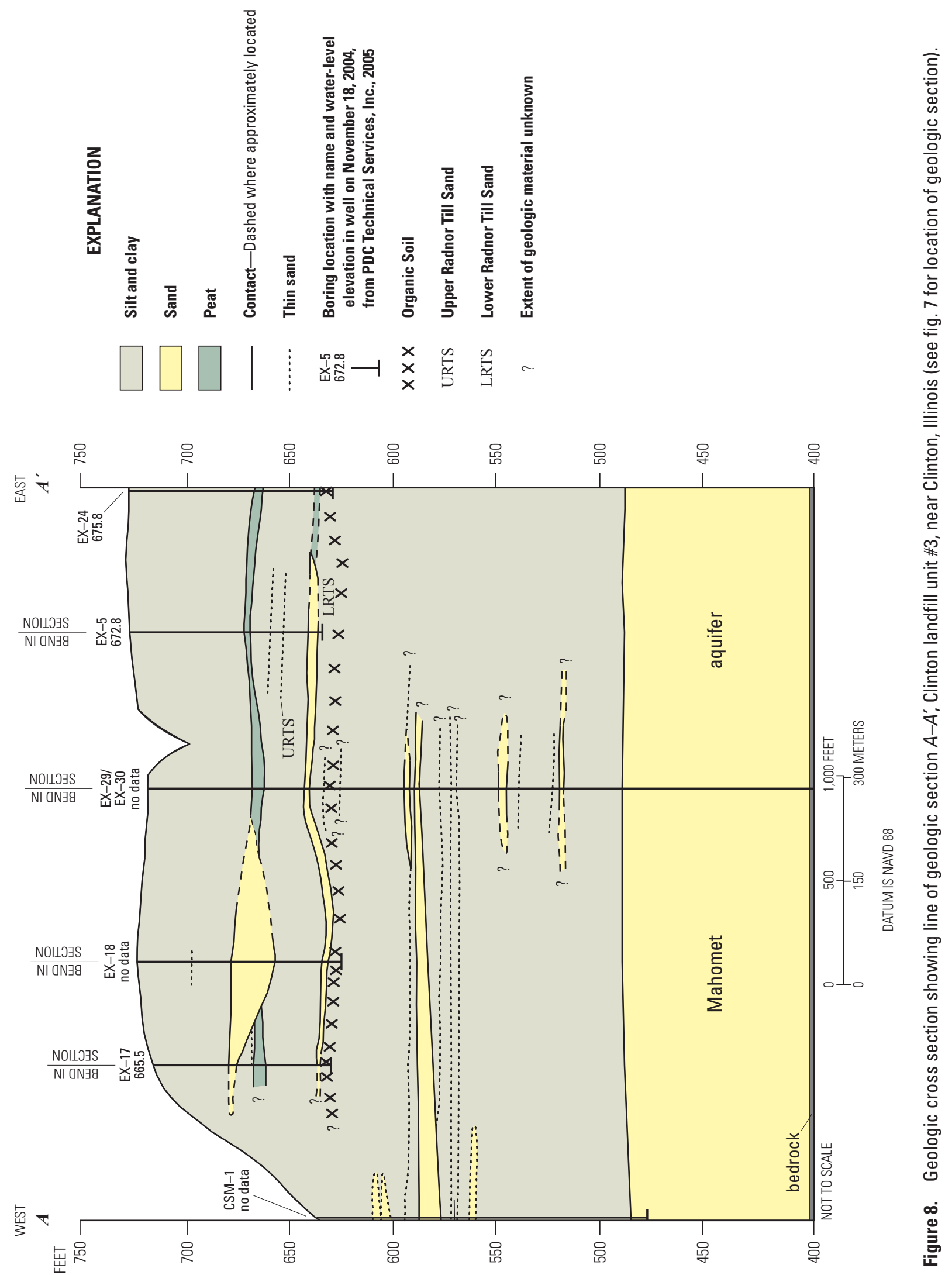


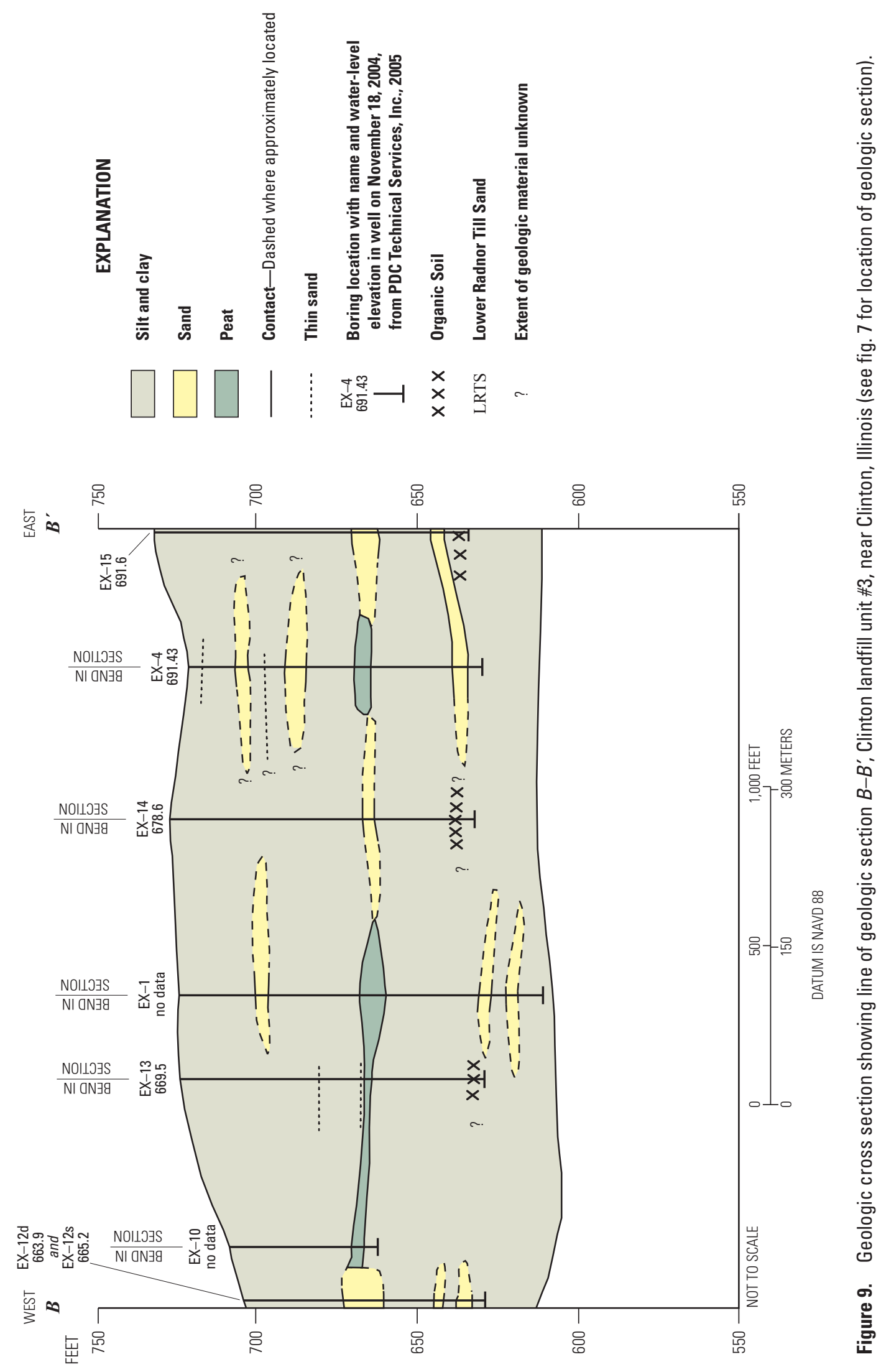




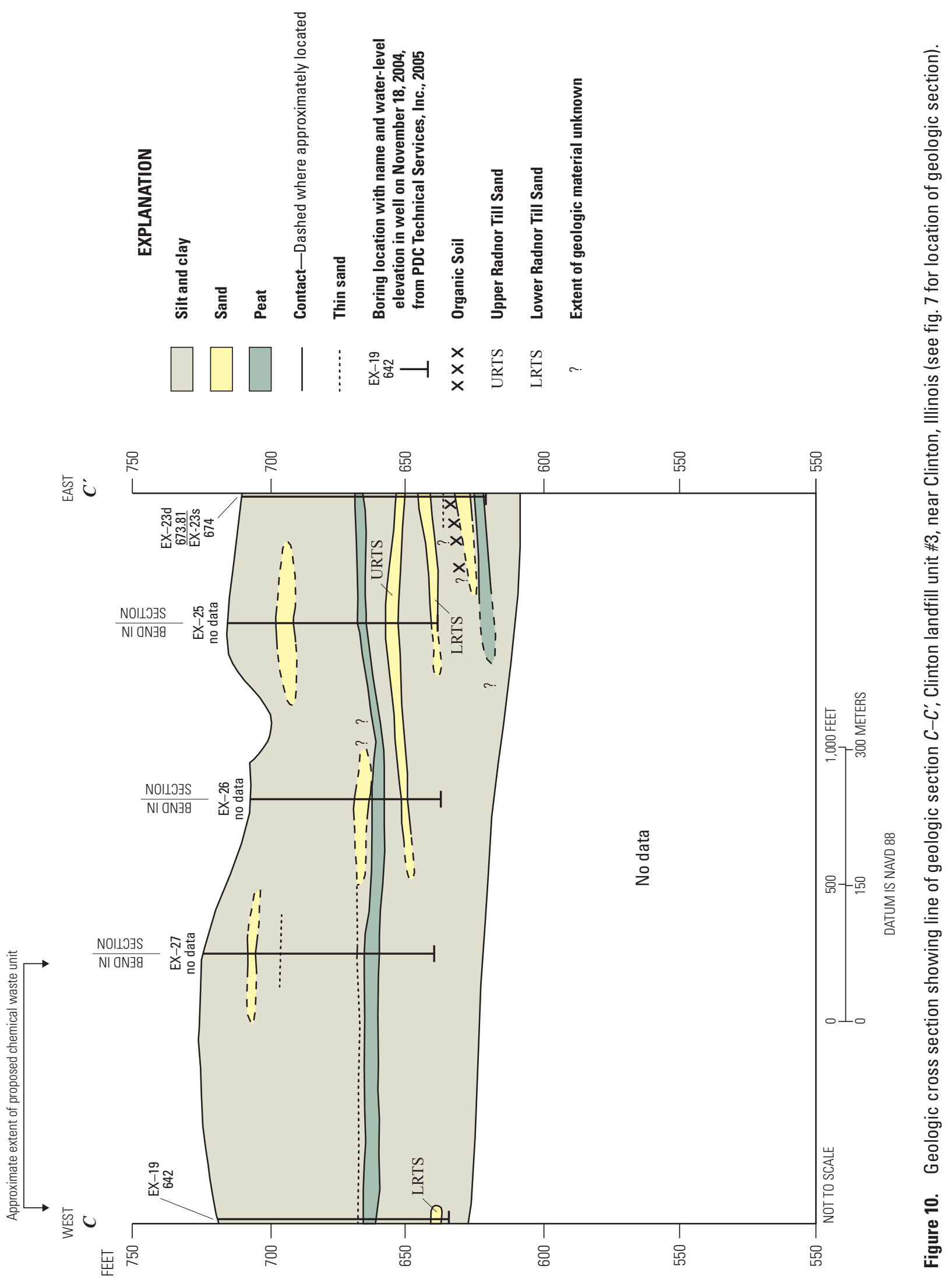



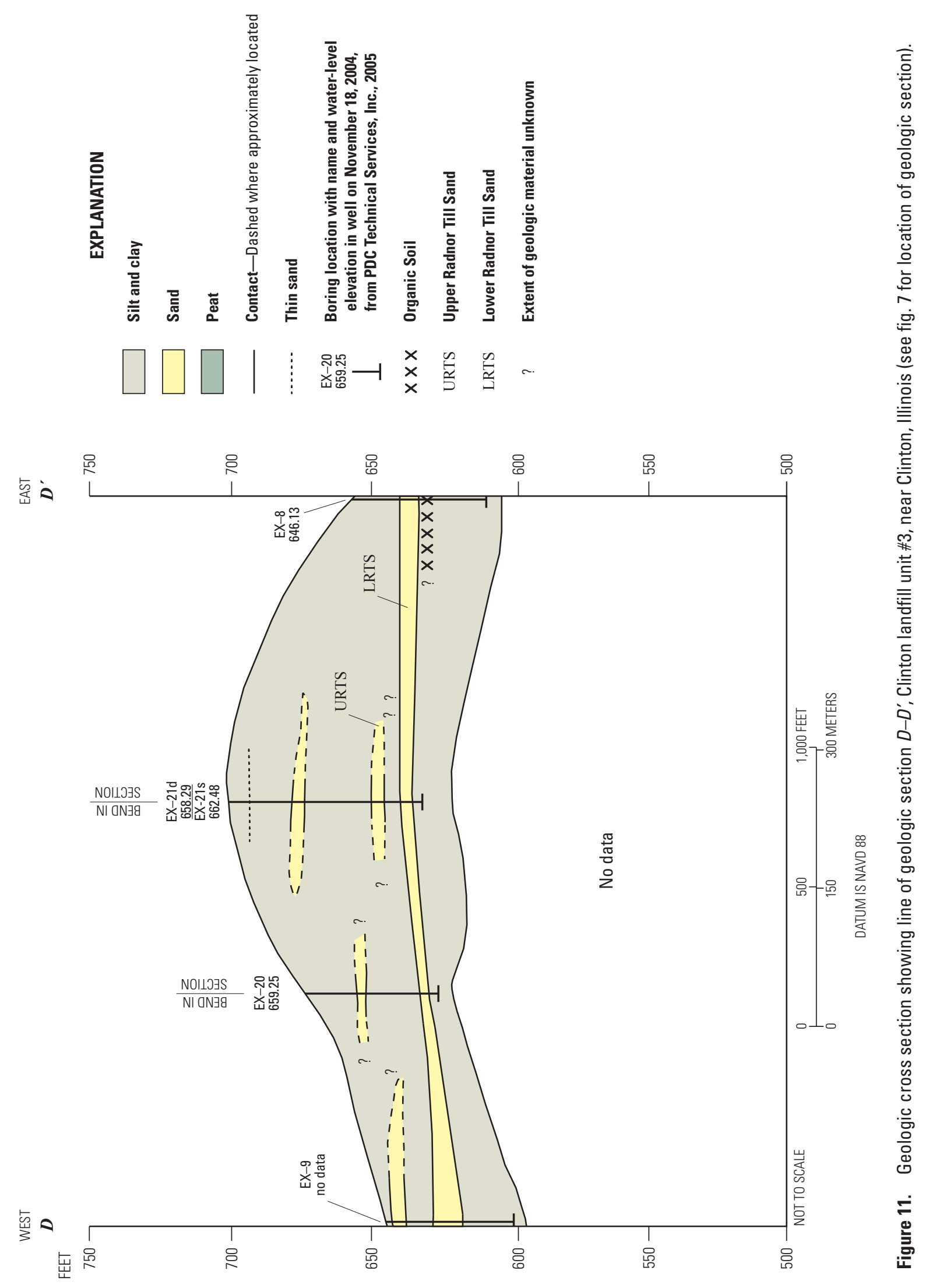
glacial ice readvances and smaller scale vertical conduits from fracturing of till deposits during the loading and unloading of the glacial ice (Roadcap and others 2011, p. 27-28). The relative abundance or lack of vertical permeable interconnections of the permeable units through the till deposits are indirectly evaluated later in this report through tritium-based groundwater age estimates prepared using analyses of groundwater sampled from these permeable units at the Clinton site.

\section{Shallow Sand Deposits}

The shallowest substantially continuous sand deposit at CLU\#3 is present at variable elevations, potentially being present at multiple elevations at the same boring, but typically is above about $675 \mathrm{ft}$ NAVD 88 (figs. 5, 7-11). Most or all of this deposit has been removed by excavation done within the footprint of CLU\#3, but sand remains in areas that have not been excavated. Before excavation, this deposit typically was about $2-15 \mathrm{ft}$ thick. The deposit was present at borings EX-1, EX-3, EX-4, EX-21, EX-25, EX-27, and EX-28 and may be present at EX-17 and EX-18. This sand deposit was identified at elevations between 675 and $705 \mathrm{ft}$ in several borings surrounding CLU\#2, indicating that the deposit is spatially extensive where it has not been excavated. CLU\#2 has been excavated to an elevation of about $625 \mathrm{ft}$ NAVD 88 (Joyce Day, PDC Technical Services, Inc., written commun. 2012), so this sand deposit is absent within the waste footprint of CLU\#2. No wells monitor this deposit at CLU\#3 but lithologic logs compiled during drilling describe saturated sands at an elevation of about $700 \mathrm{ft}$ at borings EX-1, EX-3, EX-4, EX-25, and EX-28 and "wet to saturated" sands at about 705 $\mathrm{ft}$ at boring EX-27.

A second, substantially continuous sand deposit appears to be present at an elevation of about 666-668 ft NAVD 88 along the western edge of CLU\#3 at borings EX-7, EX-11, EX-12, EX-17, and EX-19 (fig. 4). Sand was observed at about this elevation beneath much of the northern and central parts of CLU\#3 at borings EX-13, EX-14, EX-15, EX-16, EX-18, EX-26, and EX-27 (fig. 4). This deposit also has been removed by excavation in much of the CLU\#3 footprint, including the CWU, but it may remain beneath the excavation in parts of the CLU\#3 footprint and in areas outside the excavation. Before excavation, this deposit typically was less than $0.5 \mathrm{ft}$ thick beneath CLU\#3, but was as much as $20 \mathrm{ft}$ thick at boring EX-18. Several borings in the vicinity of CLU\#2 intersected sand deposits as thick as $20 \mathrm{ft}$ that included the 666-668 ft interval, indicating that the sand thickens to the west. This deposit also has been excavated within the waste footprint of CLU\#2 and was at least partly saturated near CLU\#2. Because shallow groundwater typically flows toward the nearest surface-water body, flow in these shallow sands in the vicinity of the CWU was expected to be south toward Salt Creek.

\section{Shallow Peat Deposit}

A substantially continuous peat deposit is present beneath much of the CLU\#3 area at an elevation of about $660-670 \mathrm{ft}$ NAVD 88 , as indicated on geologic sections $A-A^{\prime}, B-B$ ' and $C-C^{\prime}$ (figs. 8-10). This peat deposit was absent beneath parts of the proposed CWU along geologic section $D-D$ ' (fig. 11) and was not identified in borings EX-6 and EX-7 (fig. 7; boring logs in PDC Technical Services, Inc., 2005). The deposit also is absent in the east-central part of CLU\#3 at EX-5 and EX-28, although organic material was described at an elevation of about $673 \mathrm{ft}$ NAVD 88 in both of these borings. The peat deposit also is absent in local areas where the sand deposit (described in the previous paragraph) is present at this elevation (EX-12, EX-14, EX-15, EX-18). Where present, the peat deposit ranges in thickness from about 2 to $8 \mathrm{ft}$. This deposit also has been removed by excavation beneath much of CLU\#3, but remains in unexcavated areas.

\section{Upper Radnor Till Sand}

The next deepest substantially continuous sand deposit is in the upper part of the Radnor Till Member in the southeastern part of CLU\#3 at an elevation of about $651 \mathrm{ft} \mathrm{NAVD}$ 88 (fig. 4, 8-11). This deposit has been named the Upper Radnor Till Sand by PDC Technical Services, Inc. (2005) and is the uppermost deposit monitored by wells at CLU\#3. The Upper Radnor Till Sand ranges in thickness from about 0.25 to $3 \mathrm{ft}$, with the thickness generally increasing from north to south. The Upper Radnor Till Sand as identified at borings EX-3, EX-5, EX-6, EX-21, EX-22, EX-23, EX-25, EX-26, and EX-28, which are in the south-southeastern part of CLU\#3, including part of the CWU. Based on elevation, the Upper Radnor Till Sand also may be present at boring EX-20. Single-well aquifer tests (commonly called slug tests) done by PDC Technical Services, Inc., in monitoring wells G53S/ EX-21S, EX-22S, and G07S/EX-23S, which are open to the Upper Radnor Till Sand, yielded horizontal hydraulic conductivity $(\mathrm{Kh})$ values of $0.46,0.31$, and 0.027 feet per day $(\mathrm{ft} / \mathrm{d})$, respectively (units converted from PDC Technical Services, Inc., 2005).

Water levels measured in three monitoring wells open to the Upper Radnor Till Sand during 2003 and 2004 ranged from about 661 to $677 \mathrm{ft}$ and indicate a southwesterly flow direction (PDC Technical Services, Inc., 2005). The water levels measured in 2003-04 were consistent with the water levels measured by the USGS at the time of sampling (table 1) and indicate that the monitoring wells sampled from the Upper Radnor Till Sand for this investigation were hydraulically upgradient of CLU\#2 and were not affected by groundwater flow from CLU\#2.

The tritium concentration in the sample from monitoring well G53S $(0.32 \pm 0.10 \mathrm{TU}$; table 1$)$ was similar to the tritium concentration in $2012(0.3 \mathrm{TU})$ that represents recharge 
at the beginning of atmospheric testing in 1953 (as described in the section of this report titled "Interpretation of Recharge Using Tritium Data"). This tritium concentration indicates that groundwater in the sample from this monitoring well was submodern and entered the subsurface as recharge before the advent of bomb-influenced tritium in precipitation, about 1953 or before (Clark and Fritz, 1997); therefore, groundwater in the Upper Radnor Till Sand at this well infiltrated into the ground 59 years or more before sample collection. The Upper Radnor Till Sand at monitoring well G53S is at a depth of $50 \mathrm{ft}$ below land surface; the elevation of the land surface at well G53S is $700 \mathrm{ft}$ above NAVD 88 (table 1), and the top of the Upper Radnor Till Sand is $650 \mathrm{ft}$ above NAVD 88 at well G53S/boring EX21-S (fig. 4). If the assumption of piston groundwater flow is valid, the vertical rate of water movement from land surface to the Upper Radnor Till Sand, including flow through the (likely thin) unsaturated zone, is calculated to be $50 \mathrm{ft}$ in a minimum of 59 years, or no more than $0.85 \mathrm{ft} / \mathrm{yr}$.

The trace concentration of detectable tritium in the sample collected from the second on-site well screened in the Upper Radnor Till Sand, monitoring well G07S $(0.11 \pm 0.09$ TU, table 1), indicates the water in this sample was submodern and recharged groundwater before 1953. Groundwater in this monitoring well had an age greater than 59 years at the time of sampling. Monitoring well G07S is open to the Upper Radnor Till Sand at an elevation of about 650-652 ft NAVD 88 and a second lower sand deposit at an elevation of 641 to $645 \mathrm{ft}$ NAVD 88 (table 1 and fig. 5). The sample was a mixture of water from the Upper Radnor Till Sand and the Lower Radnor Till Sand. The small tritium concentrations from the two wells that produce water from the Upper Radnor Till Sand (G53S and $\mathrm{G} 07 \mathrm{~S}$; table 1) relative to the estimated tritium concentrations in recharge (fig. $5 B$ ) indicate very slow rates of vertical recharge to the Upper Radnor Till Sand. These data also indicate that vertical pathways of groundwater flow from land surface to these wells in the Upper Radnor Till Sand at the Clinton site, if present, are sparse in their distribution.

\section{Lower Radnor Till Sand}

Below the Upper Radnor Till Sand, the next deepest substantially continuous sand deposit is in the lower part of the Radnor Till Member. This deposit has been named the Lower Radnor Till Sand by PDC Technical Services, Inc. (2005) and is present beneath most of CLU\#3 and the western part of CLU\#2 at an elevation of about $640 \mathrm{ft}$ NAVD 88 (fig. 4, $8-11$ ). This deposit ranges in thickness from about 0.25 to $5 \mathrm{ft}$ and tends to be thinnest in the center and northwestern parts of the CLU\#3. The Lower Radnor Till Sand was identified at borings EX-2, EX-3, EX-4, EX-5, EX-6, EX-7, EX-8, EX-9, EX-12, EX-15, EX-16, EX-19, EX-21, EX-23, EX-25, and EX-29. Slug tests done by PDC Technical Services, Inc., in six monitoring wells open to the Lower Radnor Till Sand yield a geometric mean horizontal hydraulic conductivity of $1.5 \mathrm{ft} / \mathrm{d}$ (units converted from PDC Technical Services, Inc., 2005).
Water levels in nine monitoring wells open to the Lower Radnor Till Sand during 2003 and 2004 ranged from about 641 to $691 \mathrm{ft}$ and indicated a predominantly west-southwest groundwater flow direction in the Lower Radnor Till Sand (PDC Technical Services, Inc., 2005). These values were consistent with the water levels measured by the USGS during the May 16, 2012, sampling event (table 1) and indicate that the monitoring wells sampled from the Lower Radnor Till Sand for this investigation were hydraulically upgradient of CLU\#2. At monitoring well cluster EX-21S (open to the Upper Radnor Till Sand) and EX-21D (open to the Lower Radnor Till Sand) water levels indicate a downward vertical hydraulic gradient and the potential for downward flow from the Upper Radnor Till Sand to the Lower Radnor Till Sand (PDC Technical Services, Inc., 2005). The high water level in the Lower Radnor Till Sand at monitoring well EX-4 (table 1) is in an area where the Upper Radnor Till Sand is absent and cannot be used to assess vertical flow directions between these two deposits.

Tritium was not detected in the samples from the Lower Radnor Till Sand at monitoring wells EX-4 and EX-6 (table 1). This lack of detectable tritium in the samples indicates that the water in these wells entered the subsurface as recharge before 1953 (Clark and Fritz, 1997), making the age of the water in these wells more than 59 years at the time of sampling.

\section{Organic Soil Unit}

The deepest monitoring wells at CLU\#3 are open to the Organic Soil unit identified by PDC Technical Services, Inc. (2005). The Organic Soil unit appears to be a paleo-soil consisting of a mixture of silt and clay with organic material. The Organic Soil unit is present beneath most of CLU\#3 but is absent or not penetrated at several borings (figs. 8-11). This deposit typically is $1-2 \mathrm{ft}$ thick and at an elevation of about 631-635 ft NAVD 88 beneath CLU\#3. Slug tests done by PDC Technical Services, Inc. in eight monitoring wells open to the Organic Soil unit yielded a geometric mean Kh of $0.15 \mathrm{ft} / \mathrm{d}$ (units converted from PDC Technical Services, Inc., 2005).

Water levels measured in eight monitoring wells open to the Organic Soil unit during 2003 and 2004 ranged from elevations of about 659 to $680 \mathrm{ft}$ NAVD 88 and indicate a predominantly west-southwest flow direction (PDC Technical Services, Inc., 2005). These values and directions were consistent with the water levels measured by the USGS at the time of sampling (table 1) and indicate that the Organic Soil unit monitoring wells sampled for the current investigation were hydraulically upgradient of CLU\#2. At well cluster EX$12 \mathrm{~S}$ (open to the Lower Radnor Till Sand) and EX-12D (open to the Organic Soil unit) and at well cluster G07S (open to the Upper Radnor Till Sand) and G07D (open to the Organic Soil unit) water levels indicated downward vertical hydraulic gradients and the potential for downward flow at these monitoring wells (PDC Technical Services, Inc., 2005) (table 1). At well cluster EX-22S (open to the Upper Radnor Till Sand) and EX-22D (open to the Organic Soil unit) water 
levels indicated upward vertical hydraulic gradients and the potential for upward flow at these monitoring wells (PDC Technical Services, Inc., 2005).

Tritium was not detected in groundwater sampled from the Organic Soil unit at monitoring wells G06D and G07D (table 1). This lack of detection indicates the water in these monitoring wells entered the ground as recharge before 1953 (Clark and Fritz, 1997), making the age of the water in these wells more than 59 years at the time of sampling.

\section{Glasford Formation Below the Organic Soil Unit and the Banner Formation Tills}

No wells monitor the Glasford Formation deposits below the Organic Soil unit or the till members of the Banner Formation at CLU\#3 and tritium samples from those deposits could not be collected. Geologic interpretation of the deposits below the Organic Soil unit is based on lithologic logs for borings EX-29/EX-30 and CSM-1 (PDC Technical Services, Inc., 2005). These logs indicate the presence of numerous sand deposits at between elevations of about 562 and $626 \mathrm{ft}$ NAVD 88 at borings CSM-1 and EX-30 (fig. 4, 8). These deposits typically are less than $2 \mathrm{ft}$ thick, but can be as much as about $10 \mathrm{ft}$ thick. At least two of these sand deposits appear to be substantially continuous between borings CSM-1 and EX-30. An additional four sand deposits were identified at boring EX-30 between elevations of about 515 and $545 \mathrm{ft}$ NAVD 88; however, the additional four sand deposits were not detected at boring CSM-1.

\section{Mahomet Aquifer at the Clinton Site}

The Mahomet aquifer at the Clinton site is composed of the Mahomet Sand Member of the Banner Formation (fig. 6). The top of the Mahomet aquifer is at an elevation of about $489 \mathrm{ft}$ NAVD 88 and the bottom is at an elevation of about $402 \mathrm{ft}$ NAVD 88 at boring EX-30 in the vicinity of the Clinton site fig. 4, 6, 8). The Mahomet aquifer was identified in boring EX-30 at a depth of about $230-317 \mathrm{ft}$ below land surface. The area of the proposed CWU has been excavated to an elevation of about $660 \mathrm{ft}$ NAVD 88 and there is approximately $170 \mathrm{ft}$ of geologic material between the base of the CWU and the top of the Mahomet aquifer. Of this $170 \mathrm{ft}$ of material, about $155 \mathrm{ft}$ is silt, clay, or peat, with the remaining $15 \mathrm{ft}$ composed of 12 separate sand deposits, as in boring EX-30. The thickest of the 12 separate sand deposits in boring EX-30 is about $7 \mathrm{ft}$ at an elevation range from 651-658 ft NAVD 88 at EX-30.

The water-level elevation in the Mahomet aquifer at production well W-10 was measured to be about $601 \mathrm{ft}$ NAVD 88 during the May 16, 2012, sampling event (table 1). This elevation is consistent with regional assessments of the potentiometric surface for the Mahomet aquifer in the Clinton, Ill. area (Roadcap and others, 2011), and was at least $60 \mathrm{ft}$ lower than the water levels in the wells open to the Organic
Soil unit, Lower Radnor Till Sand, or Upper Radnor Till Sand deposits (table 1). Although well W-10 is approximately 0.5 mile from the CLU\#3 site (fig. 2), the large downward vertical hydraulic gradient between wells in the Organic Soil unit, Lower Radnor Till Sand and Upper Radnor Till Sand and $\mathrm{W}-10$ in the Mahomet aquifer indicates the existence of a considerable degree of hydraulic separation between these deposits and the Mahomet aquifer but also the potential for downward flow from these deposits to the aquifer. The vertical head difference between (1) the Organic Soil unit, Lower Radnor Till Sand and Upper Radnor Till Sand and (2) the Mahomet aquifer at the Clinton site additionally indicates an overall resistance to vertical flow from these deposits to the Mahomet aquifer; this resistance could be explained by the low vertical permeability of the predominantly fine grained glacial till deposits between these units and the Mahomet aquifer. These data indicate that the hydraulic interconnection between the Upper Radnor Till Sand, the Lower Radnor Till Sand and the Organic Soil unit through glacial till deposits to the Mahomet aquifer is limited.

Tritium was not detected in concentrations at or greater than reporting levels in the two samples collected from the Mahomet aquifer at well W-10 (table 1). Production well W-10 is open to the middle of the aquifer at 440-444 ft NAVD 88, about $45 \mathrm{ft}$ below the top of the aquifer. These data indicate that the groundwater at the open interval of well W-10, and likely in the Mahomet aquifer beneath CLU\#3 and the CWU, was likely recharged before 1953 (Clark and Fritz, 1997) and has an age of more than 59 years.

\section{Two-Part Mixing Model Evaluation of Tritium- Based Groundwater Age Estimates at the Clinton Site}

The validity of the piston-flow assumptions used to estimate groundwater age since recharge was evaluated by comparing the only notable tritium detection in groundwater from the 8 wells sampled at the Clinton site $(0.32 \pm 0.10 \mathrm{TU}$; monitoring well G53S), with hypothetical tritium concentrations computed from simulated two-part mixtures of pre-1953, tritium-dead recharge and post-1952 recharge containing tritium. The hypothetical concentrations were computed as if they had originated as a two-part mixture of submodern pre1953, tritium-dead recharge combined with 1 percent or more of modern recharge containing tritium concentrations from precipitation (fig. $5 \mathrm{~A}$ ) corrected for radioactive decay (fig. $5 \mathrm{~B}$ ) to the date the samples were collected (May 16, 2012).

Groundwater-age dates also were compared with estimates computed using a two-part model of recharge sources and ages of hypothesized two-part flow paths to the screened interval in the well and the hydraulic conductivity and porosity characteristics of an aquifer (International Atomic Energy Agency, 2006). The two-part or "binary" mixing model assumes that a water sample from a well represents a mixture 


\section{Application of Hydrogeology and Tritium-Based Groundwater-Age Estimates to Assess the Travel Time of Groundwater}

of groundwater from two distinct flow paths and age dates that intercept the well screen (Plummer and others, 1993). In comparison, the piston-flow model assumes that groundwaterflow paths contributing flow to the well essentially have the same recharge source, flow path, and age. The two-part mixing model is an idealized conceptual model used to represent the tritium concentration of a sample as a mixture of groundwater from pre-1953 and post-1952 recharge.

The following processes were used to evaluate sitespecific data with hypothetical two-part mixtures. If the tritium concentration in a sample from a CLU\#3 site well, such as that from monitoring well G53S (table 1), is similar to the hypothetical tritium concentration estimated from one or more two- part mixtures, those similarities can indicate the potential for recharge from multiple flow paths and ages at the well in amounts similar to those predicted in the two-part mixtures. Binary mixture results also were compared with samples containing very low, "near-zero" tritium concentrations to identify the smallest contribution of post-1952 groundwater that could be resolved.

Estimated tritium concentrations of hypothetical mixtures $\left(\mathrm{T}_{\text {mixture }}\right)$ were computed by varying percentages of submodern, pre-1953 (tritium dead) recharge and modern, post-1952 recharge simulated using decay corrected annual mean tritium concentrations at Ottawa, Canada from the years 1953 to 2002 , according to the following equation.

$$
\left.T_{\text {mixture }}=\left(f_{\text {old }} / 100\right) \times T_{\text {old }}+f_{\text {young }} / 100\right) \times T_{\text {young }}
$$

Where:

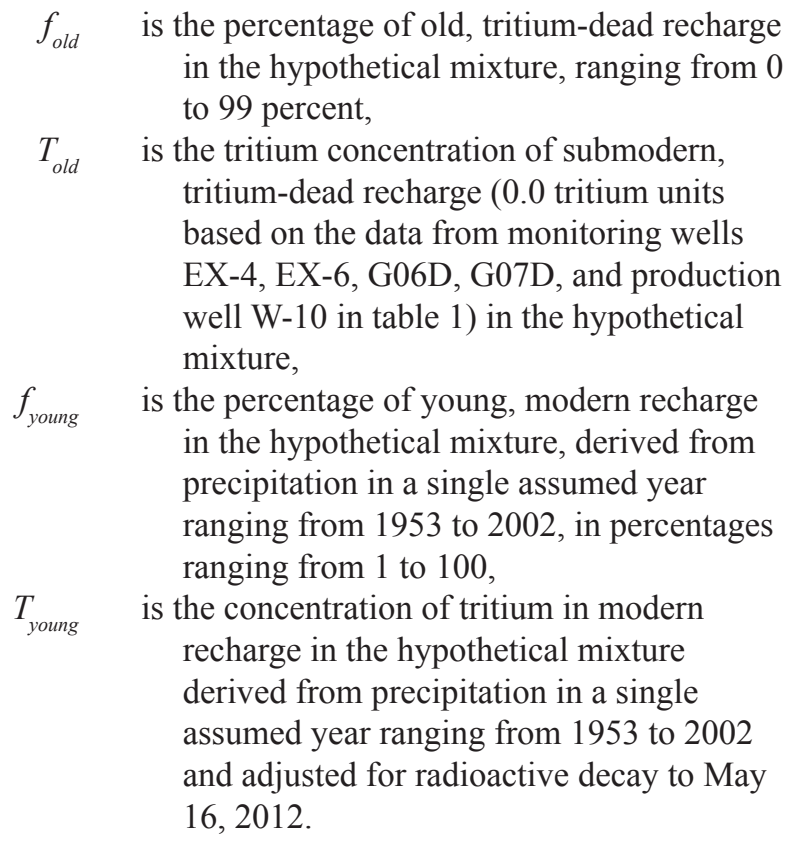

About 50 hypothetical mixtures were computed in this manner between the submodern, tritium dead recharge and recharge from each of the annual average, decay-corrected tritium concentrations for years from 1953-2002 (figs. $12 A-E$ ).
The two-part mixing models indicate that groundwater sampled by this study from monitoring well G53S was predominantly pre-1953 recharge and that if present, post-1955 recharge was less than 5 percent of groundwater sampled from that well (figs. $12 A-E$ ). The reported tritium concentration in the sample from monitoring well G53S was similar to two estimated tritium concentrations based on two-part mixtures of recharge: one mixture involved 20-percent 1953 recharge/ 80 -percent pre-1953 recharge, and a second mixture involved 10-percent 1955 recharge/90- percent pre-1953 recharge (fig. 12A). The youngest age of recharge that could have substantially contributed ( 5 percent or more) to hypothetical mixtures and yield an estimated tritium concentration similar to that from monitoring well G53S was from 1955. That age differed by about 3 years from the piston flow-defined age of recharge for this sample of no later than 1952. Hypothetical mixtures involving 5 percent or more of recharge from 19562002 with submodern, tritium-dead water had tritium concentrations greater than the tritium concentrations from the G53S sample.

The overall lack of detectable tritium in the six samples from this study with near-zero tritium concentrations is best explained as a physical absence of a post-1952 recharge contribution to groundwater in the lower part of the Radnor Till Member, the Organic Soil unit, or the Mahomet aquifer (table 1) and indicates the lack of groundwater-flow paths, fractures and macropores that could introduce post-1952 recharge to these units. Monitoring well G07S, screened in the Upper Radnor Till Sand and a deeper sand that may be the Lower Radnor Till Sand with a top of well screen depth of about $59 \mathrm{ft}$ below land surface, had a reported tritium concentration of $0.11 \pm 0.09 \mathrm{TU}$ (table 1), a very low concentration that indicates that recharge to this well dates from before 1953. The remaining four sampled monitoring wells EX-4, EX-6, G06D, and G07D, and production well W-10, all from stratigraphically deeper (by elevation) deposits than the Upper Radnor Till Sand, yielded samples with very low, near-zero tritium concentrations (TU values at or below the sample specific critical level, or levels below the laboratory analytical background, as indicated in table 1). With the exception of production well W-10, all groundwater samples from the Clinton site were collected from shallow permeable units that are within 70 feet of the surface at the Clinton site and within approximately 20 feet below the base of the Upper Radnor Till Sand.

Despite their proximity to the surface, the mixing analysis for all of the Lower Radnor Till Sand, the Organic Soil unit, as well as the Mahomet aquifer, indicates that groundwater contributing to these samples was pre-1953 recharge and was below the capability of the mixing analysis to indicate the potential presence of post-1952 recharge in the sample. For example, hypothetical mixtures of 2.5 percent of recharge from 1953 and 1955 yielded estimated tritium concentrations from about 0.1 to about $0.15 \mathrm{TU}$ (figs. $12 A-E$ ). All other 

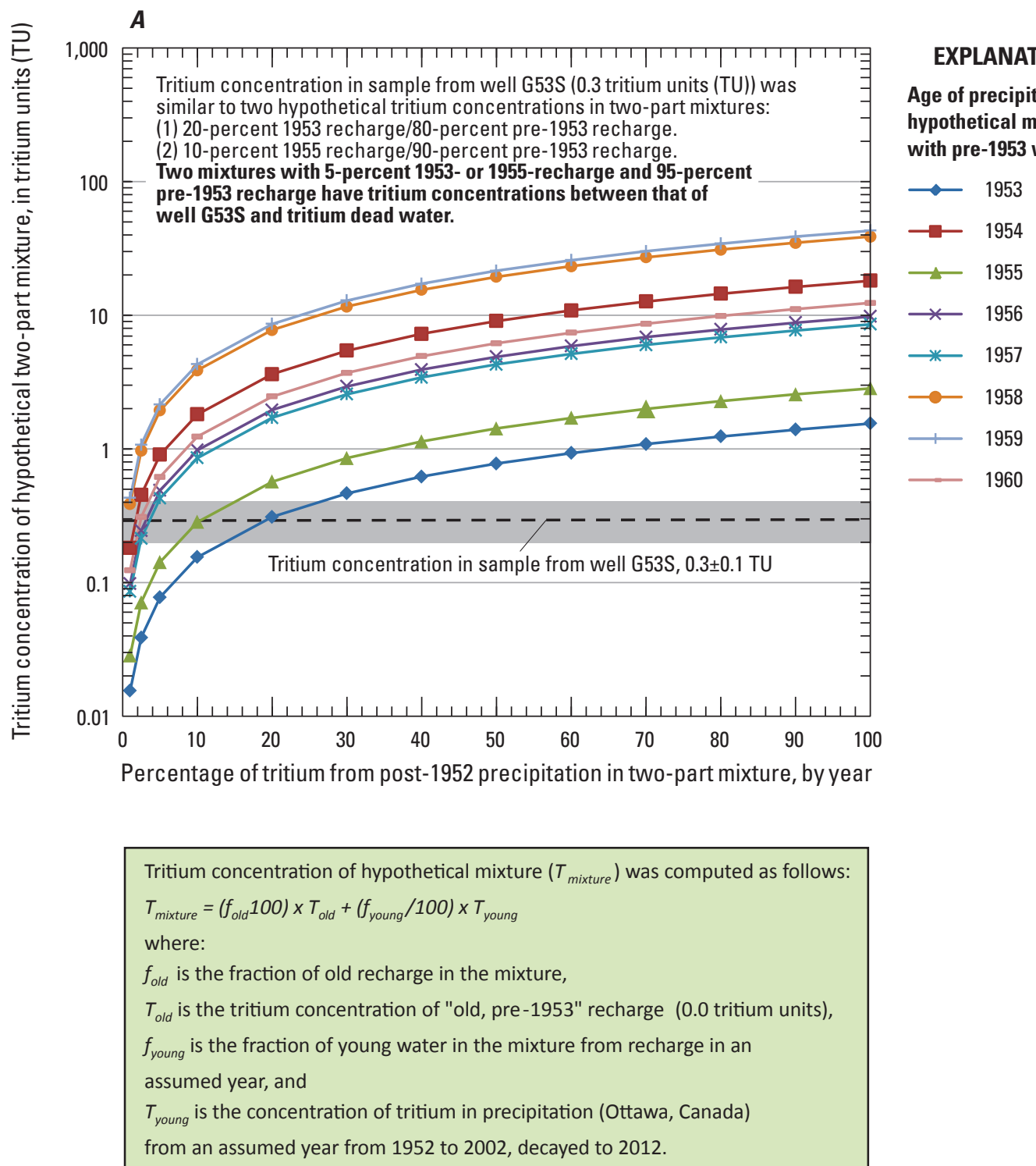

Figure 12. Mixing computations indicating differences and similarities between tritium in the sample from well G53S in the vicinity of Clinton landfill unit \#3, near Clinton, Illinois and hypothetical mixtures of pre-1953 recharge and 1953-2002 recharge. Plots used to indicate the likelihood of modern recharge in the sample: $A$, mixtures with 1953-1960 recharge; $B$, mixtures with 1961-69 recharge; $C$, mixtures with 1970-79 recharge; $D$, mixtures with 1980-89 recharge; and $E$, mixtures with 1990-2002 recharge.

hypothetical mixtures of 2.5 percent of recharge from 1954 or from each year from 1956-2002 with tritium dead water yielded estimated tritium concentrations that were greater than about $0.15 \mathrm{TU}$ (figs. $12 A-E$ ). When the 1-sigma precision of the tritium analyses was added to the tritium concentration from monitoring wells EX-4, EX-6, G06D, and G07D, and production well W-10 to represent the potential upper range of tritium concentration because of analytical variability, the upper range values of the 5 samples were less than the 0.15 TU threshold. This indicates that the presence of 2.5 percent or more by volume of recharge from 1954 or from 1956-2002 in these samples is not possible. The similarity of tritium concentrations in samples from monitoring wells EX-4, EX-6, G06D, and G07D, and production well W-10 to the 1-percent mixtures, and to the 2.5 percent mixtures involving 1953 and 1955 recharge also indicates that the mixing models could not distinguish the presence of very small amounts of modern recharge that are less than 2.5 percent of the total volume of groundwater samples with tritium concentrations that are less than $0.15 \mathrm{TU}$ or essentially zero. 


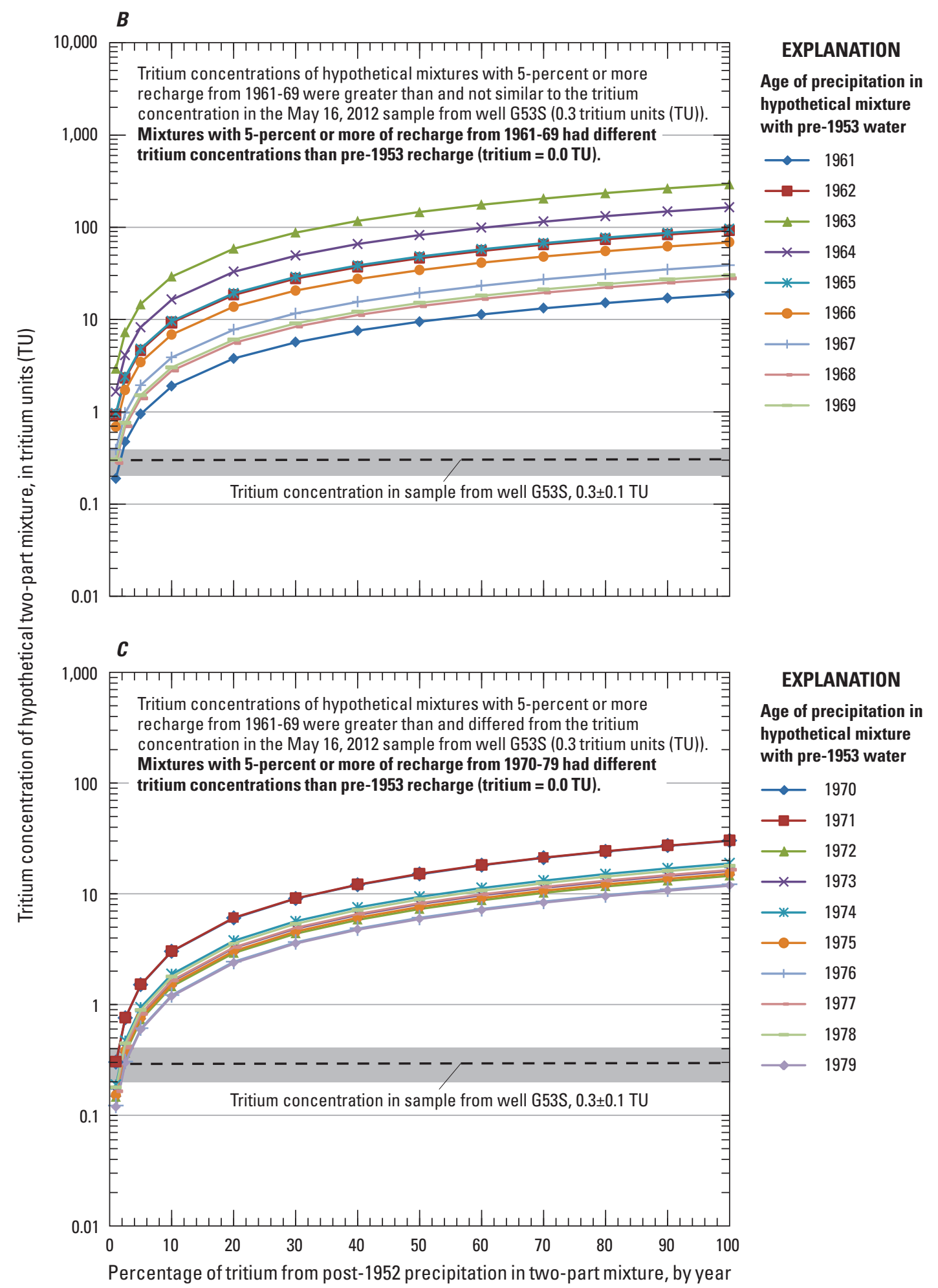

Figure 12. Mixing computations indicating differences and similarities between tritium in the sample from well G53S in the vicinity of Clinton landfill unit \#3, near Clinton, Illinois and hypothetical mixtures of pre-1953 recharge and 1953-2002 recharge. Plots used to indicate the likelihood of modern recharge in the sample: $A$, mixtures with 1953-1960 recharge; $B$, mixtures with 1961-69 recharge; $C$, mixtures with 1970-79 recharge; $D$, mixtures with 1980-89 recharge; and $E$, mixtures with 1990-2002 recharge.-Continued 


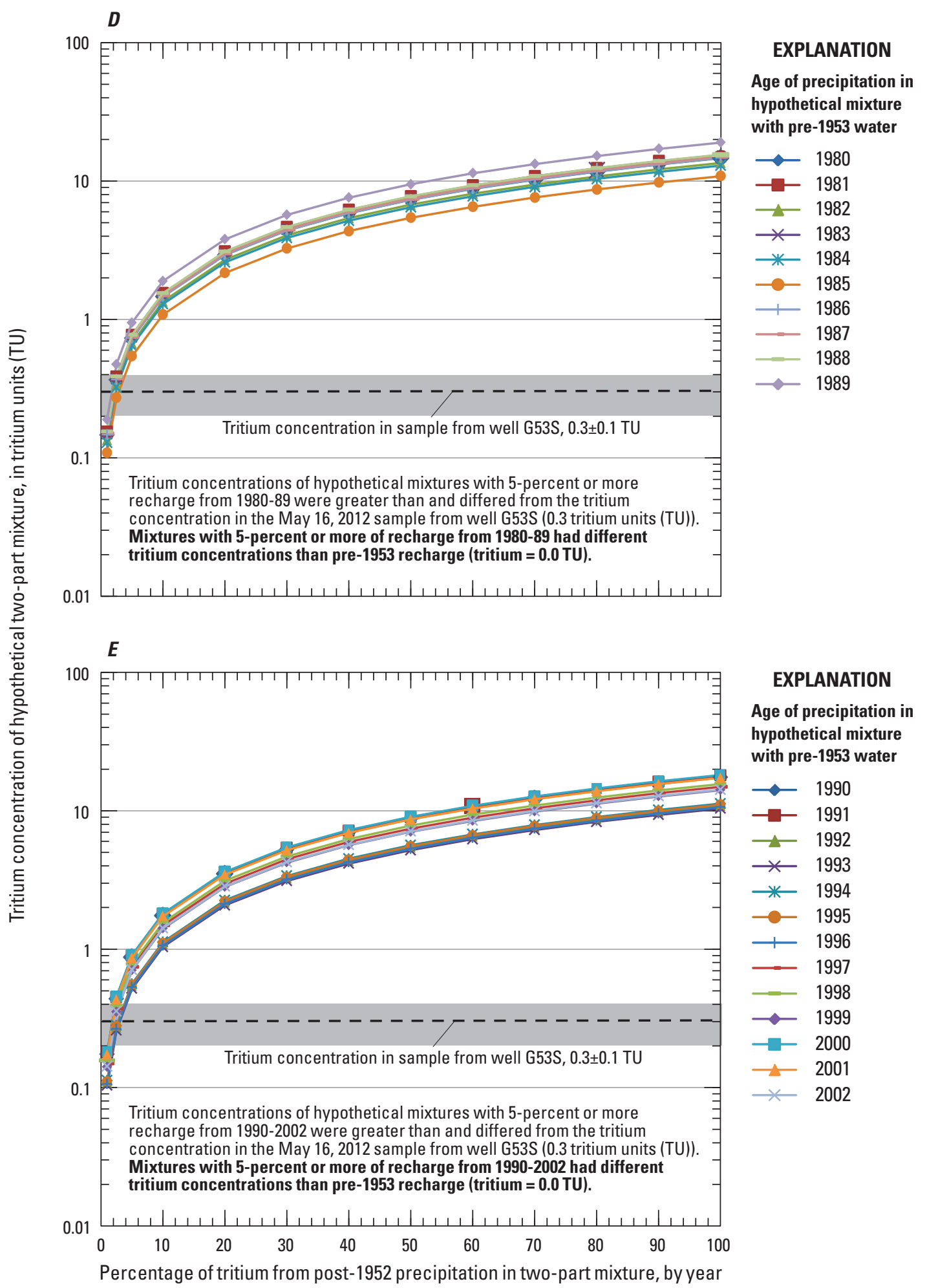

Figure 12. Mixing computations indicating differences and similarities between tritium in the sample from well G53S in the vicinity of Clinton landfill unit \#3, near Clinton, Illinois and hypothetical mixtures of pre-1953 recharge and 1953-2002 recharge. Plots used to indicate the likelihood of modern recharge in the sample: $A$, mixtures with 1953-1960 recharge; $B$, mixtures with 1961-69 recharge; $C$, mixtures with 1970-79 recharge; $D$, mixtures with 1980-89 recharge; and $E$, mixtures with 1990-2002 recharge.-Continued 


\section{Assessment of the Groundwater Travel Time at the Site of the Proposed Chemical Waste Unit}

Analysis of geologic and hydraulic data collected for a previous investigation of the Clinton site (PDC Technical Services, 2005) combined with the hydraulic and tritium data collected during this study indicate that low-permeability siltand-clay rich till deposits limit the downward flow of water from the land surface to the more permeable deposits within approximately $100 \mathrm{ft}$ of the land surface beneath the CWU and CLU\#3. Estimates of the vertical groundwater velocity $(\mathrm{Vv})$ and travel time through the geologic deposits between the base of the CWU and the top of the Mahomet aquifer were computed using (1) extrapolation of the tritium-based groundwater age at well G53S and (2) solution of the Darcy velocity equation (Gibb and others, 1984) for vertical groundwater velocity based on a variety of scenarios using site and regional data. The tritium-based estimate of vertical groundwater velocity through the section of glacial till between the base of the CWU and the Upper Radnor Till Sand was used with site and regional hydraulic conductivity data to estimate values of effective porosity $\left(n_{e}\right)$ in that interval. The $n_{e}$ estimates computed using site-specific and regional data also were compared with literature values of $n_{e}$ that represent the range of conditions described for glacial tills (Sara, 2003; Walton, 1984). The site-specific estimates and literature based estimate of $n_{e}$ were extrapolated across the entire thickness of glacial till and other deposits and used to compute estimates of vertical groundwater velocity and travel time from the base of the CWU to the Mahomet aquifer. These estimates of travel time were compared with indications of travel time from prior USGS widespread regional sampling of pesticide and tritium concentrations to understand potential limitations of this approach.

Solution of the Darcy velocity equation included scenarios using vertical hydraulic conductivity (Kv) values derived from triaxial permeability tests done on lithologic samples collected at CLU\#3. These site-specific tests previously reported by PDC Technical Services (2005) were considered to provide the best available data for $\mathrm{Kv}$ from the CLU\#3 site for this analysis at the time of this report. The $\mathrm{Vv}$ and travel time calculations using the triaxial permeability tests, along with the tritium-based values were used to estimate the range of vertical groundwater flow rates at CLU\#3.

Estimates of regional $\mathrm{Kv}$ values from Roadcap and others (2011) were used as comparisons to assess the suitability of the $n_{e}$ and $V v$ estimates computed from the $K v$ values derived from site triaxial permeability tests (PDC Technical Services, Inc., 2005), to identify potential data gaps, and to qualitatively supplement the assessment of hydrogeologic conditions below the CLU\#3 site. Estimates of Vv also included scenarios using $\mathrm{Kv}$ values for the till deposits of the Banner Formation (0.015 ft/yr), Glasford Formation $(0.037 \mathrm{ft} / \mathrm{yr})$, and Wedron Group $(0.37 \mathrm{ft} / \mathrm{yr})$ that were from a regional groundwater-flow model developed by Roadcap and others (2011). The regional $\mathrm{Kv}$ values have not been demonstrated to be valid at the CLU\#3 site. The Vv and travel time estimates based on regional values were applied to yield estimates of vertical groundwater flow rates for comparison to travel times computed with site-specific data.

Groundwater velocity calculations assume that groundwater flow was directed downward throughout the deposits above the Mahomet aquifer. Although water-level data indicate the potential for downward flow from the Upper Radnor Till Sand, Lower Radnor Till Sand, and the Organic Soil unit to the Mahomet aquifer beneath all of CLU\#3, and from the Upper Radnor Till Sand to the Lower Radnor Till Sand to the Organic Soil unit beneath most of the CLU\#3 area, the potential for upward flow from the Organic Soil unit to the Upper Radnor Till Sand has been demonstrated by the water-level data southeast of CLU\#3 at the EX-22 well cluster. A temporary or transient vertically upward flow would delay downward flow from the proposed location of the CWU to the Mahomet aquifer by increasing the overall travel time across that interval.

\section{Vertical Groundwater Travel Time Estimated at the Clinton Site Using Tritium-Age Based Groundwater Velocity}

The low tritium detection from one of the two monitoring wells screened in the Upper Radnor Till Sand indicates that recharge takes a minimum of about 59 years to flow from land surface to a comparatively shallow (50 ft from land surface) part of the Upper Radnor Till Sand. From this information it is concluded that the $\mathrm{Vv}$ through the deposits above the Upper Radnor Till Sand was $0.85 \mathrm{ft} / \mathrm{yr}$ or less. These deposits include the sand deposits and the till deposits above the Upper Radnor Till Sand, but the Vv is likely to be most affected by the large transit time through the till.

If the maximum $\mathrm{Vv}$ of $0.85 \mathrm{ft} / \mathrm{yr}$ determined above also is assumed to uniformly apply beneath the CWU and CLU\#3, a minimum of 200 years is needed for water to flow the approximately $170 \mathrm{ft}$ from the top of the Berry Clay Member (the top of which is immediately below the CWU and at an altitude of about $660 \mathrm{ft}$ NAVD 88) to the top of the Mahomet aquifer at about $489 \mathrm{ft}$ NAVD 88 (PDC Technical Services, Inc., 2005). This calculated minimum time of travel assumes the Vv through the deposits above the Upper Radnor Till Sand is equal to or less than the $\mathrm{Vv}$ through the deposits from the Berry Clay Member to the Mahomet aquifer.

Tritium was at near zero concentrations in samples from the second well screened in the Upper Radnor Till Sand and from wells that were open to the Lower Radnor Till Sand, the Organic Soil unit, or the Mahomet aquifer in the vicinity of CLU\#3. The Lower Radnor Till Sand and the Organic Soil unit are within approximately 20 feet of the base of the Upper Radnor Till Sand, whereas the top of the Mahomet aquifer is approximately 160 feet below the Upper Radnor Till Sand. The data indicate submodern water in the Upper Radnor Till Sand, Lower Radnor Till Sand, Organic Soil unit, and the Mahomet aquifer. The lack of tritium in groundwater samples 
from the Lower Radnor Till Sand, the Organic Soil unit, and the Mahomet aquifer is consistent with the 200-year travel time estimate from the top of the Berry Clay Member to the top of the Mahomet aquifer. The low tritium detection in one of the two samples collected from the Upper Radnor Till Sand, the very low, near zero tritium concentration in the second Upper Radnor Till Sand sample and the near absence of detectable tritium in all the deeper units indicates a uniformity in the hydraulic behavior in the till and supports the use of the piston flow model to represent vertical groundwater flow at the Clinton site.

\section{Vertical Groundwater Travel Time Using Estimates of Effective Porosity and Darcy Velocity}

A second method used to estimate the time of travel from the base of the proposed CWU to the top of the Mahomet aquifer was through the solution of the Darcy velocity equation (3) using site hydrogeologic data. Application of this method to estimate travel time at the CLU\#3 and the CWU involved two steps.

Step 1 of this approach computed estimates of effective porosity $\left(\mathrm{n}_{\mathrm{e}}\right)$ using the maximum vertical velocity of groundwater from land surface to the Upper Radnor Till Sand, as estimated from the tritium-based analysis of the sample from G53S and extrapolated to the entire section above the Mahomet aquifer. A rearranged form of the Darcy velocity equation (3) was applied to estimate the $n_{e}$ of various units using parameter values that included the maximum vertical velocity $\left(\mathrm{Vv}_{\mathrm{T}}\right)$, measured vertical hydraulic gradients $(\mathrm{dh} /$ dl) and measured and reported values of vertical hydraulic conductivity $(\mathrm{Kv})$.

$$
n_{e}=K v\left(1 / V v_{T}\right) *(d h / d l)
$$

Where

$n_{e} \quad$ is the effective porosity of the deposit through which flow is transmitted,

$V v_{T} \quad$ is the maximum vertical velocity of groundwater, as estimated from the tritiumbased analysis of the sample from G53S,

$K v \quad$ is the vertical hydraulic conductivity of the deposit through which flow is transmitted,

$d h \quad$ is the change in water level over the vertical distance being considered, and

$d l \quad$ is the vertical distance over which dh is measured.

In step 2, the vertical groundwater velocity $(\mathrm{Vv})$ was then recalculated specifically for the glacial units between the base of the proposed chemical waste unit (Berry Clay Member) and the top of the Mahomet aquifer using a rearranged version of the Darcy velocity equation (4). The Vv was computed using a range of values for $\mathrm{Kv}$ and $\mathrm{n}_{\mathrm{e}}$ from the site-specific estimates and published literature.

$$
V v=K v\left(1 / n_{e}\right)(d h / d l)
$$

Where

Vv is the vertical velocity of groundwater and the other parameters are the same as defined for equation (3).

Step 1, solving equation 3 for the $n_{e}$ of the deposits above the Upper Radnor Till Sand, involves the following assumptions and data.

- The $\mathrm{Vv}$ in equation 4 was assumed to be $0.85 \mathrm{ft} / \mathrm{yr}$ for the deposits above the Upper Radnor Till Sand. This was the maximum vertical groundwater velocity based on the groundwater age in the Upper Radnor Till Sand determined from the concentration of tritium in the Upper Radnor Till Sand at monitoring well G53S. The actual range of $\mathrm{Vv}_{\mathrm{v}}$ values in deposits above the Upper Radnor Till Sand is likely to be comparable or lower than the assumed Vv.

- The pre-excavation water table elevation in this area is $700 \mathrm{ft} \mathrm{NAVD} 88$ based on data from lithologic logs (PDC Technical Services, Inc., 2005). The water level used to represent the Upper Radnor Till Sand was $661.54 \mathrm{ft}$ NAVD 88 from monitoring well G53S (table 1). These values yield $\mathrm{dh}=700-661.54$.

- The vertical distance over which the water levels were measured (dl) is the difference between the approximate water table (700 ft NAVD 88) and the elevation of the top of the Upper Radnor Till Sand at boring EX21S/well G53S of $650 \mathrm{ft}$ NAVD 88 (fig. 4), or $\mathrm{dl}=700-650$. The elevation of the Upper Radnor Till Sand was used for the estimate because the water level in monitoring well G53S is likely to represent the hydraulic head in the most permeable deposit intersected by the well screen (the Upper Radnor Till Sand), rather than the hydraulic head in the less permeable silt- and-clay rich till within the rest of the well screen, according to the principle described by Sokol (1963).

Values used to represent the $\mathrm{Kv}$ of the deposits above the Upper Radnor Till Sand in computations of $\mathrm{n}_{\mathrm{e}}$ include the following:

- A geometric mean of $\mathrm{Kv}$ of $0.027 \mathrm{ft} / \mathrm{yr}$ computed from all triaxial test data on sediment cores of silt and clay deposits from the site (PDC Technical Services, Inc., 2005),

- A geometric mean of $\mathrm{Kv}$ of $0.034 \mathrm{ft} / \mathrm{yr}$ computed from triaxial test data on sediment cores from the Berry Clay Member and Glasford Formation at the site (PDC Technical Services, Inc., 2005), and 


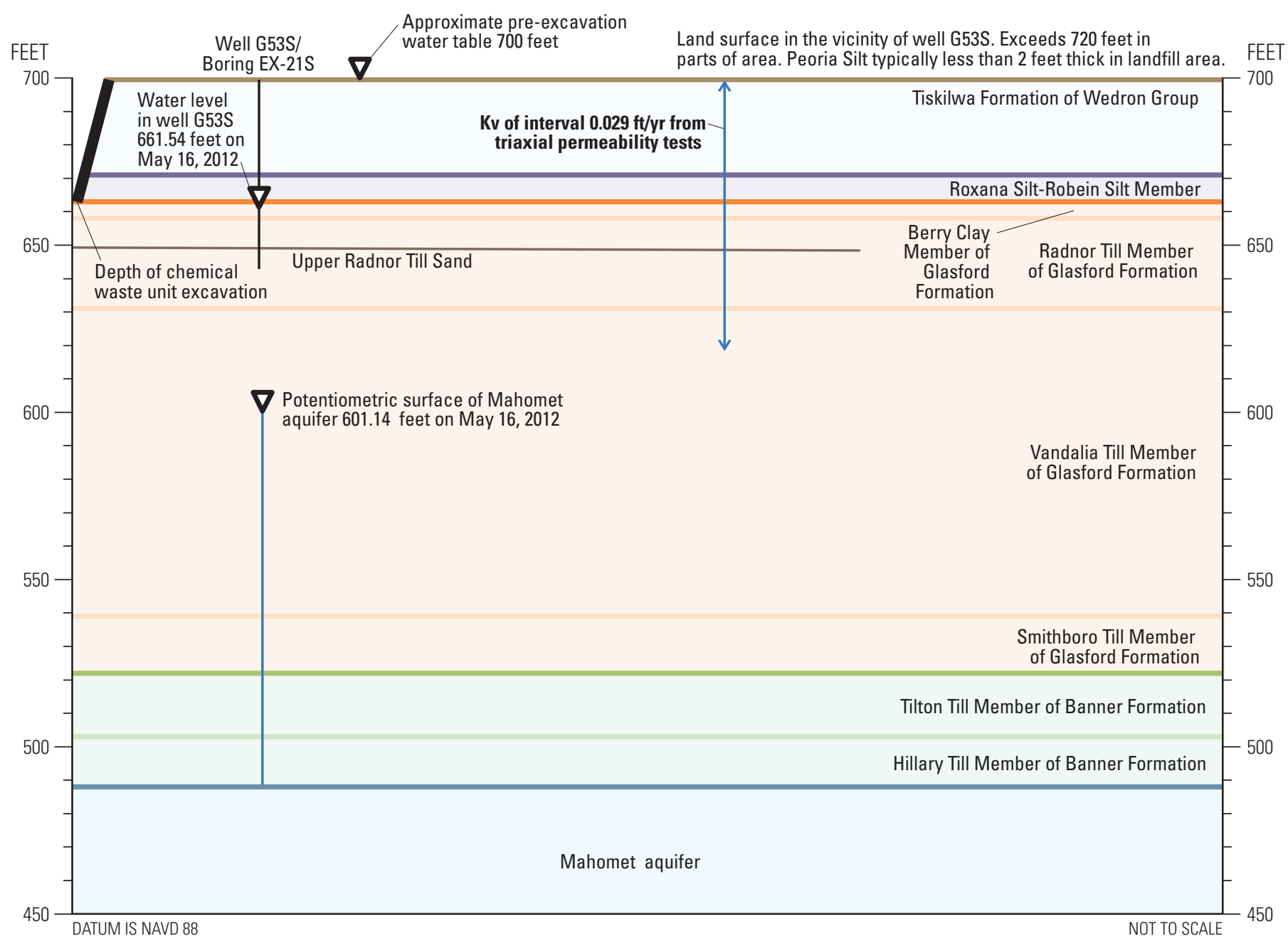

EXPLANATION

Kv $0.029 \mathrm{ft} / \mathrm{yr} \quad$ Vertical hydraulic conductivity of deposit, and value, in feet per year (ft/yr)

Figure 13. Conceptual diagram of features and data used in the solution of the Darcy velocity equation according to scenario one for the deposits at Clinton landfill unit \#3, near Clinton, Illinois.

- A Kv of $0.37 \mathrm{ft} / \mathrm{yr}$ used by Roadcap and others (2011) to represent the Wedron Group tills in their regional simulation of groundwater flow in the Mahomet aquifer. This $\mathrm{Kv}$ was used for $\mathrm{n}_{\mathrm{e}}$ estimation because the tritium data used to evaluate recharge age included vertical flow through the Wedron Group tills. The Kv of Wedron Group tills was not used to evaluate vertical velocity and travel time in later computations because the Wedron Group tills were excavated to accommodate the landfill (fig. 6).

- Because the Vv used in this analysis ( $0.85 \mathrm{ft} / \mathrm{yr})$ was the maximum value based on the analysis of the available tritium concentrations, the $\mathrm{n}_{\mathrm{e}}$ values calculated using step 1 outlined above were considered to be the minimum values for any given $\mathrm{Kv}$ value.
Step 2, solving equation 3 for the Vv through the till deposits between the Upper Radnor Till Sand and the top of the Mahomet aquifer (table 2; fig. 13), involved the following assumptions and data:

- Effective porosity values for the deeper till deposits between the Upper Radnor Till Sand and the top of the Mahomet aquifer were assumed to equal the $n_{e}$ values calculated in step 1 for the shallower deposits above the Upper Radnor Till Sand.

- The water level in monitoring well G53S on July 12 , 2012 was used to represent water levels in the Upper Radnor Till Sand and the water level in production well W-10 on the same date was used to represent water levels at the top of the Mahomet aquifer. This 
Table 2. Estimates of effective porosity computed using the Darcy velocity equation with a tritium-based vertical groundwater velocity and vertical hydraulic conductivity values from the Clinton site, near Clinton, Illinois and from Roadcap and others (2011).

[Underline denotes calculated value, normal text denotes measured value; NAVD 88, North American Vertical Datum of 1988]

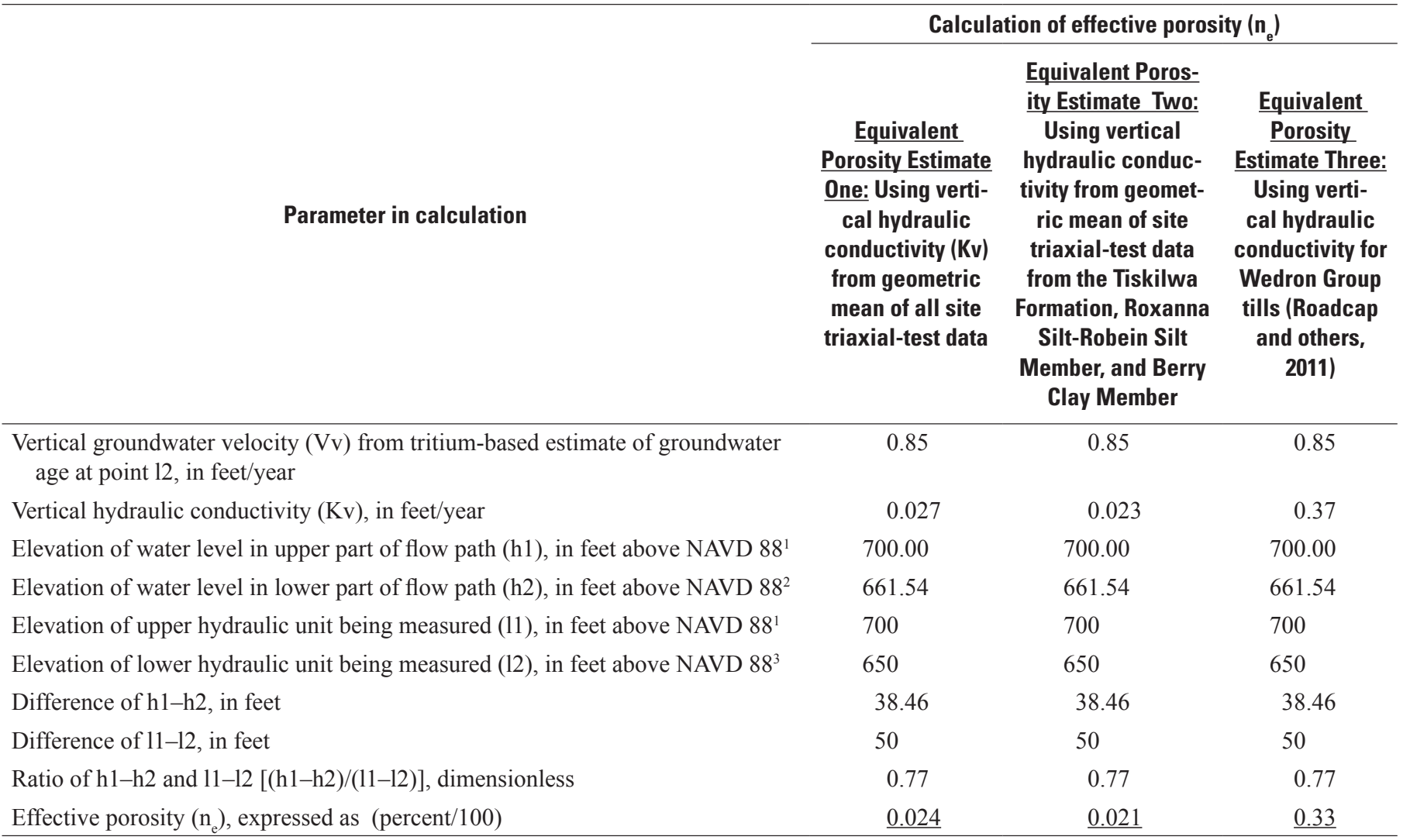

${ }^{1}$ Elevation of water level in upper part of flow path (h1) and elevation of upper hydraulic unit being measured (11) values of 700 feet above NAVD 88 based on approximate altitude of water table.

${ }^{2}$ Elevation of water level in lower part of flow path (h2) value of 661.54 feet above NAVD 88 based on water level in well G53S on May 16, 2012.

${ }^{3}$ Elevation of lower hydraulic unit being measured (12) value of 650 feet above NAVD 88 based on altitude of upper Radnor Till sand at well G53S.

result yielded $\mathrm{dh}=661.54-601.14$. Monitoring well G53S was chosen for this analysis because data from this well was used in the calculation of $n_{e}$, it is the sampled well that is closest to the CWU, and it monitors the Upper Radnor Till Sand. The Upper Radnor Till Sand is the monitored deposit nearest the Berry Clay Member and the base of the CWU. This use of the water level in production well W-10 to represent conditions at the top of the Mahomet aquifer was based on a simplifying assumption of a minimal vertical hydraulic gradient and predominantly horizontal flow in the aquifer. The assumption was made in the absence of local data on vertical flow in the Mahomet aquifer.

- The elevation of the upper hydraulic unit being measured (11) is $650 \mathrm{ft}$ NAVD 88, based on the altitude of the Upper Radnor Till Sand at boring EX-21D/well G53S (fig. 4). The elevation used to represent the top of the Mahomet aquifer/bottom of the till (12) was $489 \mathrm{ft}$ NAVD 88 from boring EX-30 (fig. 4). This result yielded $\mathrm{dl}=650-489 \mathrm{ft}$.
Various values were used for $\mathrm{Kv}$ of the till deposits from the Berry Clay Member to the top of the Mahomet aquifer. These included the two Kv values derived from triaxial test data previously described in Step 1, and additional Kv values of $0.037 \mathrm{ft} / \mathrm{yr}$ used to represent Glasford Formation tills and $0.015 \mathrm{ft} / \mathrm{yr}$ used to represent the Banner Formation tills in a regional simulation of the Mahomet aquifer by Roadcap and others (2011). Once the Vv through the till deposits between the Upper Radnor Till Sand and the top of the Mahomet aquifer was calculated, travel time through the deposits below the CWU (Berry Clay Member to top of Mahomet aquifer) was determined by dividing the thickness of the till deposits in this interval $(155 \mathrm{ft}$ ) by the calculated $\mathrm{Vv}$. Each travel time is presented in the report as a minimum number of years, as computed and rounded to the nearest two significant figures. Because the tritium-based Vv for the deposits above the Upper Radnor Till Sand was considered to be a maximum value, the $\mathrm{n}_{\mathrm{e}}$ values based on this $\mathrm{Vv}$ were therefore minimum values. The true $\mathrm{Vv}$ from the Berry Clay to the top of the Mahomet aquifer is likely to be lower than the calculated value, with a 
Table 3. Estimates of vertical groundwater velocity and groundwater travel time for the Clinton site, near Clinton, Illinois by solution of the Darcy velocity equation using selected values of vertical hydraulic conductivity and equivalent porosity from scenarios in table 2 and vertical hydraulic conductivity from Roadcap and others (2011).

[Underline denotes calculated value, normal text denotes measured value; Bold values denote values used to represent groundwater NAVD 88, North American Vertical Datum of 1988; groundwater travel time estimates are rounded to the nearest two significant figures]

Calculation of vertical groundwater velocity and groundwater travel time

\begin{tabular}{|c|c|c|}
\hline & Calcı & on of vertical ground \\
\hline Parameter in calculation & $\begin{array}{l}\text { Scenario One: } \\
\text { From the top of } \\
\text { the Berry Clay } \\
\text { Member to the } \\
\text { top of Mahomet } \\
\text { aquifer using } \\
\text { equivalent } \\
\text { porosity from } \\
\text { Scenario one } \\
\text { (table } 2 \text { ) and } \\
\text { vertical hydrau- } \\
\text { lic conductivity } \\
\text { from geometric } \\
\text { mean of all site } \\
\text { triaxial-test } \\
\text { data }\end{array}$ & $\begin{array}{l}\text { Scenario Two: From } \\
\text { the top of the Berry } \\
\text { Clay Member to the } \\
\text { top of the Ma- } \\
\text { homet aquifer using } \\
\text { equivalent poros- } \\
\text { ity from Scenario } \\
\text { two (table 2) and } \\
\text { vertical hydraulic } \\
\text { conductivity from } \\
\text { geometric mean } \\
\text { of site triaxial-test } \\
\text { data from the Berry } \\
\text { Clay Member and } \\
\text { Glasford Formation' }\end{array}$ \\
\hline
\end{tabular}


proportionally greater travel time. A small additional travel time represented in days also was computed to represent vertical groundwater flow through the combined $15 \mathrm{ft}$ of sand and gravel deposits between the Berry Clay Member and the top of the Mahomet aquifer.

Analysis of hydraulic data and triaxial test data from the Clinton site, constrained by a tritium-age based maximum groundwater velocity estimate, computed minimum estimates of effective porosity ( $n_{\mathrm{e}}$ ) that range from about 0.021 to 0.024 for the predominantly till deposits above the Mahomet aquifer (table 2). The three estimates of $n_{e}$ derived by this study (0.024, 0.021 and 0.33; table 2) from Clinton site data and the regional value of $\mathrm{Kv}$ from Roadcap and others (2011) were within or slightly greater than the published ranges of $\mathrm{n}_{\mathrm{e}}$ values in sediments with similar textures (Sara, 2003, table 5-8, p. 315). Sara (2003) reports $n_{\mathrm{e}}$ values for clay that range from 0.01 to 0.2 , silt that range from 0.01 to 0.3 and glacial sediments that range from 0.05 to 0.2 (Sara, 2003; Walton 1984). Smaller values of $n_{e}$ are considered conservative for the purpose of estimating vertical groundwater velocity because $\mathrm{n}_{\mathrm{e}}$ is inversely proportional to $\mathrm{Vv}$ in the Darcy velocity equation. By comparison, the total porosity values reported for 9 tests of the Berry clay from the Clinton site ranged from 0.235 to 0.379 with a mean value of 0.325 and for 9 tests of the Radnor Till from the Clinton site ranged from 0.194 to 0.446 with a mean value of 0.248 (PDC Technical Services, Inc., 2005). These total porosity values from the Clinton site were larger than the estimates one and two of $\mathrm{n}_{\mathrm{e}}$ derived by this study (0.024 and 0.021; table 2). Sara (2003, table 5-8, p. 315) reports published ranges of total porosity of 0.34 to 0.6 for clay and 0.34 to 0.61 for silt; no comparable range was reported by Sara (2003) for glacial sediments. Effective porosity $\left(n_{e}\right)$ is typically less than total porosity because $n_{e}$ represents interconnected pore space through which water and fluids can pass and does not include the part of total porosity that describes static water and fluids that are bound to mineral surfaces in pore spaces (Sara, 2003, p. 313). Effective porosity, in general, can be more than one order of magnitude smaller than total porosity with the largest difference in fractured materials (Domenico and Schwartz, p. 25). This study therefore uses the estimates of $n_{e}$ in table 2 derived by this study to estimate the possible range of vertical groundwater velocity at the Clinton site.

\section{Scenario One, Vertical Hydraulic Conductivity Equal to Geometric Mean of all Site Triaxial Permeability Tests}

The geometric mean value of $\mathrm{Kv}$ from the triaxial permeability tests done on 29 silt and clay samples collected from 623 through $703 \mathrm{ft}$ NAVD 88 at CLU\#3 was 0.027 feet per year (ft/yr; units converted from PDC Technical Services, Inc., 2005). Using this value of Kv, and the parameters given for solution of the Darcy velocity equation previously outlined in step 1 (fig. 13), $\mathrm{n}_{\mathrm{e}}$ was calculated to be no less than 0.024 for the predominantly silt-and-clay rich till deposits above the Upper Radnor Till Sand (table 2). This calculated $n_{e}$ value is less than the lower end of reported values for glacial till $(0.05$ to 0.2 ) but generally consistent with the lower end of reported values for silt (0.01 to 0.3$)$ and clay (0.01 to 0.2$)$ according to Sara (2003) and Walton (1984). A smaller value of $n_{e}$ yields a higher estimate of vertical groundwater velocity. A smaller value of $n_{e}$ therefore provides a more conservative estimate of groundwater travel time.

Triaxial permeability tests, however, can underestimate the field-scale $\mathrm{Kv}$ of till deposits, primarily because of the small scale of the triaxial permeability measurements in comparison to the field scale of permeable features (Stephenson and others, 1988; Bradbury and Muldoon, 1990; Herzog and Morse, 1986). Because the values of $\mathrm{Vv}$ and $\mathrm{dh} / \mathrm{dl}$ in equation 3 were independently known (fixed) in the application of step 1 , any variation in the value of $\mathrm{Kv}$ will result in a directly proportionate variation in the value of $n_{e}$. If the true $\mathrm{Kv}$ of glacial till and other deposits above the Upper Radnor Till Sand at CLU\#3 is greater than the $\mathrm{Kv}$ indicated by the geometric means computed from triaxial permeability tests, the true $n_{e}$ of these deposits would be greater than the minimum estimates of $\mathrm{n}_{\mathrm{e}}$ of 0.021 and 0.024 .

Using the $\mathrm{n}_{\mathrm{e}}$ of 0.024 , a Kv of $0.027 \mathrm{ft} / \mathrm{yr}$, and the parameters given for solution of the Darcy velocity equation as previously outlined in step 2 (fig. 13), the Vv between the Upper Radnor Till Sand and the Mahomet aquifer was calculated to be no more than $0.41 \mathrm{ft} / \mathrm{yr}$ (table 3 ). If this $\mathrm{Vv}$ is representative of the deposits below the CWU, it should take a minimum of about 370 years for water to flow through the $155 \mathrm{ft}$ of silt and clay present from the Berry Clay Member to the top of the Mahomet aquifer (fig. 13; table 3). Note that if the actual $n_{e}$ of the deposits above (and below) the Upper Radnor Till Sand is greater than the 0.024 assumed $\mathrm{Vv}$, the true $\mathrm{Vv}$ will be less than $0.41 \mathrm{ft} / \mathrm{yr}$ and the true time of travel from the Berry Clay Member to the Mahomet aquifer will exceed the estimated minimum of 370 years.

The additional groundwater-transit time required for the $15 \mathrm{ft}$ of sand between the top of the Berry Clay Member and the top of the Mahomet aquifer was calculated by solving equation 3 for $\mathrm{Vv}$ and assuming values for $\mathrm{dh}$ and $\mathrm{dl}$ based on data for monitoring well G53S and the top of the Mahomet aquifer previously outlined; a Kv of $1.2 \times 10^{4} \mathrm{ft} / \mathrm{yr}$ (Roadcap and others, 2011), and an $n_{e}$ of 0.2 (Walton, 1984). The calculated $\mathrm{Vv}$ using these parameters exceeded 24,000 ft/yr and the total transit time through the sand deposits was calculated to be less than 1 day.

\section{Scenario Two, Vertical Hydraulic Conductivity Equal to Geometric Mean of Site Triaxial Permeability Tests Above the Upper Radnor Till Sand and Below the Roxana Silt- Robein Silt Member}

Because the age of groundwater indicated by the concentration of tritium in the Upper Radnor Till Sand at monitoring well G53S provided the foundation for the maximum vertical velocity $\left(\mathrm{Vv}_{\mathrm{T}}\right)$ estimate, and because this water migrates through the Tiskilwa Formation, the Roxana Silt-Robein Silt Member, and the Berry Clay Member before entering the 


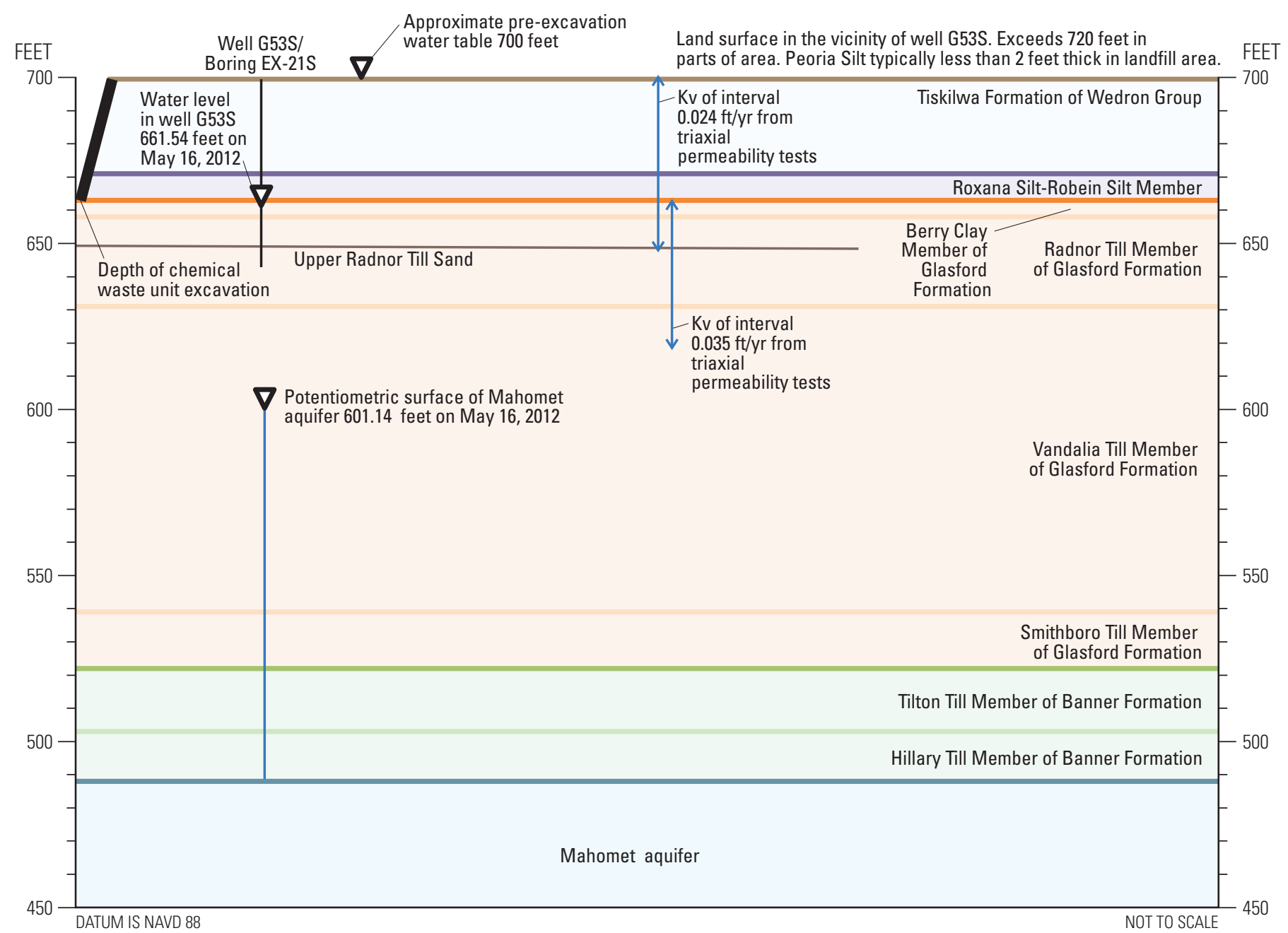

\section{EXPLANATION}

Kv $0.024 \mathrm{ft} / \mathrm{yr} \quad$ Vertical hydraulic conductivity of deposit, and value, in feet per year (ft/yr)

Figure 14. Conceptual diagram of features and data used in the solution of the Darcy velocity equation according to scenario two for the deposits at Clinton landfill unit \#3, near Clinton, Illinois.

Upper Radnor Till Sand, equation 3 also was solved for $n_{e}$ using a Kv equal to the geometric mean value of 19 triaxial permeability tests of samples collected from the deposits above the Upper Radnor Till Sand ( $0.023 \mathrm{ft} / \mathrm{yr}$; units converted from PDC Technical Services, Inc., 2005) at CLU\#3 (fig. 14). The $n_{e}$ was calculated to be 0.021 (table 2).

The Vv from the top of the Berry Clay Member to the top of the Mahomet aquifer then was calculated by solving equation 3 using the $n_{e}$ of 0.021 and $\mathrm{Kv}$ equal to the geometric mean value of 19 triaxial permeability tests of samples collected from the Berry Clay Member, the Radnor Till Member, and the Vandalia Till Member at CLU\#3 (0.034 ft/yr; units converted from PDC Technical Services, Inc., 2005; table 3). No triaxial permeability tests were done using deposits below the Vandalia Till Member. The calculated (maximum) Vv was $0.61 \mathrm{ft} / \mathrm{yr}$, indicating an estimated minimum of 260 years for groundwater to flow from the top of the Berry Clay Member to the top of the Mahomet aquifer (table 3).

\section{Scenario Three, Vertical Hydraulic Conductivity Equal} to Values for Tills of the Wedron Group and Glasford Formation from Regional Groundwater Flow Model

The till deposits of the Wedron Group at CLU\#3 are composed of the Tiskilwa Formation and constitute most of the deposit above the Upper Radnor Till Sand (figs. 6, 15). Solving equation 3 for $\mathrm{n}_{\mathrm{e}}$ of the deposits above the Upper Radnor Till Sand using the model-derived Kv (Roadcap and others, 2011) value for the till deposits of the Wedron Group resulted in an $n_{e}$ value of 0.33 (table 2 ). This value exceeds the range of laboratory-measured total porosity values $(0.23$ to 0.28$)$ for seven samples collected from the Tiskilwa Formation of 


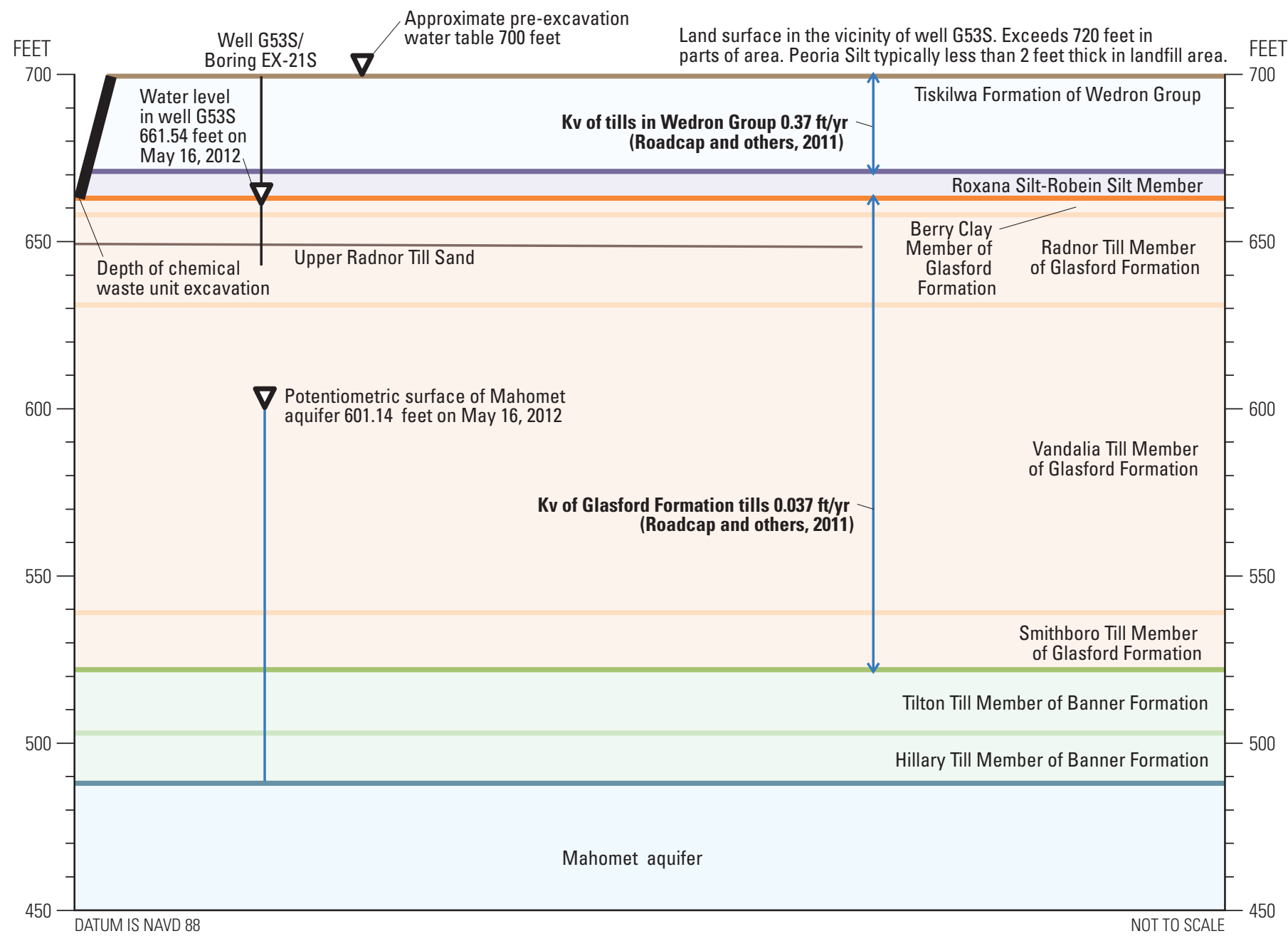

EXPLANATION

Kv $0.037 \mathrm{ft} / \mathrm{yr} \quad$ Vertical hydraulic conductivity of deposit, and value, in feet per year (ft/yr)

Figure 15. Conceptual diagram of features and data used in the solution of the Darcy velocity equation according to scenario three for the deposits at Clinton landfill unit \#3, near Clinton, Illinois.

the Wedron Group at CLU\#3 (PDC Technical Services, Inc., 2005) and literature-based values of $n_{e}$ for glacial till, clay, and silt (Walton, 1984). Because $n_{e}$ typically is much less than the total porosity, an $n_{e}$ of 0.33 is considered improbably high for these deposits, indicating that the model-derived $\mathrm{Kv}$ for the till deposits of the Wedron Group (at least as a representation of all the deposits above the Upper Radnor Till Sand) also is improbably high at CLU\#3. The calculated Vv of $0.041 \mathrm{ft} / \mathrm{yr}$ from the top of the Berry Clay Member to the top of the Mahomet aquifer, based on this $n_{e}$ and the modelderived $\mathrm{Kv}$ for the till in the Glasford Formation (fig. 15; table 2) is therefore considered a low estimate.

The Kv of the Glasford Formation was used in the calculation of $\mathrm{Vv}$ and travel time because it constitutes most of the till between the CWU and the Mahomet aquifer. The calculated (maximum) Vv was $0.041 \mathrm{ft} / \mathrm{yr}$, indicating that with this set of conditions it would take an estimated minimum of 3,700 years for groundwater to flow through from the top of the Berry Clay Member to the top of the Mahomet aquifer (table 3). Because of the limitations indicated above, the calculated vertical velocity and travel time in Scenario three were considered unrealistically long and were not used to represent travel times.

\section{Scenario Four, Vertical Hydraulic Conductivity Equal to Value for Glasford Formation Tills From Regional Groundwater Flow Model}

The $n_{e}$ of 0.021 based on the Kv from site triaxial permeability tests of the Tiskilwa Formation, Roxana Silt-Robein Silt Member, and Berry Clay Member (PDC Technical 


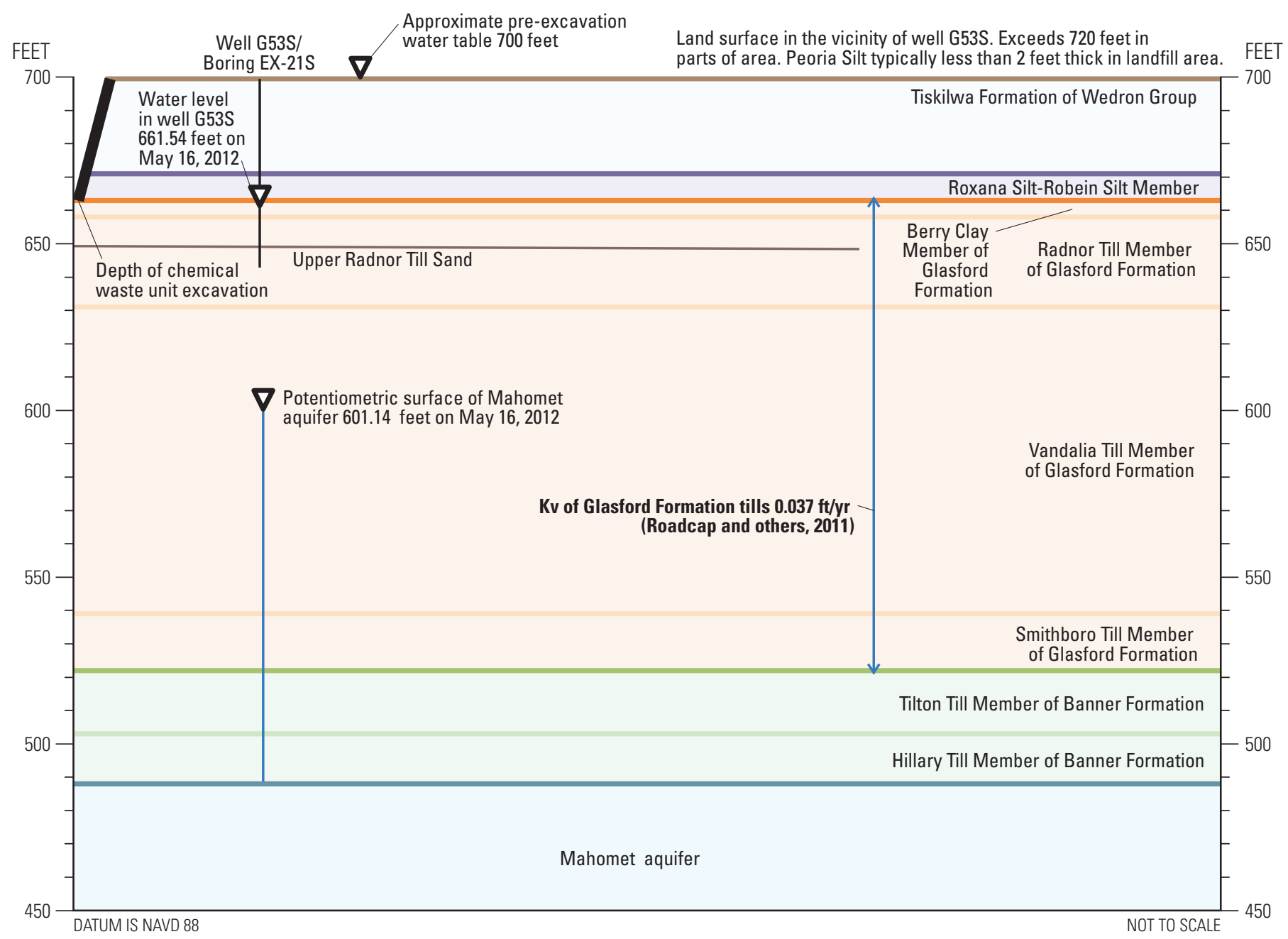

EXPLANATION

Kv $0.037 \mathrm{ft} / \mathrm{yr} \quad$ Vertical hydraulic conductivity of deposit, and value, in feet per year (ft/yr)

Figure 16. Conceptual diagram of features and data used in the solution of the Darcy velocity equation according to scenario four for the deposits at Clinton landfill unit \#3, near Clinton, Illinois.

Services, Inc., 2005) was used to represent the Glasford Formation (table 2); an approach that was consistent with that used for scenario two. Using the Kv value of the Glasford Formation to solve equation 3 for the $n_{e}$ of the deposits above the Upper Radnor Till Sand is not appropriate because most of the deposits above the Upper Radnor Till Sand are not part of the Glasford Formation (figs. 6 and 16). This is the lowest $n_{e}$ value determined for the Clinton site, which will result in the highest calculated Vv and the shortest travel time. The model-derived regional Kv (Roadcap and others, 2011) for the till of the Glasford Formation ( $0.037 \mathrm{ft} / \mathrm{yr}$; table 3$)$ is similar to the geometric mean $\mathrm{Kv}$ value of the triaxial permeability tests done in samples collected from the Glasford Formation at CLU\#3 $(0.034 \mathrm{ft} / \mathrm{yr})$, resulting in a similar calculated $\mathrm{Vv}$ (maximum $0.66 \mathrm{ft} / \mathrm{yr}$, table 3 ). The similarity in $\mathrm{Kv}$ values computed from Scenarios Two and Four indicates that the Clinton site triaxial permeability tests may provide a representative value for the $\mathrm{Kv}$ of the Glasford deposits at CLU\#3. The calculated (maximum) $\mathrm{Vv}$ was $0.66 \mathrm{ft} / \mathrm{yr}$, indicating it would take an estimated minimum of 230 years for groundwater to flow through from the top of the Berry Clay Member to the top of the Mahomet aquifer (table 3).

\section{Scenario Five, Vertical Hydraulic Conductivity Equal to Value for Banner Formation Tills from Regional Groundwater Flow Model}

Using the $\mathrm{Kv}$ value of the till deposits in the Banner Formation to solve equation 3 for the $n_{e}$ of the deposits above the Upper Radnor Till Sand is not appropriate because the Banner Formation is below the Upper Radnor Till Sand (figs. 6, 17). Therefore, the $n_{e}$ of 0.021 based on the Kv from Clinton site 


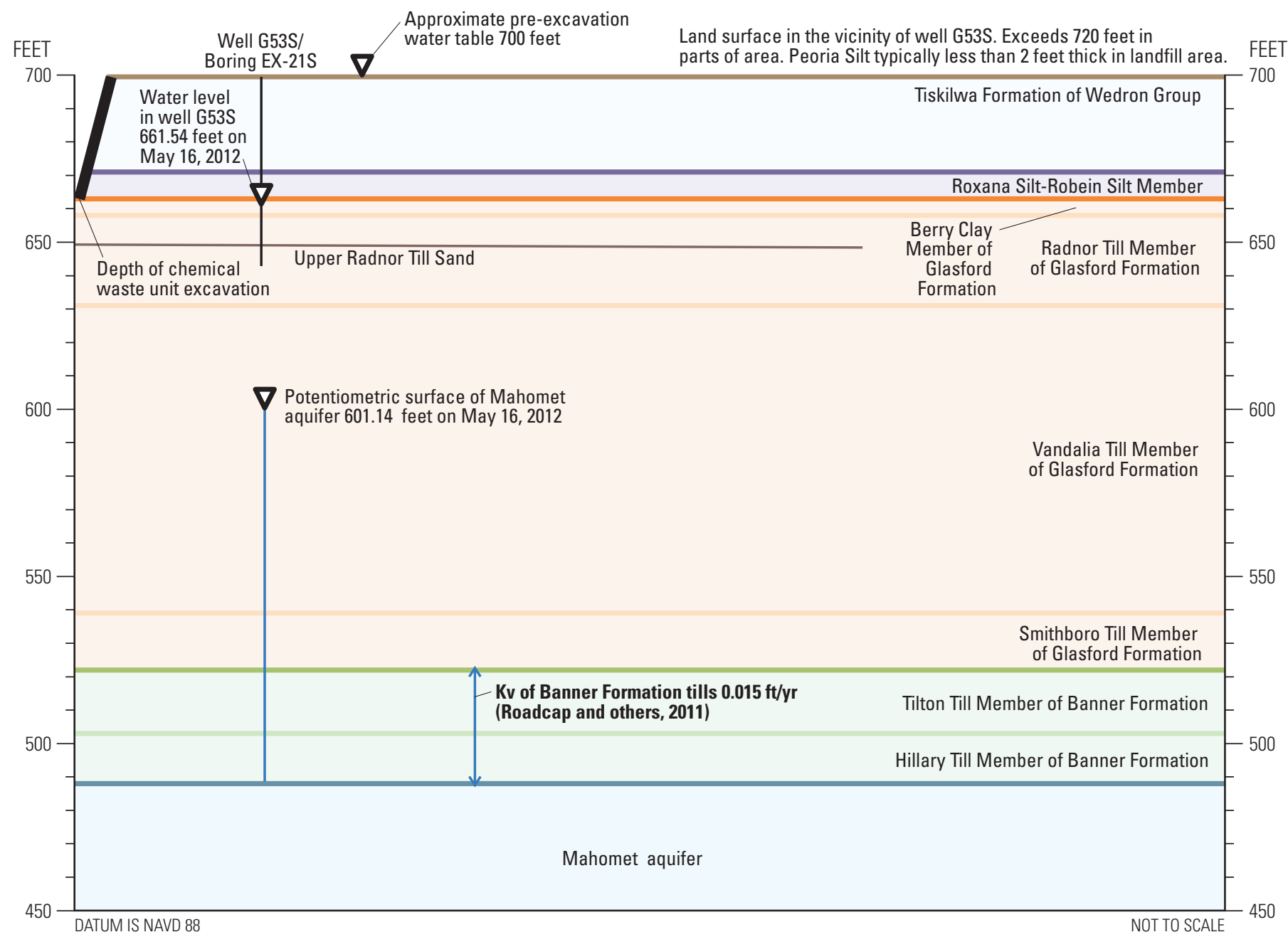

\section{EXPLANATION}

Kv $0.015 \mathrm{ft} / \mathrm{yr} \quad$ Vertical hydraulic conductivity of deposit, and value, in feet per year (ft/yr)

Figure 17. Conceptual diagram of features and data used in the solution of the Darcy velocity equation according to scenario five for the deposits at Clinton landfill unit \#3, near Clinton, Illinois.

triaxial permeability tests of the Tiskilwa Formation, Roxana Silt-Robein Silt Member, and Berry Clay Member (PDC Technical Services, Inc., 2005) was used. Again, this is the lowest $\mathrm{n}_{\mathrm{e}}$ value determined for the Clinton site, which will result in the highest calculated $\mathrm{Vv}$ and the shortest travel time. Use of the model-derived Kv for the Banner Formation tills (0.015 ft/yr; Roadcap and others, 2011) to calculate Vv from the Berry Clay Member to the top of the Mahomet aquifer results in a low $\mathrm{Vv}$ value $(0.27 \mathrm{ft} / \mathrm{yr})$ in comparison to $\mathrm{Vv}$ values in scenarios one, two, and four (table 3 ). This scenario indicates that if the $\mathrm{Kv}$ of the Banner Formation till deposits at CLU\#3 and the CWU is lower than that calculated from the triaxial permeability tests of the overlying Glasford Formation (triaxial tests were not reported for any of the Banner Formation deposits; PDC Technical Services, Inc., 2005), the $\mathrm{Vv}$ calculated from the triaxial permeability tests in scenarios one and two may underestimate the actual minimum transport time from the top of the Berry Clay Member to the top of the Mahomet aquifer. The calculated (maximum) Vv was $0.27 \mathrm{ft} /$ yr indicated that groundwater would take an estimated minimum of 580 years to flow through from the top of the Berry Clay Member to the top of the Mahomet aquifer (table 3).

\section{Summary of Hydrogeology and Recharge Interpretations from Clinton Site Data}

At the Clinton site, the Upper Radnor Till Sand, the Lower Radnor Till Sand and the Organic Soil unit have limited hydraulic interconnection with the Mahomet aquifer and have limited potential to communicate post-1952 recharge through overlying glacial till to the Mahomet aquifer, as indicated by 
several characteristics and computed times of groundwater travel.

- The presence of a low tritium detection in one of the two samples collected from the Upper Radnor Till Sand (well G53S at $0.32+/-0.10 \mathrm{TU}$ );

- The absence of detectable tritium in the other six groundwater samples and one sequential replicate sample collected from the Clinton site, including a well in the Mahomet aquifer;

- The thickness and lateral extent and continuity of lowpermeability till deposits beneath CLU\#3 (estimated at approximately 155 feet); and

- The large differences in the water levels between the Upper and Lower Radnor Till Sands, and the Organic Soil unit and the Mahomet aquifer.
The travel time for groundwater to flow from the top of the Berry Clay Member (at the bottom of the proposed CWU) to the top of the Mahomet Aquifer was estimated to be 200 years or more, using a maximum vertical groundwater velocity of less than 0.85 feet per year derived from the interpreted age of a groundwater sample from monitoring well G53S. This travel time was less than travel time estimates across the same interval that ranged from 230 to 580 years that were derived from Darcy velocity computations computed using site and literature derived hydraulic data and properties. 


\section{Regional Indications of Recharge to the Mahomet Aquifer from Previously Collected Tritium and Pesticide Data}

\author{
By Paul M. Buszka and William S. Morrow
}

This report section interprets previously collected USGS tritium and pesticide data from the confined part of the Mahomet aquifer in the Illinois River Basin (fig. 3) to evaluate the heterogeneity of recharge characteristics of the overlying glacial till through the detection of pre-1953 and post-1952 recharge. The regional tritium-based groundwater age estimates were compared with pesticide detections in samples from distal domestic wells in the USGS regional network that are about 2.5 to 40 miles from the Clinton site to identify whether very small amounts of post-1952 recharge have in places reached confined parts of the Mahomet aquifer at locations other than the Clinton site in an approximately 2,000 square mile area of the Mahomet aquifer. Very small amounts of post-1952 recharge were defined in this analysis as less than about 2.5 percent of the total recharge contributing to a groundwater sample, based on results from the two-part mixing analysis of tritium data. Previous interpretations of hydrogeologic and water-chemistry data from an approximately 3,940 square mile area of Central Illinois (figs. 1 and 4 in Roadcap and others, 2011) indicated the potential for some regional heterogeneity of recharge characteristics in the glacial till that overlies the confined part of the Mahomet aquifer (Roadcap and others, 2011; Mehnert and others, 2004). These interpretations of previously collected data, referenced as "regional results", are compared to the interpretations in the section titled "Summary of Hydrogeology and Recharge Interpretations from Clinton Site Data". Those interpretations indicated limited hydraulic interconnection through the predominantly glacial till deposits overlying the Mahomet aquifer and limited potential to communicate post-1952 recharge through overlying glacial till deposits to the Mahomet aquifer from the much smaller Clinton site.

Specific estimates of the range of travel times from the land surface to the Mahomet aquifer at the proposed CWU site were compared with regional indicators of recharge in samples collected by the USGS from 1996 to 2011 from domestic wells scattered throughout the confined part of the Mahomet aquifer in the Illinois River Basin surrounding the Clinton site, an area of approximately 60 by 25 miles or about 2,000 square miles (fig. 18A). The pre-existing domestic wells are 2.5 to about 40 miles from the CLU\#3 site and were originally selected to represent groundwater conditions in the Mahomet Buried Bedrock Valley for the USGS National Water Quality Assessment Program (Morrow, 2001 and fig. 18A). Heterogeneity in the overlying glacial deposits can result in substantial variations in the groundwater flow rates from location to location. Pesticide detections from a 1996-98 USGS regional sampling of the Mahomet aquifer at the 30 domestic wells that are 2.5 to about 40 miles from the Clinton site (table 4, at the back of this report, fig. 18B) previously have been interpreted as indicating that some modern recharge has reached the confined part of the Mahomet aquifer in the vicinity of these wells (Mehnert and others, 2004, p. 6-7). Mehnert and others (2004) also interpreted that pesticide detections in water samples from 10 of the 30 domestic wells indicated a limited amount of modern recharge contribution to an overall older, pre-1953 groundwater age in those samples.

Because of geological heterogeneity, indications of recharge and time of travel from the regional sampling results may be difficult to relate to results from the Clinton site. Assuming the domestic wells in the regional study were properly constructed and that the sampling results reflect the water quality in the Mahomet aquifer, the data indicate that heterogeneity exists in the recharge characteristics of glacial materials overlying the confined part of the Mahomet aquifer in the area shown in figures $18 A$ and $18 B$. Spatial variability in the amount of silt, clay and sand in the glacial materials above the Mahomet aquifer has been suggested as a characteristic that regionally affects recharge to the Mahomet aquifer (Roadcap and others, 2011; Panno and others, 1994). In other words, the water quality in a sample collected from a well screened in the Mahomet aquifer may be affected by the local glacial stratigraphy in the overlying materials.

Interpretation of the pesticide and tritium concentrations reported from the regional well network depends on the integrity of wells used to collect the water samples. It is possible that pesticide detections used to interpret recharge age in the regional well network could be affected by well construction and human-affected local infiltration of contaminants as well as by natural avenues of sparsely distributed vertical permeability near the well. The wells previously sampled by the USGS (table 4, fig. 18B) were existing domestic wells that were installed by water-well driller representatives of the private landowner. Construction documentation for the off-site domestic wells was limited to that recorded by the driller in the log for each well and as archived by the Illinois State Geological Survey (2014). Because of available time and documentation, the quality of the well construction was assessed by (1) selecting domestic wells constructed in 1979 or later to reflect more recent construction and documentation practices, (2) an inspection of visible characteristics at each wellhead at the time of initial well selection, pre-sampling development, and water sampling for indications of nearby pesticide storage or use and indications of potential well bore or annular transport of pesticides from the surface to the screened interval in the well and (3) a review of driller records 


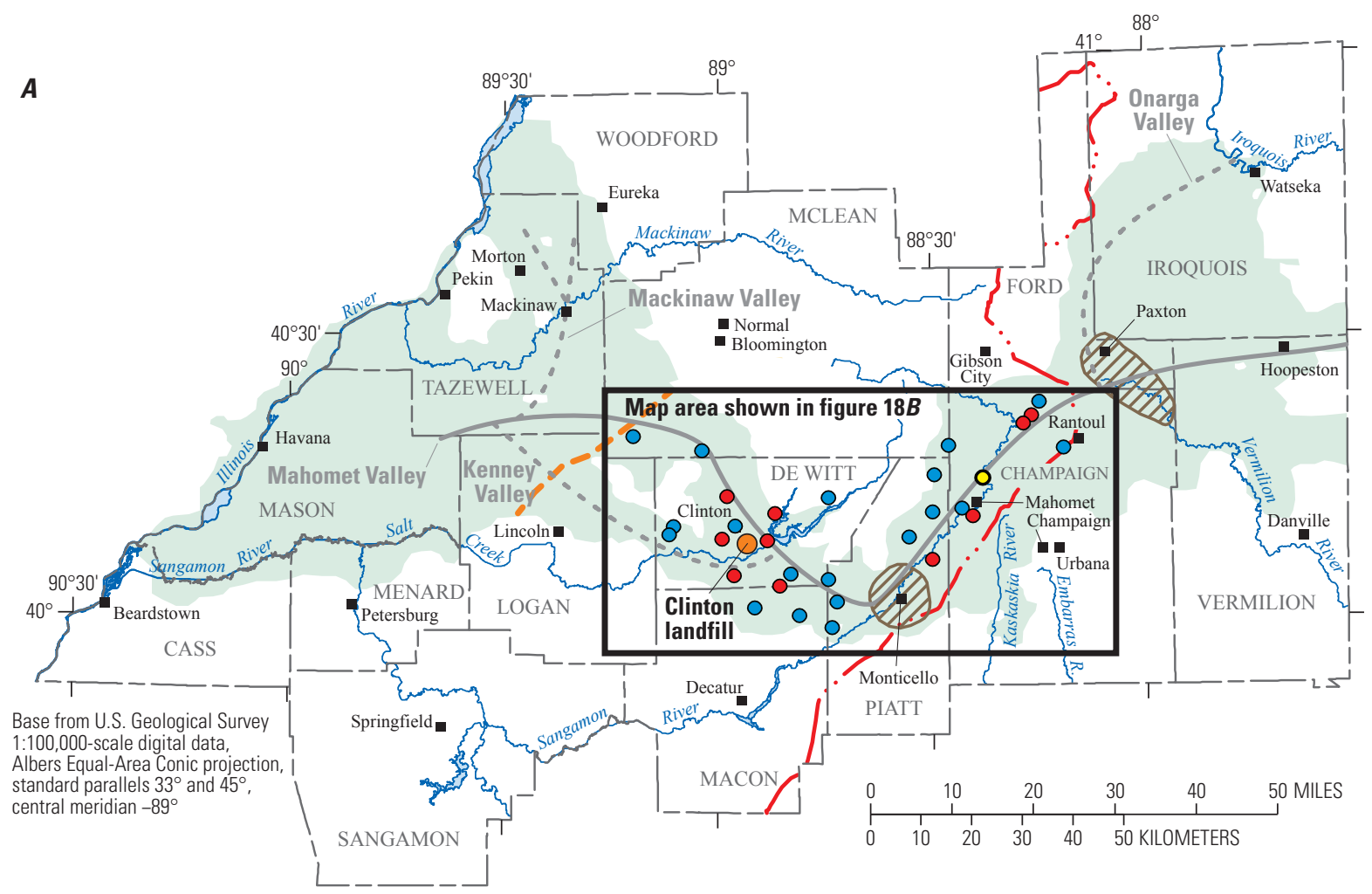

EXPLANATION

Mahomet aquifer present
$\begin{aligned} & \text { Approximate area of enhanced aquifer recharge near Paxton and Monticello } \\ & \text { Centerline of Mahomet Valley }\end{aligned}$
Centerline of tributary valley
Western boundary of Mahomet Buried Bedrock Valley in Lower Illinois River
Basin as used in Morrow (2001)
Illinois River Basin
U.S. Geological Survey Mahomet aquifer well with well identifier from table 4
Previously sampled well
Previously sampled well with detections of pesticide in water samples in 1996, 1998, 2005, or 2007
Previously sampled well with tritium detection of 5.7 tritium units (TU) in 2007

Figure 18. Locations of domestic wells in regional Mahomet aquifer network in east-central Illinois that previously were sampled by the U.S. Geological Survey for pesticide and tritium concentrations, 1996-2011. A. Sampled wells relative to the confined part of the Mahomet aquifer between the eastern boundary of the Illinois River Basin and the western boundary of the Mahomet Buried Bedrock Valley and $B$. Sampled wells in an inset area centered on the confined part of the Mahomet aquifer.

for those wells as reported to the State of Illinois (Illinois State Geological Survey, 2014). The regional wells were selected to be sampled using criteria initially described by Lapham and others (1995) and further defined by Lapham and others (1997). The regional wells were pumped to evacuate at least three well volumes of water and ensure stability of fieldmeasured water-quality properties in the produced water as described in (Koterba and others, 1995) before sampling to minimize the effect of short-term (days to months) humanaffected well-bore leakage and enhance the likelihood that the sample represented ambient groundwater quality.

Tritium and pesticide results from prior groundwater sampling have been used as regional indicators of modern (post-1952) recharge to the Mahomet aquifer in Illinois. The interpretation of tritium concentrations in groundwater from the Mahomet aquifer has been provided by Hackley and others 
$\boldsymbol{B}$

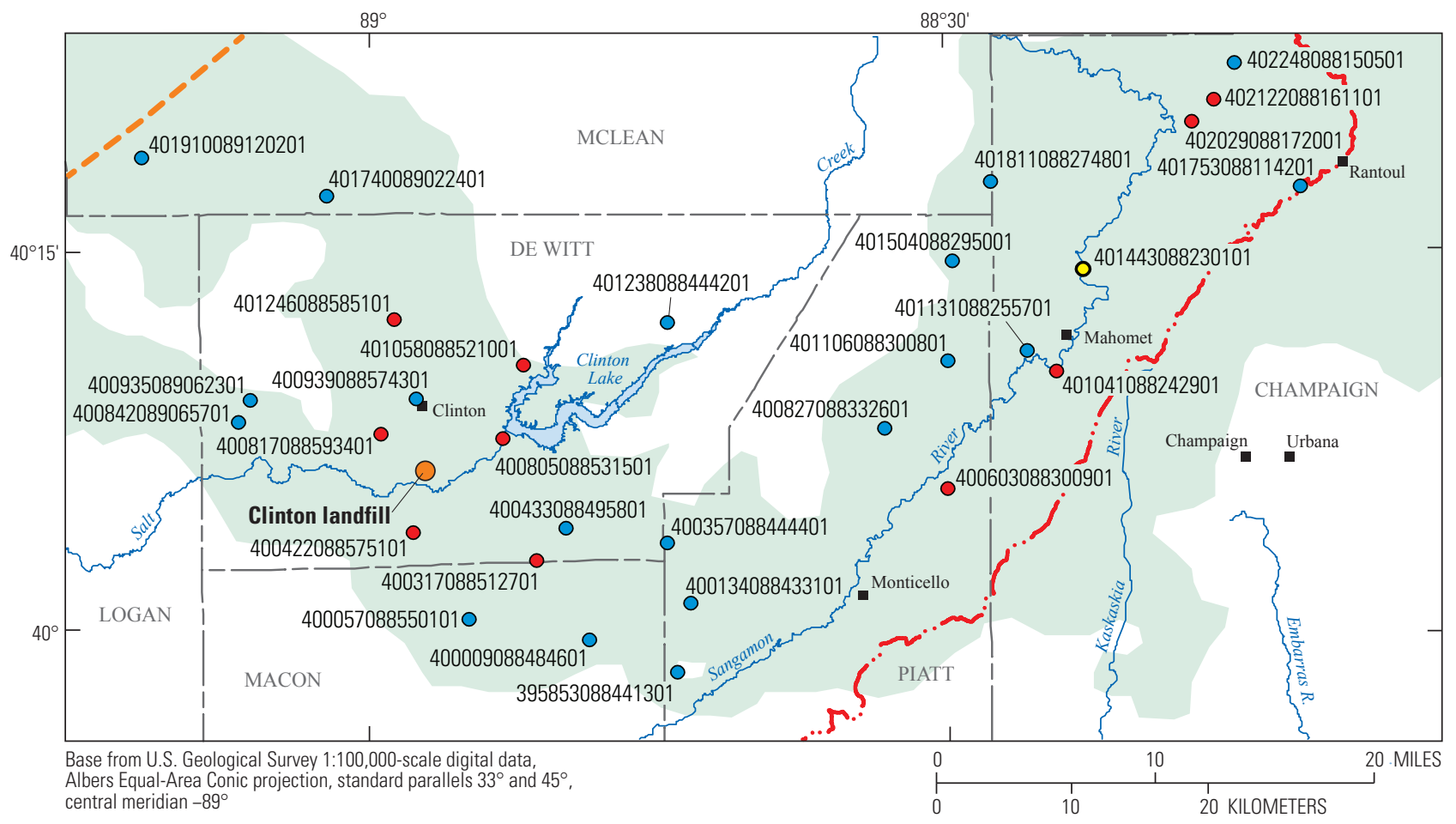

EXPLANATION

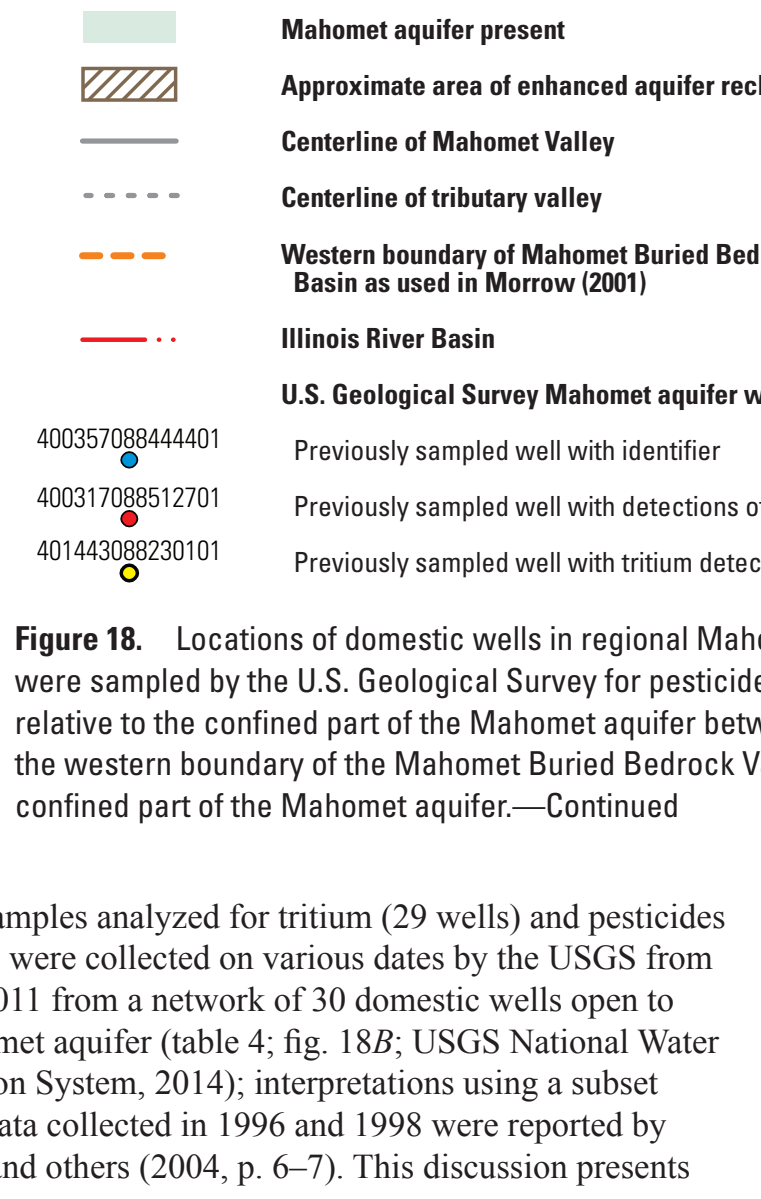

Figure 18. Locations of domestic wells in regional Mahomet aquifer network in east-central Illinois that previously were sampled by the U.S. Geological Survey for pesticide and tritium concentrations, 1996-2011. A. Sampled wells relative to the confined part of the Mahomet aquifer between the eastern boundary of the Illinois River Basin and the western boundary of the Mahomet Buried Bedrock Valley and B. Sampled wells in an inset area centered on the confined part of the Mahomet aquifer.-Continued

(2010). Samples analyzed for tritium (29 wells) and pesticides (30 wells) were collected on various dates by the USGS from 1996 to 2011 from a network of 30 domestic wells open to the Mahomet aquifer (table 4; fig. 18B; USGS National Water Information System, 2014); interpretations using a subset of those data collected in 1996 and 1998 were reported by Mehnert and others (2004, p. 6-7). This discussion presents background information about regional tritium and pesticide data and the interpretation approaches used by these authors.

\section{Regional Tritium Data}

Tritium, major ions, stable isotopes of oxygen and hydrogen and water-level data were interpreted to indicate that 
groundwater in the Mahomet aquifer in western Piatt, De Witt (where the CWU is proposed), and McLean counties is relatively more isolated from direct surficial recharge as compared with the area of enhanced recharge in central Piatt County (Panno and others, 1994; Hackley and others, 2010). Tritium was detected in groundwater in 2 of 27 samples from wells in the Mahomet aquifer (Hackley and others, 2010). The two samples with detectable tritium were from wells in the vicinity of an area of enhanced recharge in central Piatt County (Fig. 18A). Tritium was not detected in samples from the aquifer in the rest of east-central Illinois (De Witt, Macon, Champaign, McLean Counties and the rest of Piatt County) (Hackley and others, 2010). The tritium samples described in Hackley and others (2010) were collected before 2002, based on their previous sampling and reporting by Hackley (2002). The two tritium detections had concentrations of 0.62 and 0.73 tritium units (TU). These data were interpreted as indicating little to no "modern" or post-1952 recharge was present in the Mahomet aquifer outside of an enhanced recharge area in central Piatt County as proposed by Hackley and others (2010). This interpretation is consistent with the classification system of Clark and Fritz (1997); groundwater with tritium concentrations less than about 0.8 TU (as of about 1997) is "submodern" and was substantially composed of pre-1953 recharge and groundwater with tritium concentrations greater than about 0.8 TU (as of about 1997) is "modern" and contains substantial amounts of post-1952 recharge.

Groundwater-age estimates from the USGS regional data indicated largely pre-1953 recharge dates for groundwater sampled from the confined part of the Mahomet aquifer in the area shown in Figures $18 A$ and $18 B$. Tritium concentrations that were less than or equal to $0.2 \mathrm{TU}$ in USGS samples from 10 domestic wells sampled in 2007 indicated that they were substantially composed of submodern (pre-1953) recharge (table 4). A negative tritium concentration is equivalent to zero for reporting purposes; a negative value originates from tritium derived decay counts yielded from analysis of the sample that was less than the analytical background. In addition, samples collected in 1996 from two domestic wells (400827088332601 and 400817088593401 , fig. 18B) had tritium concentrations of $<0.3 \mathrm{TU}$ (table 4); indicating that they were substantially composed of submodern water. A search of the USGS National Water Information System (NWIS) database identified one domestic well sampled in 2007 (well 401443088230101 ) about 30 miles east-northeast of the Clinton area in Champaign County north of the City of Mahomet with a tritium concentration of $5.7 \mathrm{TU}$ that indicated the sample was substantially composed of modern, post- 1952 recharge (table 4, fig. 18B). Most tritium data indicate submodern water in the Mahomet aquifer outside of an enhanced recharge area in central Piatt County proposed by Hackley and others (2010) and away from the sole USGS tritium-based indication of modern recharge in Champaign County described earlier in this paragraph.
USGS water samples from 16 wells sampled from the Mahomet aquifer in 1997-98 had inconclusive tritium results relative to the submodern/modern tritium age classification. These 16 wells had water samples that were analyzed for tritium using a method with a reporting level $(<1.8 \mathrm{TU})$ that was too high to indicate whether modern, post-1952 recharge was substantially absent (table 4 ). A reporting level of $<1.8 \mathrm{TU}$ is greater than the $<0.8 \mathrm{TU}$ concentrations that would indicate submodern, pre- 1953 recharge in samples collected during 1997 and 1998 (Clark and Fritz, 1997). With $\mathrm{a}<1.8 \mathrm{TU}$ reporting level, there could be a small component of modern, post- 1952 recharge in those groundwater samples from the confined part of the Mahomet aquifer.

\section{Regional Pesticide Data}

In an effort to determine whether additional analytes beyond tritium in groundwater may be useful in identifying potential areas of recharge, the USGS compiled pesticide data from a prior 1996-2011 sampling of a network of 30 domestic wells shown in figure $18 B$ that are screened in the confined part of the Mahomet aquifer (covering approximately 2,000 square miles) in the Illinois River Basin. A search of the USGS National Water Information System (NWIS) database identified 14 water samples collected from 10 wells in the network of 30 domestic wells from 1996 to 2011 that contained detectable concentrations of one or more pesticides (table 4). Twenty of the 30 domestic wells sampled the confined part of the Mahomet aquifer by USGS from 1996 to 2011 yielded water samples that had no detectable pesticide concentrations.

All pesticide detections in the regional Mahomet aquifer groundwater samples were at sub-microgram per liter concentrations (nanograms per liter or parts per trillion), just above the detection limits for the analytical methods used. Thirteen of 22 pesticide detections were reported as estimated concentrations, indicating that the compounds were detected in the samples but a larger statistical uncertainty was associated with the concentrations reported for those analytical results (Oblinger-Childress and others, 1999; table 4). The pesticides detected included atrazine, cyanazine, diazinon, metolachlor, molinate, prometon, and trifluralin and a pesticide breakdown product, deethylatrazine. Six wells had one sample each with detections of at least one or more pesticides including atrazine, metolachlor, diazinon, prometon, cyanazine, metribuzin, and molinate that were not reproduced in a subsequent sample (6 samples with pesticide detections and 11 samples with no detections) (table 4; National Water Information System, 2014). The concentrations of the pesticides were at or near their analytical reporting levels (table 4). The highest pesticide concentration was measured in a 1996 sample from well 401058088521001, which had a molinate detection at $0.019 \mu \mathrm{g} / \mathrm{L}$.

Four wells had detections of the same pesticide in samples from successive sampling periods. Two atrazine detections in the 1998 samples were from wells 402029088172001 
$(0.002 \mu \mathrm{g} / \mathrm{L}$ estimated concentration) and 401041088242901 $(0.011 \mu \mathrm{g} / \mathrm{L}$; table 4). Diazinon was detected in the 1998 sample from well $400422088575101(0.0138 \mu \mathrm{g} / \mathrm{L})$ that had a prior detection of the same pesticide in a 1996 sample $(0.025 \mu \mathrm{g} / \mathrm{L}$ estimated concentration) (table 4$)$. One pesticide (prometon) detection in the $2007(0.007 \mu \mathrm{g} / \mathrm{L})$ samples was from well 400805088531501 with a prior detection of the same pesticide in a 2005 sample $(0.005 \mu \mathrm{g} / \mathrm{L})$ (table 4). Metolachlor was detected in a 1998 sample from well $401041088242901(0.007 \mu \mathrm{g} / \mathrm{L})$ and in a 1996 from well $400817088593401(0.004 \mu \mathrm{g} / \mathrm{L})$ and estimated concentrations of metolachlor were measured in samples collected in 1998 from three other regional wells (table 4). Deethylatrazine and trifluralin were detected at estimated values in two wells in samples collected in 1996 (table 4). Cyanazine was detected in a 1998 sample from well $401041088242901(0.013 \mu \mathrm{g} / \mathrm{L})$. The highest pesticide concentration was detected in a 1996 sample from well 401058088521001, which had a molinate detection with a concentration of $0.019 \mu \mathrm{g} / \mathrm{L}$.

Detections of pesticide compounds previously have been compared with their date of registration to indicate a contribution of modern recharge to a groundwater sample (Barbash and others, 2001). Among the pesticides detected in the domestic well network in the Mahomet aquifer are the following:

- Diazinon was registered in the United States in 1956,

- Atrazine was registered in the United States in 1958,

- Prometon was registered in the United States in 1959,

- Trifluralin was registered in the United States in 1962,

- Cyanazine was registered in the United States in 1971,

- Metolachlor was registered in the United States in 1976, and

- Molinate was registered in the United States in 1992; as referenced in U.S. Environmental Protection Agency documents (2014, 2008, 2006a, 2006b, 1996, 1995, 1984 , table 5, at the back of this report).

Conceptually, the detection of prometon in groundwater from a well, if representative of aquifer conditions and collected from a properly-constructed well, indicates that a component of the affected groundwater sample was composed of 1959 or younger recharge. Therefore, the longest possible travel time from land surface to the Mahomet aquifer of some part of the water in a sample from a well with a pesticide detection can be approximated as the difference of the year the water was sampled and the year of registration of the compound.

Maximum times of travel from land surface to the Mahomet aquifer for a small part of the water sampled from wells with pesticide detections (table 5) ranged from 4 to 46 years with minimum estimated vertical velocities from 5 to $84 \mathrm{ft} / \mathrm{yr}$. The following are examples summarized from table 5 .
- About 4 years or less for well 401058088521001 with a total depth to the top of the producing interval of 336 feet and a minimum vertical groundwater velocity of $84 \mathrm{ft} / \mathrm{yr}$ estimated from a detection of molinate in a 1996 sample at $0.019 \mu \mathrm{g} / \mathrm{L}$ (tables 4 and 5; molinate registered in 1992, U.S. Environmental Protection Agency, 2014);

- About 20 years or less for well 400817088593401 with a total depth to the top of the producing interval of 269 feet and a minimum vertical groundwater velocity of $13 \mathrm{ft} / \mathrm{yr}$ estimated from a detection of metolachlor in a 1996 sample at $0.004 \mu \mathrm{g} / \mathrm{L}$ (tables 4 and 5);

- About 22 years or less for well 402029088172001 with a total depth to the top of the producing interval of $197 \mathrm{ft}$ and a minimum vertical groundwater velocity of $9 \mathrm{ft} / \mathrm{yr}$ with a detection of metolachlor in 1998 at 0.002 $\mu \mathrm{g} / \mathrm{L}$ estimated concentration (tables 4 and 5 ; metolachlor registered in 1976, U.S. Environmental Protection Agency, 1995);

- About 22 years or less for well 400422088575101 with a total depth to the top of the producing interval of 276 feet and a minimum vertical groundwater velocity of $13 \mathrm{ft} / \mathrm{yr}$ estimated from a detection of metolachlor in a 1998 sample at $0.002 \mu \mathrm{g} / \mathrm{L}$ estimated concentration (tables 4 and 5);

- About 38 years or less for well 402122088161101 with a total depth to the top of the screen at $249 \mathrm{ft}$ and a minimum vertical groundwater velocity of $7 \mathrm{ft} / \mathrm{yr}$ with a detection of atrazine in 1996 at $0.002 \mu \mathrm{g} / \mathrm{L}$ estimated concentration (tables 4 and 5; atrazine registered in 1958, U.S. Environmental Protection Agency, 2006b); and

- About 46 years or less for well 400805088531501 with a total depth to the top of the producing interval of 242 feet and a minimum vertical groundwater velocity of $5 \mathrm{ft} / \mathrm{yr}$ estimated from a detection of prometon in a 2005 sample at $0.005 \mu \mathrm{g} / \mathrm{L}$ (tables 4 and 5; prometon registered in 1959, U.S. Environmental Protection Agency, 2008).

For the wells with pesticide detections, the screened interval in the Mahomet aquifer is overlain by 166 to 291 feet of till-dominated glacial material. The relative lack of tritium in these samples indicates that the amounts of post-1956 to post1992 recharge contributing to the 10 domestic wells were a very small part of the overall older groundwater sampled from the wells. A very small amount of post-1952 recharge was previously defined in the section of this report titled "Two-Part Mixing Model Evaluation of Tritium-Based Groundwater Age Estimates at the Clinton Site" as less than about 2.5 percent of the total recharge contributing to a groundwater sample. For example, if the pesticide contamination migrated vertically 
through natural features in the tills proximal to the affected wells and the maximum transit times for the pesticides can be determined from pesticide registration dates, the pesticidebased ages of groundwater from wells 400817088593401 and 400317088512701 were younger than what would be predicted from the groundwater age that was computed using tritium data (table 5). For example, well 400817088593401 has a total depth below land surface to the top of the well screen of 269 feet below land surface and a maximum travel time of 20 years for the pesticide metolachlor that was registered in 1976 and detected in 1996 at a concentration of 0.004 $\mu \mathrm{g} / \mathrm{L}$ (U.S. Environmental Protection Agency, 1995; data in tables 4 and 5). In contrast, a tritium-based age date from the same sampling event for this well indicated that the sample was composed predominantly of pre-1953 age recharge. The pesticide detections in samples from wells 400817088593401 and 400317088512701 indicate the presence of very small amounts of modern, post-1952 age recharge in the overall older, pre-1953 age groundwater indicated by tritium concentrations in samples from those wells.

The detection of the pesticide molinate in a 1996 sample from well 401058088521001 indicated the fastest maximum time of travel of recharge to a well in the confined part of the Mahomet aquifer. Well 401058088521001 has a total depth below land surface to the top of the well screen of 336 feet below land surface and a maximum travel time of 4 years for the pesticide molinate that was registered in 1992 and detected in 1996 at a concentration of $0.019 \mu \mathrm{g} / \mathrm{L}$ (U.S. Environmental Protection Agency, 2014; data in tables 4 and 5). This results in a computed vertical velocity through the overlying 282 feet of till-dominated glacial material to the top of the well screen at $336 \mathrm{feet}$ of no less than approximately $84 \mathrm{ft} / \mathrm{yr}$; nearly 100 times higher than the maximum vertical groundwater velocity estimated for glacial till at the Clinton site using the tritium data $(0.85 \mathrm{ft} / \mathrm{yr})$. As four years is the maximum transit time available, the vertical velocity computed using this transit time is a minimum vertical groundwater velocity. Consequently, if molinate was not used in the vicinity of this well until 1994, the maximum travel time would be reduced to two years and the vertical velocity would be twice as high or approximately $170 \mathrm{ft} / \mathrm{yr}$. Minimum vertical velocities computed from the other 9 wells with pesticide detections ranged from 5 to $13 \mathrm{ft} / \mathrm{yr}$ (table 5). The flow processes by which molinate and the other pesticides migrated vertically through more than 166 to 291 feet of till-dominated glacial material could not be distinguished using the available data from processes related to well integrity or to characteristics of the local hydrogeology. Potential explanations include: (1) infiltration through man-made avenues in or along the well, (2) flow of very small amounts of post-1956 to post-1992 recharge through sparsely distributed natural permeable aspects of the glacial till and diluted by mixing with older groundwater, or (3) a combination of both processes.

The potential for well-integrity related migration of one or more pesticides along an annular space or through the well bore could not be ruled out. For example, back-siphoning down the well through the plumbing systems associated with pesticide and fertilizer use has been described as a potential cause of the presence of contaminants in water from production wells in other agricultural areas outside Illinois (Kross and others, 1992; Sievers and Fulhage, 1992). The off-site, regional pesticide data were collected by prior USGS efforts in 1996 through 2011 from a series of domestic wells drilled after 1978 and as described earlier, details of their construction were limited. These concerns are described in the emphasis given to well construction and well construction documentation in technical literature on wells used to sample water quality (Lapham and others, 1997; Driscoll, 1986; Yeskis and Zavala, 2002). As examples, six of the seven wells used in the Clinton site study were groundwater monitoring wells drilled, constructed and documented to conform with protocols that better assure the integrity of samples provided by those wells.

\section{Indications of Regional Heterogeneity in Recharge to the Confined Part of the Mahomet Aquifer}

Assuming the domestic wells in the regional study were properly constructed and that the sampling results reflect the water quality in the Mahomet aquifer, these results indicate the glacial drift stratigraphy above the confined part of the Mahomet aquifer exhibits substantial heterogeneity and that parts of the aquifer with the pesticide detections can be susceptible to contaminant sources at the land surface. Ten of the 30 domestic wells in the regional study network were associated with pesticide detections in groundwater from the confined part of the Mahomet aquifer (table 4). Because the confined part of the Mahomet aquifer covers about 2,000 square miles of glacial terrain, such a conclusion is not surprising. Some heterogeneity in the vertical distribution of glacial deposits over the Mahomet aquifer previously has been described (Roadcap and others, 2011). The pesticide-based groundwater-age results, when used with tritium data, indicate the potential value of sub-microgram-per-liter level concentrations of land-use derived indicators of modern recharge, such as pesticides in agricultural areas, to indicate presence of very small amounts of modern, post-1952 age recharge in overall older, pre-1953 age groundwater.

The Clinton site groundwater-age dates derived from tritium results (table 1) do not conform with the rapid recharge rates indicated at the 10 domestic wells in the regional network associated with pesticide detections (table 5, fig. 18B). In De Witt County where the Clinton site is located, 6 of 11 domestic wells in the regional network were associated with pesticide detections (table 5, fig. 18B). In contrast, permeable deposits within the Lower Radnor Till Sand and Organic Soil unit and at the one well in the Mahomet aquifer contain pre-1953 age recharge that indicate low rates of vertical groundwater flow at the Clinton site. The low rates of vertical groundwater flow and the vertical head differences between permeable deposits within the Lower Radnor Till 
Sand and Organic Soil units and the underlying Mahomet aquifer at the Clinton site further indicates a lack of the types of "enhanced permeability" hydrogeologic features such as vertically interconnected sands that have been proposed by Roadcap and others (2011) to explain recharge to the confined part of the Mahomet aquifer.

\section{Data Limitations}

A more precise assessment of the time of travel to the Mahomet aquifer from the Clinton site-including the CLU\#3-is limited by the available $\mathrm{n}_{\mathrm{e}}$ and $\mathrm{Kv}$ values and the small number of borings with detailed geologic descriptions of the deposits between the Organic Soil unit and the Mahomet aquifer. The $n_{e}$ values used to represent till units for estimates of vertical velocity and time of travel were derived from a single tritium analysis of one groundwater sample. The lack of precision in $\mathrm{n}_{\mathrm{e}}$ and $\mathrm{Kv}$ values can affect travel time estimates.

Estimates of vertical travel time through the glacial till at the Clinton site in this report were based on single groundwater-level measurements at observation wells. Analysis of previously collected groundwater-level data at these wells could be used to represent the likely variability of vertical groundwater velocity in response to seasonal and annual changes in groundwater levels and how that variability affects vertical velocity and travel time estimates.

The estimates of vertical groundwater flow velocity and travel time included assumptions that geologic deposits below the Organic Soil unit had the same permeability and $\mathrm{n}_{\mathrm{e}}$ characteristics as those above the unit. Hydrogeologic data from wells and borings were less available at CLU\#3 for deposits beneath the Organic Soil unit to the Mahomet aquifer than from land surface to the Organic Soil unit. Additional Kv and $n_{e}$ data from the geologic deposits below the Organic Soil unit would improve the understanding of the precision and variability of $\mathrm{Vv}$ and travel time estimates calculated from the Darcy velocity equation.

This report also identified several questions that could not be answered by available data related to the routes by which pesticides detected in wells sampled by the USGS infiltrated through the glacial till or along well-related connections to reach parts of the Mahomet aquifer that are distant from the Clinton site. Specifically, additional hydrogeologic, well condition, and land-use data are needed to evaluate the presence or absence of local conditions that would contribute to the migration of pesticide and land-use related compounds to the Mahomet aquifer as reported for the 10 wells in the regional network. This validation of processes responsible for detections of anthropogenic compounds is particularly needed at sites where pesticides and land-use related anthropogenic contaminants have been detected. Data that could assist with this validation include but are not limited to the following:

- Re-evaluation of the USGS sampled domestic wells in the Mahomet aquifer related to the following:
- Well-construction documentation,

- Sampling-related observations of well condition, land use, and pesticide storage and use, and

- Field and laboratory quality assurance data compiled with the pesticide detections;

- A regional evaluation of field notes and literature on the history of the use and storage of pesticides in the area over the confined part of the Mahomet aquifer,

- Collection of additional hydrogeologic data through drilling, sampling, and hydraulic testing to identify the presence and distribution of natural avenues of vertical permeability described for glacial tills in other regions (McKay and others, 1993; Abichou and others, 2002; Herzog and Griffin, 1990; Herzog and Morse, 1986; Ecology and Environment, Inc., 1990), such as the following:

- Interconnected sand lenses,

- Open or infilled fractures,

- Weathered zones, or

- Former root paths or burrows, and

- Installation and sampling of observation wells at sites over the Mahomet aquifer that could be paired with existing wells with repeat detections of pesticides and land-use related contaminants; these are the sites where data most strongly indicate the potential for vertical flow through the glacial till.

For example, Herzog and Morse (1986) and Haefner (2000) described how testing in till deposits improved evaluation of vertical hydraulic conductivity in glacial tills. Incorporating pesticide use estimates derived from county and regional surveys (Stone, 2013) could assist with this evaluation by indicating where certain pesticides were more likely to have been used.

\section{Summary and Conclusions}

The U.S. Geological Survey used interpretations of hydrogeologic conditions and tritium-based groundwater age estimates to assess the travel time of groundwater at a landfill site near Clinton, Illinois (the "Clinton site") where a chemical waste unit (CWU) was proposed to be within the Clinton landfill unit \#3 (CLU\#3). The glacial deposits underlying a proposed chemical waste unit (CWU) within Clinton landfill unit \#3 (CLU\#3) consist predominantly of low-permeability silt-and-clay rich till interspersed with thin (typically less than 2 feet in thickness) layers of more permeable deposits, including the Upper and Lower Radnor Till Sands and the Organic Soil unit. These glacial deposits are about 170 feet thick and 
overlie the Mahomet Sand Member of the Banner Formation. The Mahomet aquifer is composed of the Mahomet Sand Member and is used for water supply in much of east-central Illinois.

At the Clinton site, the Upper Radnor Till Sand, the Lower Radnor Till Sand and the Organic Soil unit have limited hydraulic interconnection with the Mahomet aquifer, as indicated by the following characteristics:

- The presence of a low tritium detection in one of the two samples collected from the Upper Radnor Till Sand (well G53S at $0.32 \pm 0.10 \mathrm{TU}$ );

- The absence of detectable tritium in the other six groundwater samples and one sequential replicate sample collected from the site, including from a well in the Mahomet aquifer;

- The thickness and lateral extent and continuity of lowpermeability till deposits beneath CLU\#3 (estimated at approximately 155 feet); and

- The large differences in the water levels between the Upper and Lower Radnor Till Sands, and the Organic Soil unit and the Mahomet aquifer.

Tritium concentrations were analyzed in water samples from six monitoring wells and one production well sampled by this study in the vicinity of the CLU\#3 at the Clinton site. The tritium-based age estimates were computed with a simplifying, piston-flow assumption: that groundwater moves in discrete packets to the sampled interval by advection, without hydrodynamic dispersion or mixing. Tritium concentrations indicate a recharge age of at least 59 years (pre-1953 recharge) for water sampled from deposits below the upper part of the Radnor Till Member at the CLU\#3, with older water indicated at progressively greater depth in the tills. The sampling results from well G53S indicate that nearly all groundwater in that well entered the ground surface as recharge before 1953. Well G53S is open to a sand deposit in the upper part of the Radnor Till Member that is at an elevation of 650 feet and a depth of about 50 feet below ground surface.

Tritium was detected at a trace concentration in a sample from a second monitoring well $(\mathrm{G} 07 \mathrm{~S} ; 0.11 \pm 0.09$ tritium units) open to the sand unit of the Upper Radnor Till Sand and possibly the Lower Radnor Till Sand. There was an absence of tritium in samples from two monitoring wells (EX-4 and EX-6) open to a sand deposit in the Lower Radnor Till Sand, from two monitoring wells (G06D and G07D) open to the Organic Soil unit, and from a production well (W-10) screened in the middle of the Mahomet aquifer. The Lower Radnor Till Sand and the Organic Soil unit are within approximately 20 feet of the base of the Upper Radnor Till Sand, whereas the Mahomet aquifer is approximately 160 feet below the base of the Upper Radnor Till Sand. The trace concentration of tritium in the sample from the second well screened in the Upper Radnor Till Sand (G07S), and the absence of tritium in the Lower Radnor Till Sand and the Organic Soil unit (EX-4, EX-6,
G06D, G07D) and the Mahomet aquifer (W-10) indicated recharge ages of at least 59 years or more (pre-1953 recharge) in these units in the vicinity of the CLU\#3. The lack of tritium in five of the six groundwater samples collected from the shallow permeable units beneath CLU\#3 site and the two samples from the one Mahomet aquifer well indicates an absence of post-1952 recharge and that groundwater-flow paths that could contribute post-1952 recharge to the lower part of the Radnor Till Member, the Organic Soil unit, or the Mahomet aquifer at the CLU\#3 are not indicated by these data.

Hypothetical two-part mixtures of tritium-dead, pre-1953 recharge water and decay-corrected tritium concentrations in post-1952 recharge were computed and compared with tritium analyses in groundwater sampled from monitoring wells at the CLU\#3 site to evaluate whether tritium concentrations in groundwater could be represented by mixtures involving some post-1952 recharge. Results from the hypothetical two-part mixtures indicate that groundwater from monitoring well (G53S) was predominantly composed of pre-1953 recharge and that if present, younger, post-1955 recharge, contributed less than 5 percent to that sample.

A maximum vertical groundwater velocity from land surface to the Upper Radnor Till Sand of less than 0.85 feet per year was derived from the interpreted age of groundwater from monitoring well G53S. The tritium result and associated vertical groundwater velocity indicate an estimated travel time of a minimum of 200 years or more for recharge to flow through the 170 feet of glacial deposits from the top of the Berry Clay Member (at the base of the proposed CWU) to the top of the Mahomet Aquifer.

The piston-flow based age of recharge determined from the tritium concentration in the groundwater sample from monitoring well G53S yielded an estimated maximum vertical velocity from the land surface to the upper part of the Radnor Till Member of 0.85 feet per year or less. This velocity, if assumed to apply to the remaining glacial till deposits above the Mahomet aquifer, indicates that recharge flows the 170 feet of glacial deposits between the base of the proposed chemical waste unit and the top of the Mahomet aquifer in a minimum of 200 years or longer. Analysis of hydraulic data from the site, constrained by a tritium-age based maximum groundwater velocity estimate, computed minimum estimates of effective porosity that range from about 0.021 to 0.024 for the predominantly till deposits above the Mahomet aquifer. Solution of the Darcy velocity equation using these effective porosity values, water-level data, and vertical hydraulic conductivity data from triaxial permeability tests of samples collected at the CLU\#3 site indicated maximum vertical groundwater velocities from the Berry Clay Member to the top of the Mahomet aquifer of 0.41 or 0.61 feet per year, depending on the site-specific values used in the equation. These velocities indicate an estimated travel time for recharge to flow from the top of the Berry Clay Member (at the bottom of the CWU) to the top of the Mahomet Aquifer to be a minimum of 260 or 370 years, depending on which velocity value is used. A more 
precise assessment of the time of travel of groundwater from land surface to the Mahomet aquifer at the Clinton site, including CLU\#3, is limited by the available effective porosity and vertical permeability values and the small number of borings with detailed geologic descriptions of the deposits between the Organic Soil unit and the Mahomet aquifer.

The Darcy velocity equation also was solved to quantify travel times using vertical hydraulic conductivity data from a previously published regional groundwater flow model. Plausible travel times estimated using the previously published, regional-model derived vertical hydraulic conductivity values ranged from 230 to 580 years; these travel time estimates were either comparable to or of longer duration than those calculated using Clinton-site tritium data (200 years or longer).

Tritium data from 1996 to 2011 USGS regional sampling of the Mahomet aquifer of groundwater from domestic wells in the confined part of the Mahomet aquifer, which are 2.5 to about 40 miles from the Clinton site, were compared with site-specific data from a production well at the Clinton site. Groundwater-age estimates indicated largely pre-1953 recharge dates for 30 USGS-sampled domestic wells and other prior regional sampling of groundwater from the Mahomet aquifer; tritium was detected in concentrations indicating largely post-1952 recharge in only one well, a USGS-sampled domestic well about 30 miles from the Clinton site vicinity. These results agreed with the pre-1953 recharge age estimated for a groundwater sample and a sequential replicate sample from a production well in the confined part of the Mahomet aquifer beneath the Clinton site.

The regional tritium-based groundwater age estimates also were compared with the pesticide detections in samples from distal domestic wells that are about 2.5 to 40 miles from the Clinton site to identify whether very small amounts of post-1952 recharge have in places reached the confined part of the Mahomet aquifer at locations other than the Clinton site in an approximately 2,000 square mile area of the Mahomet aquifer. A very small amount of post-1952 recharge was previously defined in the section of this report titled "Two-Part Mixing Model Evaluation of Tritium-Based Groundwater Age Estimates at the Clinton Site" as less than about 2.5 percent of the total recharge contributing to a groundwater sample. Groundwater-age estimates were computed for 10 domestic wells screened in the Mahomet aquifer that were 2.5 to about 40 miles from the CLU\#3 site and that had pesticide compounds detected. Groundwater-age estimates based on 22 detections of pesticides or a pesticide degradation product (13 of these detections were estimated values), including atrazine, deethylatrazine, cyanazine, diazinon, metolachlor, molinate, prometon, and trifluralin in water from 10 domestic wells in the regional network indicate that very small amounts of post-1956 to post-1992 recharge can reach the confined part of the Mahomet aquifer in other parts of central Illinois. The relative lack of tritium in these samples indicate that the amounts of post- 1956 to post-1992 recharge contributing to the 10 domestic wells were a very small part of the overall older groundwater sampled from the wells.
The flow process by which very small amounts of pesticide-bearing groundwater reached the screened interval in domestic wells in the confined part of the Mahomet aquifer through 166 to 291 feet of till dominated glacial material (in the case of the molinate detection in well 401058088521001 , the total depth to the top of the well screen was 336 feet) could not be distinguished between wellintegrity related and natural hydrogeologic features. Potential explanations include: (1) infiltration through man-made avenues through or along the well, (2) flow of very small amounts of post-1956 to post-1992 recharge through sparsely distributed natural permeable aspects of the glacial till and diluted by mixing with older groundwater, or (3) a combination of both processes. This study identified no observations or data that indicated the presence of these vertical permeable features in glacial till below the Upper Radnor Till Sand at the Clinton site. A detection of tritium in one domestic well and the detections of pesticides in samples from 10 other domestic wells indicate that characteristics that favor transport of recharge and potential contaminants from land surface to the Mahomet aquifer were present in about 33 percent of the wells in the 30-well regional network.

Presuming the off-site domestic wells sampled by the USGS in 1996-2011 in the regional study are adequately sealed and produce groundwater that is representative of aquifer conditions, the regional tritium and pesticide results indicate the following:

- The glacial stratigraphy above the Mahomet aquifer exhibits substantial heterogeneity,

- That parts of the Mahomet aquifer with the pesticide detections can be susceptible to contaminant sources at the land surface, and

- That a potential exists for possible contaminants from land surface to be transported through the glacial drift deposits that confine the Mahomet aquifer in other parts of central Illinois at faster rates than those computed for recharge at the Clinton site, including CLU\#3.

The regional pesticide and tritium results from the domestic wells indicate the potential value of submicrogramper-liter level concentrations of land-use derived indicators of modern recharge to indicate the presence of very small amounts of modern, post-1952 age recharge in overall older, pre-1953 age groundwater.

The conclusions of this investigation are based on assumptions and sources of uncertainty in the analyses presented in this report, including hydrogeologic characteristics (substantial continuity of sand deposits, continuity of till deposits, uniform groundwater velocity, uniform permeability, and uniform effective porosity, based on a tritium determination) and conceptualization of vertical flow (piston flow, which is supported by analysis of hypothetical two-part mixing models, and predominantly downward flow). Applications of these 
assumptions are explained with the appropriate analysis in the body of the report.

\section{References Cited}

Abichou, T., Benson, C., Friend, M., and Wang, X., 2002, Hydraulic conductivity of a fractured aquitard: in Sara, M.N. and Everett, L.G., eds., Evaluation and Remediation of Low Permeability and Dual Porosity Environments, , ASTM Special Technical Publication No. 1415, American Society for Testing and Materials, West Conshohocken, Penn, p. 25-27.

Bradbury, K.R., and Muldoon, M.A., 1990, Hydraulic Conductivity Determinations in Unlithified Glacial and Fluvial Materials, in Nielson, D.M. and Johnson, A.I., eds. Ground Water and Vadose Zone Monitoring, American Society for Testing and Materials, West Conshohocken, Penn., p. $138-151$.

Barbash, J.E., Thelin, G.P., Kolpin, D.W. and R.J. Gilliom, 2001, Major herbicides in ground water: Journal of Environmental Quality, v. 30, no. 3, p. 831-845.

Clark, I.D., and Fritz, P., 1997, Environmental isotopes in hydrogeology: New York, Lewis Publishers, 311 p.

Cooper Jr, H.H., Bredehoeft, J.D., and Papadopulos, I.S., 1967, Response of a finite-diameter well to an instantaneous charge of water: Water Resources Research, v. 3, no. 1, p. 263-269.

Domenico, P.A. and Schwartz, F.W., 1990, Physical and chemical hydrogeology, 2nd edition: Wiley, New York, 824 p.

Ecology and Environment, Inc., 1990, Special study report of U.S. Scrap: Prepared for the U.S. Environmental Protection Agency, Chicago, Ill., 253 p.

Gibb, J.P., Barcelona, M.J., Ritchey, J.D., and LeFaivre, M.H., 1984, Effective Porosity of Geologic Materials: First Annual Report: Illinois State Water Survey Division SWS Contract Report 351, 40 p., accessed February 4, 2014, at http://www.isws.illinois.edu/pubdoc/CR/ISWSCR-351.pdf.

Grosse, A.V., Johnston, W.M., and Libby, W.F., 1951, Tritium in nature: Science, v. 113, p. 1-2.

Hackley, K.C., Panno, S.V., and Anderson, T.F., 2010, Chemical and isotopic indicators of groundwater evolution in the basal sands of a buried bedrock valley in the midwestern United States: implications for recharge, rock-water interactions, and mixing: Geological Society of America Bulletin, v. 122 , no. $7 / 8$, p. $1047-1066$.
Hackley, K.C., 2002, A Chemical and Isotopic Investigation of the Groundwater in the Mahomet Bedrock Valley Aquifer: Age, Recharge and Geochemical Evolution of the Groundwater: University of Illinois Urbana-Champaign, Ph.D. thesis, $152 \mathrm{p}$.

Haefner, R.J., 2000, Characterization methods for fractured glacial tills: The Ohio Journal of Science. V. 100, no. 3-4 (June-September, 2000), 73-87; accessed February 26, 2014, at http://hdl.handle.net/1811/23858.

Harper, B.; Luukinen, B.; Gervais, J. A.; Buhl, K.; Stone, D., 2009. Diazinon Technical Fact Sheet; National Pesticide Information Center, Oregon State University Extension Services. [Also available at http://npic.orst.edu/factsheets/ diazinontech.pdf.]

Hinkle, S.R., Shapiro, S.D., Plummer, L.N., Busenberg, Eurybiades, Widman, P.K., Casile, G.C., and Wayland, J.E., 2010, Estimates of tracer-based piston-flow ages of groundwater from selected sites - National Water-Quality Assessment Program, 1992-2005: U.S. Geological Survey Scientific Investigations Report 2010-5229, 90 p.

Herzog, B.L., and Griffin, R.A., 1990, Investigation of failure mechanisms and migration of industrial chemicals at Wilsonville, Illinois: U.S. Environmental Protection Agency Environmental Research Brief, EPA/600/M-89/033, 8 p.

Herzog, B.L. and Morse, W.J., 1986, Hydraulic conductivity at a hazardous waste disposal site: Comparison of laboratory and field determined values: Waste Management and Research, v. 4, p. 177-187.

Illinois State Geological Survey, 2014, Illinois Water Well (ILWATER) Interactive Map: accessed February 3, 2015, at https://www.isgs.illinois.edu/ilwater.

International Atomic Energy Agency, 2006, Use of chlorofluorocarbons in hydrology-A guidebook: Vienna, Austria, $278 \mathrm{p}$.

International Atomic Energy Agency, 2013, Water Isotope System for Data Analysis, Visualization, and Electronic Retrieval (WISER): Vienna, Austria, Accessed February 20, 2013, at http://www-naweb.iaea.org/napc/ih/IHS resources_isohis.html.

Kauffman, S., and Libby, W.S., 1954, The natural distribution of tritium: Physical Review, v. 93, no. 6, p. 1337-1344.

Kempton, J.P., Johnson, W.H., Heigold, P.C., and Cartwright, K., 1991, Mahomet bedrock valley in east-central Illinois; topography, glacial drift stratigraphy, and hydrogeology, in Melhorn, W.N., and Kempton, J.P., eds., Geology and Hydrogeology of the Teays-Mahomet Bedrock Valley System. Boulder, Colo., Geological Society of America Special Paper 258: p. 91-124. 
Koterba, M.T., Wilde, F.D., and Lapham, W.W., 1995 , Ground-water data-collection protocols and procedures for the National Water-Quality Assessment Program: Collection and documentation of water-quality samples and related data: U.S. Geological Survey Open-File Report 95-399, $113 \mathrm{p}$.

Kross, B.C., Selim, M.I., Hallberg, G.R., Bruner, D.R. and Cherryholmes, Keith, 1992, Pesticide contamination of private well water, a growing rural health concern: Environment International, v. 18, no. 3, p. 231-241.

Lapham, W.W., Wilde, F.D., Koterba, M.T., 1995, Groundwater data-collection protocols and procedures for the National Water-Quality Assessment Program-Selection, installation, and documentation of wells, and collection of related data: U.S. Geological Survey Open-File Report 95-398, $71 \mathrm{p}$.

Lapham, W.W., Wilde, F.D., Koterba, M.T., 1997, Guidelines and standard procedures for studies of ground-water quality: Selection and installation of wells, and supporting documentation: U.S. Geological Survey Water-Resources Investigations Report 96-4233, 110 p.

Lucas, L.L., and Unterweger, M.P., 2000, Comprehensive review and critical evaluation of the half-life of tritium: Journal of Research of the National Institute of Standards and Technology, v. 105, no. 4, p. 541-549.

McCurdy, D.E., Garbarino, J.R., and Mullin, A.H., 2008, Interpreting and reporting radiological water- quality data: U.S. Geological Survey Techniques and Methods, book 5, chap. B6, 33 p.

McKay, L.D., Cherry, J.A., and Gillham, R.W., 1993, Field experiments in a fractured clay till 1. hydraulic conductivity and fracture aperture: Water Resources Research, v. 25, no. 4, p. 1149-1162

Mehnert, E., Hackley, K.C., Larson, T.H., Panno, S.V., Pugin, A., Wehrman, H.A., Holm, T.R., Roadcap, G.S., Wilson, S.D., and Warner, K.L., 2004, The Mahomet aquifer: Recent advances in our knowledge: Illinois State Geological Survey Open File Series 2004-16, 19 p.

Morrow, W.S., 2001, Uranium and radon in ground water in the lower Illinois River Basin: U.S. Geological Survey Water-Resources Investigations Report 2001-4056, 29 p.

Oblinger-Childress, C.J., Foreman, W.T., Connor, B.F., and Maloney, T.J., 1999, New reporting procedures based on long-term method detection levels and some considerations for interpretations of water-quality data provided by the U.S. Geological Survey National Water Quality Laboratory: U.S. Geological Survey Open-File Report 99-133, 19 p.
Panno, S.V., Hackley, K.C., Cartwright, K., and Liu, C.L., 1994, Hydrochemistry of the Mahomet bedrock valley aquifer, east-central Illinois: Indicators of recharge and groundwater flow: Ground Water, v. 32, no. 4, p. 591-604

Payne, B.R., 1972, Isotope hydrology: Advanced Hydroscience, v. 8, p. 95-138.

PDC Technical Services, Inc., 2005, Application for permit to develop a non-hazardous landfill, Clinton landfill \#3, De Witt County, Illinois, 812.314 Description of Hydrogeology, PDC Project No. 91-0118, February 2005: Prepared for the U.S. Environmental Protection Agency, Chicago, IL, 520 p., accessed April 19, 2015, at http://www.epa.gov/Region5/ waste/clintonlandfill/PDFClintonLFChemicalWaste USEPAApplication/Application/VolumeII/cl_018.pdf.

PDC Technical Services, Inc., 2006, Application for permit to develop a non-hazardous landfill, Clinton landfill \#3, De Witt County, Illinois: 812.317 Groundwater Monitoring Plan: PDC Project No. 91-0118, June 2006: Prepared for the U.S. Environmental Protection Agency, Chicago, IL, 210 p., accessed April 19, 2015, at http://www.epa.gov/ Region5/waste/clintonlandfill/PDFClintonLFChemicalWaste_USEPAApplication/Application/VolumeIV/cl_031. pdf.

Plummer, L.N., Böhlke, J.K., and Busenberg, Eurybiades, 2003, Approaches for ground-water dating, in Lindsey, B.D., Phillips, S.W., Donnelly, C.A., Speiran, G.K., Plummer, L.N., Böhlke, J.K., Focazio, M.J., Burton, W.C., and Busenberg, Eurybiades, 2003, Residence times and nitrate transport in ground water discharging to streams in the Chesapeake Bay watershed: U.S. Geological Survey WaterResources Investigations Report 03-4035, p. 12-24.

Plummer, L.N., Michel, R.L., Thurman, E.M., and Glynn, P.D., 1993, Environmental tracers for age- dating young groundwater, in Alley, W.M., Regional Ground-Water Quality: New York, Van Nostrand Reinhold, p. 255-294.

Puls, R.W., and Barcelona, M.J., 1996, Low-flow (minimal drawdown) ground-water sampling procedures: U.S. Environmental Protection Agency Office of Research and Development, EPA/540/S-95/504, 12 p.

Roadcap, G.S., Knapp, H.V., Wehrmann, H.A., Larson, D.R., 2011, Meeting east-central Illinois water needs to 2050Potential impacts on the Mahomet aquifer and surface reservoirs: Illinois State Water Survey Contract Report 2011-08, $179 \mathrm{p}$.

Sara, M.N., 2003, Site Assessment and Remediation Handbook, (2nd ed.): Lewis Publishers, Boca Raton, Fla., 1160 p. 
Shapiro, S.D., Plummer, L.N., Busenberg, Eurybiades, Widman, P.K., Casile, G.C., Wayland, J.E., and Runkle, D.L., 2012, Estimates of tracer-based piston-flow ages of groundwater from selected sites - National Water-Quality Assessment Program, 2006-10: U.S. Geological Survey Scientific Investigations Report 2012-5141, 100 p.

Sievers, D.M., Fulhage, C.D., 1992, Survey of rural wells in Missouri for pesticides and nitrate: Ground Water Monitoring Review, v. 12, p. 142-150.

Sokol, Daniel, 1963, Position and fluctuations of water level in wells perforated in more than one aquifer: Journal of Geophysical Research, v. 68, no. 4, p. 1079-1080.

Soller, D.R., Price, S.D., Kempton, J.P., and Berg, R.C., 1999, Three-dimensional geologic maps of Quaternary sediments in east-central Illinois: U.S. Geological Survey Geologic Investigations Series Map I-2669.

Stephenson, D.A., Fleming, A.H., Mickelson, D.M., 1988, Hydrogeology of glacial deposits, in Back, W., Rosenshein, J.S., and Seaber, P.R., eds., Hydrogeology: The Geology of North America, Geological Society of America, Boulder, Colo., v. O-2, p. 301-314.

Stone, W.W., 2013, Estimated annual agricultural pesticide use for counties of the conterminous United States, 1992-2009: U.S. Geological Survey Data Series 752, 1 p. pamphlet, 14 tables.

Thatcher, L.L., Janzer, V.J. and Edwards, K.W., 1977, Methods For determination of radioactive substances in water and fluvial sediments: U.S. Geological Survey Techniques of Water-Resources Investigations, book 5, chap. A5, $95 \mathrm{p}$.

Thatcher, L.L., 1962, The distribution of tritium fallout in precipitation over North America: Lovain, International Association of Hydrological Sciences Publication No. 7, p. $48-58$.

U.S. Environmental Protection Agency, 2014, Chemical details-Molinate: accessed January 16, 2014, at http:// iaspub.epa.gov/apex/pesticides/f?p=CHEMICALSEAR CH:3:983897229922::NO:1,3,31,7,12,25:P3_XCHEMICAL_ID:2916.

U.S. Environmental Protection Agency, 2008, Reregistration eligibility decision for Prometon, March 25, 2008: Office of Pesticide Programs, accessed January 16, 2014, at http:// www.epa.gov/oppsrrd1/REDs/prometon-red.pdf.

U.S. Environmental Protection Agency, 2006a, Interim reregistration eligibility decision-Diazinon: Office of Pesticide Programs, publication number EPA 738-R-04-006 (May 2004), accessed January 2, 2014, at http://www.epa.gov/ pesticides/reregistration/REDs/diazinon_red.pdf.
U.S. Environmental Protection Agency, 2006b, Interim reregistration eligibility decision for Atrazine, Case No. 0062, in: Decision documents for Atrazine: Office of Pesticide Programs, accessed January 2, 2014, at http://www.epa.gov/ oppsrrd1/REDs/atrazine_combined_docs.pdf.

U.S. Environmental Protection Agency, 1996, Reregistration eligibility decision (RED) Trifluralin: Office of Pesticide Programs, publication number EPA-738-F-95-040 (April 1996), accessed January 23, 2014, at http:/www.epa.gov/ oppsrrd1/REDs/factsheets/0001 fact.pdf.

U.S. Environmental Protection Agency, 1995, MetolachlorReregistration eligibility decision (RED) Fact Sheet: Office of Pesticide Programs, publication number EPA738-F-95-007 (April 1995), accessed January 2, 2014, at http://www.epa.gov/oppsrrd1/REDs/factsheets/0001 fact.pdf.

U.S. Environmental Protection Agency, 1984, Guidance for the reregistration of manufacturing-use and certain end-use pesticide products containing Cyanazine (100101), Case number 066: Office of Pesticide Programs (December 1984), accessed February 26, 2014 at http://nepis.epa.gov/ Exe/ZyNET.exe/9100ATX0.TXT?ZyActionD=ZyDocumen t\&Client=EPA\&Index $=1981+$ Thru $+1985 \&$ Docs $=\& Q u e r y=$ $\&$ Time $=\&$ EndTime $=\&$ SearchMethod $=1 \&$ TocRestrict $=$ n $\&$ T $\mathrm{oc}=\&$ TocEntry $=\& Q$ Field $=\& Q$ FieldYear $=\& Q$ FieldMonth $=$ $\& Q$ FieldDay $=\&$ IntQFieldOp $=0 \&$ ExtQFieldOp $=0 \& X m l Q u$ ery $=\&$ File $=D \% 3 \mathrm{~A} \% 5$ Czyfiles $\% 5$ CIndex $\% 20$ Data $\% 5 C 81$ th ru85\%5CTxt $\% 5$ C00000016\%5C9100ATX0.txt\&User $=A N$ ONYMOUS\&Password=anonymous\&SortMethod $=\mathrm{h} \% 7 \mathrm{C}$ \&MaximumDocuments $=1 \&$ FuzzyDegree $=0$ \&ImageQuality $=\mathrm{r} 75 \mathrm{~g} 8 / \mathrm{r} 75 \mathrm{~g} 8 / \mathrm{x} 150 \mathrm{y} 150 \mathrm{~g} 16 / \mathrm{i} 425 \&$ Display $=\mathrm{p} \%$ 7Cf $\&$ DefSe ekPage $=\mathrm{x} \&$ SearchBack $=$ ZyActionL\&Back $=$ ZyActionS\&B ackDesc $=$ Results $\% 20$ page $\&$ MaximumPages $=1 \&$ ZyEntry $=1$ \&SeekPage $=$ x\&ZyPURL\#.

U.S. Geological Survey, 2014, National water information system data available on the world wide web (USGS WaterQuality Data for Illinois), accessed January 14, 2014, at http://waterdata.usgs.gov/il/nwis/qw.

Walton, W.C., 1984, Practical aspects of groundwater modeling: National Water Well Association, Westerville, Ohio, $566 \mathrm{p}$.

Williams, R.E., and Farvolden, R.N., 1967, The influence of joints on the movement of ground water through glacial till: Journal of Hydrology, v. 5, p. 163-170.

Yeskis, D.J., and Zavala, Bernard, 2002. Ground water forum issue paper-Ground-water sampling guidelines for superfund and RCRA project managers: Washington D.C., U.S. Environmental Protection Agency, Office of Solid Waste and Emergency Response, EPA/542/S-02/001, 53 p. 


\section{Tables 4 and 5}




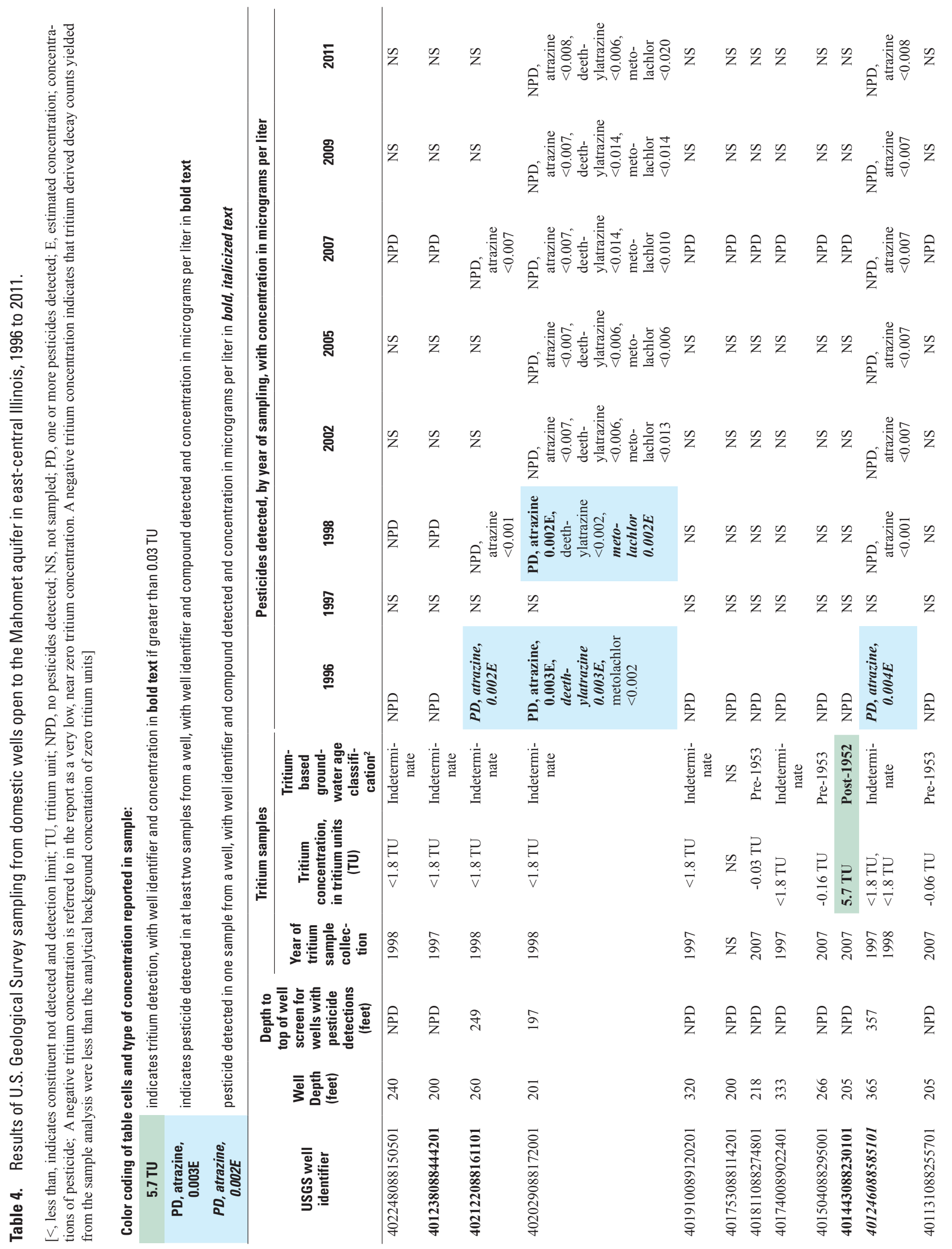


Table $4 \quad 51$
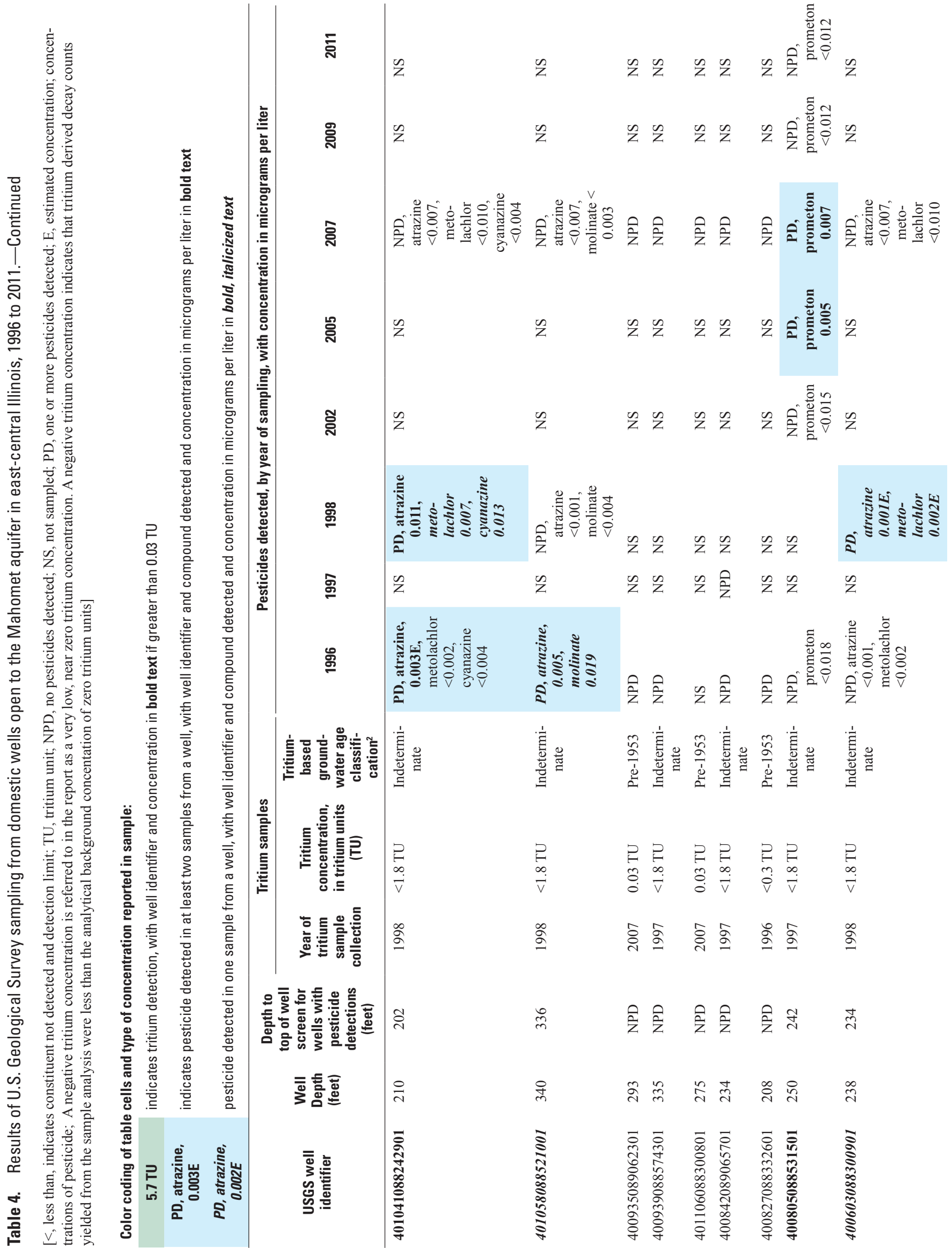

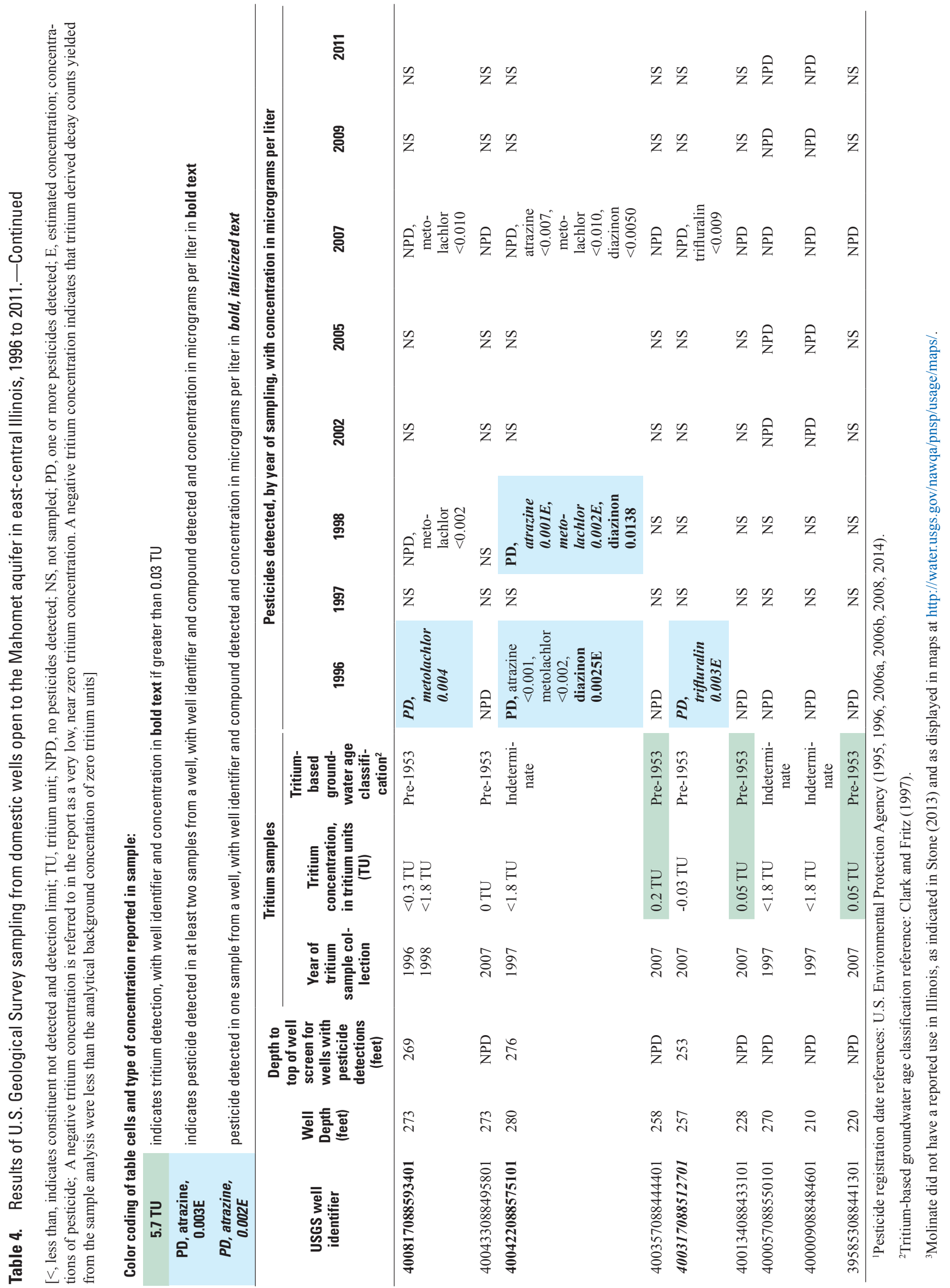

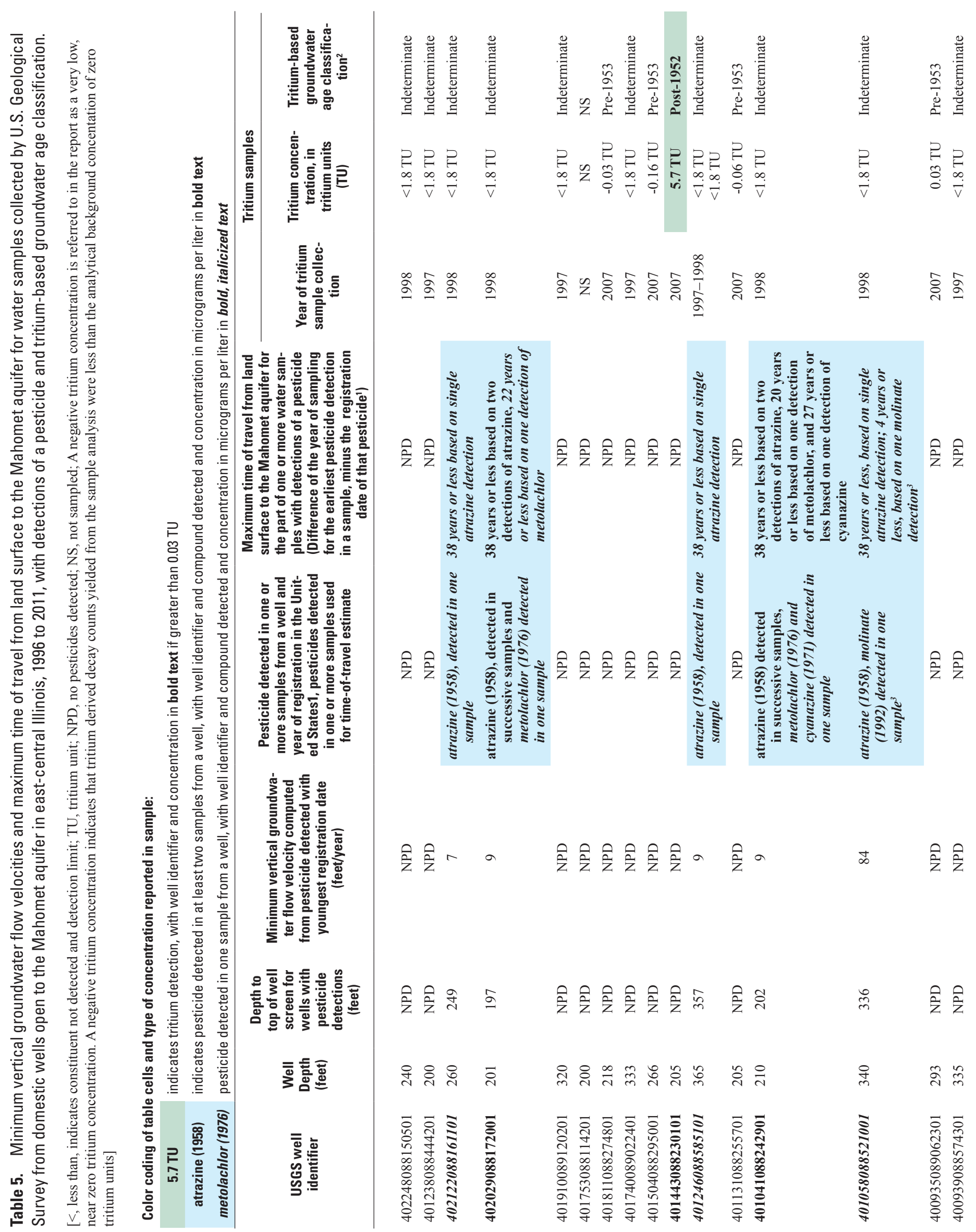

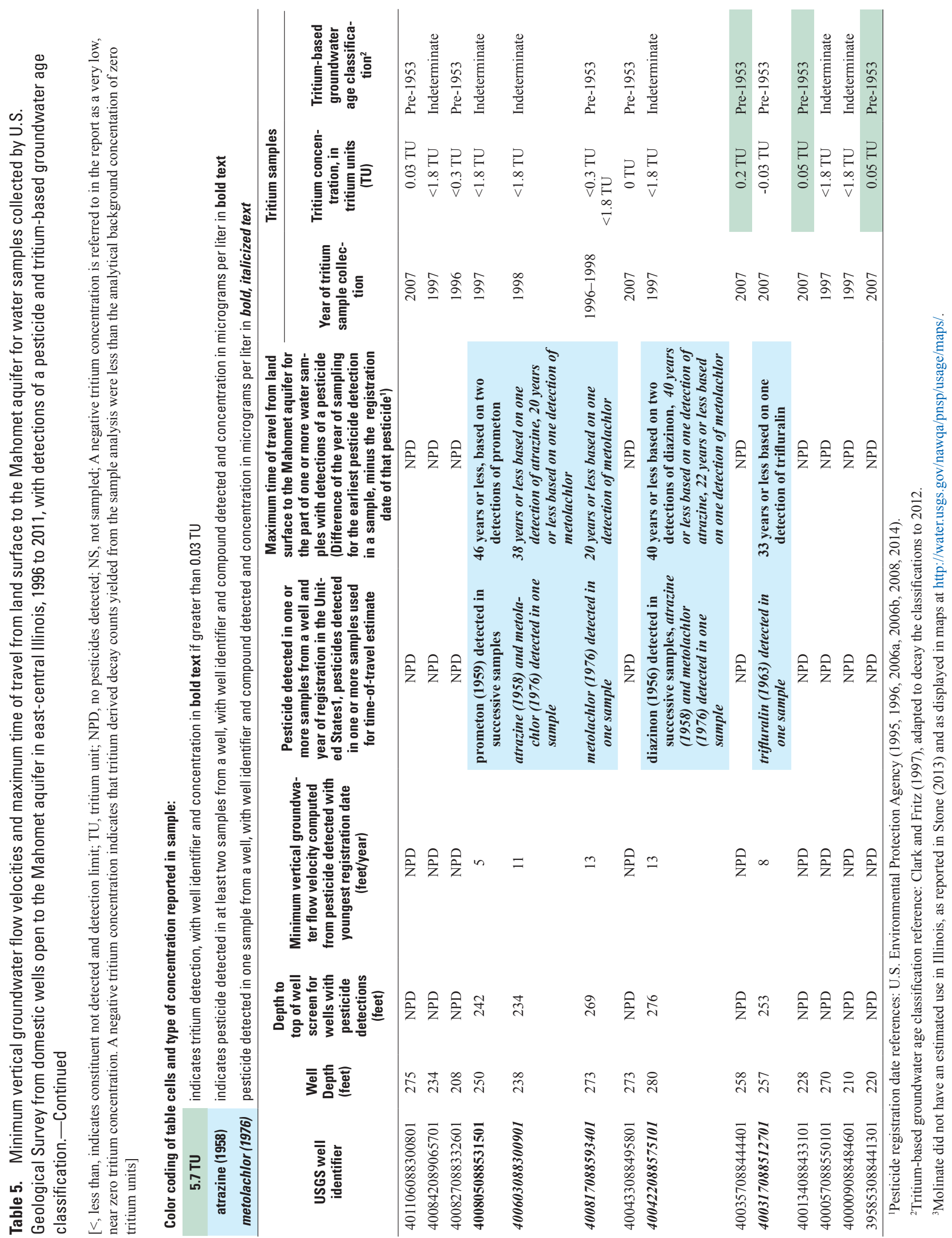
Publishing support provided by the U.S. Geological Survey Science Publishing Network,

Madison and Rolla Publishing Service Centers 




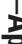

